\title{
The Missoula and Bonneville floods-A review of ice-age megafloods in the Columbia River basin
}

\author{
O'Connor Jim E. ${ }^{1,}{ }^{\text {, }}$, Baker Victor R. ${ }^{2}$, Waitt Richard B. ${ }^{3}$, Smith Larry N. ${ }^{4}$, Cannon Charles M. ${ }^{1}$, \\ George David L. ${ }^{3}$, Denlinger Roger P. ${ }^{3}$
}

1 U.S. Geological Survey, Portland, OR, USA

2 University of Arizona, Tucson, AZ, USA

3 U.S. Geological Survey, Vancouver, WA, USA

${ }^{4}$ Montana Technological University, Butte, MT, USA

*Corresponding author : Jim E. O'Connor, email address : oconnor@usgs.gov

\begin{abstract}
:
The Channeled Scabland of eastern Washington State, USA, brought megafloods to the scientific forefront. A 30,000-km2 landscape of coulees and cataracts carved into the region's loess-covered basalt attests to overwhelming volumes of energetic water. The scarred landscape, garnished by huge boulder bars and far-travelled ice-rafted erratics, spurred $\mathrm{J}$ Harlen Bretz's vigorously disputed flood hypothesis in the 1920s. First known as the Spokane flood, it was rebranded the Missoula flood once understood that the water came from glacial Lake Missoula, formed when the Purcell Trench lobe of the last-glacial Cordilleran ice sheet dammed the Clark Fork valley in northwestern Idaho with ice a kilometer thick. Bretz's flood evidence in the once-remote Channeled Scabland, widely seen and elaborated by the 1950s, eventually swayed consensus for cataclysmic flooding. Missoula flood questions then turned to some that continue today: how many? when? how big? what routes? what processes?

The Missoula floods passed through eastern Washington by a multitude of valleys, coulees and scabland tracts, some contemporaneously, some sequentially. Routings and their timing depended on the positions of various lobes of the multi-pronged Cordilleran ice sheet and the erosional development of the channels themselves. The first floods mostly followed the big bend of Columbia valley looping through north-central Washington. But the south-advancing Okanogan ice lobe soon blocked that path, forming long-lasting glacial Lake Columbia in the impounded Columbia valley. Missoula floods into this lake were diverted south out of the Columbia valley and into eastern Washington coulees and scabland tracts. At least four floods entered Moses Coulee, but then as the Okanogan lobe advanced over and blocked the head of that coulee, more eastern paths took the water, including Grand Coulee and the Telford-Crab-Creek and Cheney-Palouse scabland tracts. Flood routing also depended on the erosion of the coulees. At some point, headward erosion of upper Grand Coulee lowered the divide saddle between the west-running Columbia valley and the deep and wide Grand Coulee heading southwest. Still uncertain is when this happened and the consequences with respect to the stage and extent of glacial Lake Columbia and to flood access to the other, higher, flood routes. Downstream, all flood routes converged into Pasco Basin, flowed through Wallula Gap and the Columbia River Gorge into the Pacific Ocean, following submarine canyons and depositing sediment layers on abyssal plains.
\end{abstract}


Stratigraphic studies indicate dozens-likely more than a hundred-separate Missoula floods during the last glacial period. Over the length of the flood route, backwater areas and depositional basins preserve multiple flood beds, many of which are separated by signs of time, including volcanic ash layers and soil development in subaerial environments; and varve-like beds and pelagic mud layers in lacustrine and marine settings. Evidence also comes from the glacial Lake Missoula basin, where stratigraphy indicates dozens of filling and emptying cycles. Varve counts in conjunction with radiocarbon dating and paleomagnetic secular variation show the repeated filling-and-release cycles of glacial Lake Missoula had intervals possibly as long as 100 years early in the lake's history but diminished to just one or two years for the last few floods. This behavior accords with jökulhlaup-style floods released by subglacial drainage from a self-dumping ice-dammed lake. Not yet clear is whether such a mechanism applies to all the floods or if some emptied more cataclysmically as hypothesized by some.

Radiocarbon dating of sparse organic materials remains key to defining flood chronology but has been lately bolstered by analyses of terrestrial cosmogenic nuclides and optically stimulated luminescence. Varve counts and paleomagnetic secular variation studies help to define durations and intervals represented by sequences of flood beds. The $\sim 16$ ka Mount St. Helens Set S tephra is commonly interbedded within flood deposits, enabling correlation of deposits among sites. Tephra from the 13.713.4 ka eruption of Glacier Peak overlies all glacial Lake Missoula and Missoula flood deposits, defining an end time. Overall conclusions are that glacial Lake Missoula was extant and producing floods for at least 3-4 ky during 20-14 ka. At least 75 floods preceded Mount St Helens Set S, followed by 30 or more after the tephra fall. Most floods entered glacial Lake Columbia, impounded by the Okanogan lobe, for 2-5 ky between about 18.5 and $15 \mathrm{ka}$. Glacial Lake Columbia outlived Lake Missoula by >200-400 yr but may have been born later since at least one flood came down the Columbia valley before the Okanogan ice lobe blocked the Columbia valley at 18.5-18 ka. The maximum extent of the Okanogan and Purcell Trench lobes, many Missoula floods, substantial erosion of upper Grand Coulee, and the widespread tephra falls from Mount St. Helens eruptions all happened about 17-15 ka. People, in the area since $16.6-15.3 \mathrm{ka}$, almost certainly witnessed the last of the Missoula floods and later large floods from other ice-dammed lakes in the Columbia River basin.

Quantitative flow analyses give peak discharge estimates and support understanding of erosional and depositional processes. The first flow assessments were simple cross-section calculations but recent assessments employ two-dimensional hydrodynamic models. The general finding is that emplacement of the maximum stage evidence requires about 20 million m3/s near the Lake Missoula outlet and about 515 million m3/s through Wallula Gap and downstream in the Columbia River Gorge. These hydraulic analyses raise still-unresolved questions regarding canyon erosion and possible additional water sources.

The large Pleistocene Bonneville flood entered the Columbia River system from the southeast from pluvial Lake Bonneville, the Pleistocene predecessor to Great Salt Lake in the eastern Great Basin. During the last glacial, the lake basin filled, covering $>50,000 \mathrm{~km} 2$ with $10,400 \mathrm{~km} 3$ of water before reaching its maximum possible stage governed by Red Rock Pass, the lowest divide separating the basin from the Snake River basin to the north. The overtopping lake rapidly incised 108-125 m into the Red Rock Pass outlet, spilling half of its total lake volume. G.K. Gilbert described the essential sequence in the 1870 s, but the flood was mostly forgotten until the late 1950s when Harold Malde linked the spectacular scabland topography and bouldery "melon gravel" on the Snake River Plain to the Lake Bonneville overflow. The Bonneville flood appears to have been a singular event at about $18 \mathrm{ka}$. No evidence of multiple or prelast-glacial spillovers has yet been found. Its total volume was about twice that of a maximum Lake Missoula flood yet its peak discharge was $\sim 1$ million $\mathrm{m} 3 / \mathrm{s}$, less than a tenth of the largest Missoula floods. Its comparatively simple flow path and much steadier flow make the Bonneville flood ideal for new studies of erosional and depositional processes.

At least two floods seem to have passed down the Columbia valley after the last of the Missoula floods, including a large flood about $\sim 14$ ka likely from cataclysmic demise of the thinning Okanogan ice lobe dam impounding glacial Lake Columbia. Floods from earlier glacial ages left scant yet clear evidence in the Channeled Scabland and Columbia valley. But their source, timing, and magnitudes are little understood. Some deposits are paleomagnetically reversed, thus older than $\sim 800 \mathrm{ka}$. Last-glacial floods 
and perhaps older ones affected the Snake River Plain, some likely sourced in lakes dammed by alpine glaciers in central Idaho.

Keywords : Megafloods, Columbia River basin, western North America, Missoula Floods, Bonneville Flood, Channeled Scabland 


\section{Introduction}

\section{Ice-age Floods of the Columbia}

Megaflood science gained early traction in the Columbia River basin . : western North America (Figure 1). The terrain has nourished and stretched thinking about lanc scap : formation and geologic processes for more than 100 years, led by prominent geologists sac: ac G.K. Gilbert, J Harlen Bretz, Richard Foster Flint, and Harold Malde. It has stirred contre rers by inspiring new ideas and challenging old ones. It still gives rise to fresh ideas, now being apr $1:-\gamma$ to megaflood-carved terrains worldwide and on other planets (Baker, 2009, 2020). Here we revie . the ice-age megafloods of the U.S. Pacific Northwest, their history of discovery, current un rstanding, and outstanding questions. The focus is the late Pleistocene Missoula floods and the sna $\mathrm{cm}^{-}$ular Channeled Scabland, but similar in extent and geomorphic record is the Bonneville fin t in pluvial Lake Bonneville in the Snake River drainage.

Figure 1. Overview map of U.S. Pacı" - Ne "thwest megaflood landscape. Bonneville flood inundation modified from O'Connor (1993); Missoula flood ; . "du.' n courtesy of Daniel Coe, Washington Geological Survey; maximum extent of Cordilleran ice sheet and adjac. "t _....iers based on Waitt and Thorsen (1983), Booth (1986), Clague (1989), Locke (1995), Carrara et al. (1996), Smith (2乞. ., Riedel (2017), and unpublished mapping by Ralph Haugerud, U.S. Geological Survey. Extent of Bonneville flood downstream of Lewiston is within Missoula flood extent.

We begin with a short history of flood research in the Columbia River basin. We then describe the two major but overlapping megaflood landscapes: the Bonneville flood chiefly along the Snake River and the Missoula floods and the Channeled Scabland within the Columbia drainage. We summarize their causes, routes, and timing, as well as new questions and opportunities. We conclude with brief comments on 
other large last-glacial floods in the region, floods from prior ice ages, and the possibility that people witnessed some of the Columbia Basin megafloods.

\section{A Difficult Birth}

The first written recognition of cataclysmic flooding in the U.S. Pacific Northwest may reside in G.K. Gilbert's field notes for Aug. 16, 1876, inked as he approached the north margin of pluvial Lake Bonneville in northern Utah (Hunt, 1982; O'Connor, 2016). Arriving at the Red Rock Pass outlet, Gilbert wrote "The red rock is only one of a number that are here exceptionall. har 1 , in testimony to the stream that has washed them in degrading this pass." His 1890 monograph su tes "the outpouring was a veritable débâcle” (Gilbert, 1890, p. 175). Yet the Bonneville flood was lo + for some 80 years until resurrected by Harold Malde $(1960,1968)$, in part inspired by the then-recen - unsensus that the Channeled Scabland of eastern Washington was indeed the product of huge Pli ir cor ene floods.

Better known is the "Great Scablands Deba " e" ieaturing J Harlen Bretz (Baker, 1978a, 1981, 2008, 2009; Gould, 1978, 1980). Though not a par tigm shifter like plate tectonics, it exemplifies how science really works. Instead of colorless collerting $r$ facts and observations and unbiased working hypotheses, it involves people - sometimes gang - $w^{*}$ th personalities, agendas, and egos. This was, and maybe still is, the case for the Channeled Scac ${ }^{1}$ ?nd

In 1922, Bretz, a 39-ye a -old assistant professor at the University of Chicago, began a series of eight field seasons in eastern Washington State. His first paper (Bretz, 1923a) described eroded scabland tracts, streamlined loess hills, and stratified gravel, ascribing them to a "great flood" (p. 588). His second paper later that year elevated the flood to a "debacle" (Bretz, 1923b, p. 649). But unlike Gilbert’s débâcle 33 years earlier, which remained hardly noticed (O’Connor, 2016), Bretz's advocacy of what he at first called the Spokane Flood provoked weighty resistance.

Most aggressive were the scientists of the U.S. Geological Survey (USGS), culminating in the 1927 meeting of the Geological Society of Washington (Bretz, 1927a; Baker, 2008). Senior USGS scientists 
such as William C. Alden (head of the Pleistocene Division), James Gilluly, Oscar Meinzer, and Edwin T. McKnight ganged up on Bretz. Objections were many; some minor and easily refuted, but tougher were (1) the yet undefined source of water and (2) the rapid and widespread erosion by a single flood. The first point was valid, though the likely flood source—glacial Lake Missoula—was already pointed out by USGS geologist Joseph T. Pardee (Baker, 1995; Baker, 2008, p. 39). But objections focused on the outsized scale of the flood and its effects were dogmatic rather than scientific. The relative new science of geology, and especially the cautious USGS scientists at the meeting, woxked from a notion of uniformitarianism conflating the valid application of modern process s. $\mathrm{ui}^{\mathrm{*}} \mathrm{s}$ ior understanding the past with a narrower presumption that only observed modern processe: anc rates applied to past events (Baker, 1998). This view denied cataclysms like Bretz's Spokane Flord

The controversy continued through the 1930s though $\mathrm{R}_{1}$ etz hau mostly moved to other topics. Richard Foster Flint, prominent on the Yale faculty, was $1 \mathrm{ln}^{1}$ 'st, vut others chimed in alternative hypotheses, such as Edwin T. Hodge (Oregon State University aı. ${ }^{\top}$ University of Oregon) and Ira S. Allison (Oregon State University). Flint, later known as the "Pope o. the Pleistocene" (Goudie, 2008, p. 463), may have had an axe to grind: Bretz had sat on Flint's 1,25 Taiversity of Chicago Ph.D. examining committee and voted to fail Flint (Baker, 2008, p. 41; J I. Bretz written communication with V.R. Baker). Flint, whatever the motive, went after the catastron : r rature of Bretz's hypothesis, proposing instead that the scabland channels were cut slowly :v _ wsurely streams with normal discharge" and that Bretz's flood bars were simply unpaired terraces (Flint, 1938, p. 471). Flint (1938, p. 492) also called upon the scabland flanking the Snake River Canyon in southern Idaho, now known eroded by the Bonneville flood (Malde, 1968), as evidence that such terrain did not require "unusual floods." Hodge (1934) offered a complicated story of long-term drainage integration and multiple glaciations such that the "progress of the work was slow and involved many repeated attacks...over hundreds of thousands of years...[by] common and usual methods that one may see at work today...." Allison (1933, p. 676-677) acknowledged evidence of high water stages but also objected to the catastrophic aspect. He suggested a downstream blockage diverting water 
into upland channels, thereby providing a mechanism that "does not require a short-lived catastrophic flood but explains the scablands, the gravel deposits, diversion channels, and divide crossings as the effects of a moderate flow of water, now here and now there, over an extended period. It thus removes the flood from the "impossible" category." Catastrophes remained the enemy.

Debate was still strong in 1940 when the American Association for the Advancement of Science met in Seattle. A series of papers in a session on the "Quaternary Geology of the Pacific Northwest" piled on to the objections for a catastrophic flood. But late in the session, USGS $\varepsilon$ ologist Joseph Pardee presented a paper titled "Ripple marks (?) in glacial Lake Missoula." He describ 'd ev dence for extraordinary currents in the basin of glacial Lake Missoula, at its largest, a $25^{n} \mathrm{C}^{1} \mathrm{~m}^{3}$ lake dammed $650 \mathrm{~m}$ deep by a lobe of the Cordilleran Ice Sheet. These currents he ascribed io ra jid drainage following failure of the ice dam. Left unsaid at the meeting and in the ensuing paper (Fardee, 1942) was the fate of all that water. The implications were not lost, however, on participants ff a post-meeting day in the scablands with Flint. Much of Flint's evidence for "leisurely streams" was instead interpreted by trip participants as cataclysmic flood features (Baker, 2008; How `rd Meyerhoff, trip participant, 1978 written communication with V.R. Baker).

Bretz cemented the cataclysm:- th od hypothesis with a season of fieldwork in the Channeled Scabland in 1952 (Bretzet 1., 950). Bretz, with colleagues H.T.U. Smith and George Neff, examined many new exposures, asses` ng many possible explanations. Adding new and compelling support were aerial photographs showing broad fields of giant current dunes on gravel bar surfaces - like those left in the basin by draining glacial Lake Missoula. The rippled bars could not be terraces. With the link to glacial Lake Missoula now established, the floods became the Missoula floods. By this evidence most of the geologic community was swayed. The Missoula floods carved the Channeled Scabland, making it into most textbooks (including a sentence in Flint's 1971 "Glacial and Quaternary Geology"). Bretz won the Geological Society of America's 1979 Penrose Medal. Channeled Scabland debates moved onto other questions such as when? how many? how big? 
Why did the scabland debate last 40 years? Not because of lack of evidence. Most pertinent observations were made and reported by 1930 - although aerial photography and discovery of the giant current dunes added new information in 1956. Bretz was ornery; Flint was powerful and may have held a grudge. Catastrophic floods were "impossible" to ruling parties of the North American Pleistocene.

Nevertheless a flood cause for the scablands ultimately prevailed. This in turn guided Malde's (1960, 1968) identification of Bonneville flood features downstream of Red Rock Pass. More work in the scablands a few years later (Baker, 1973) at the time of the Mariner 9 ph^`ographs of Mars inspired recognition of Martian megafloods (Baker and Milton, 1974; Baker, 1 182). Cataclysmic floods are now broadly embraced as a universal shaper of landscapes (Baker, 2013,

\section{The Bonneville Flood}

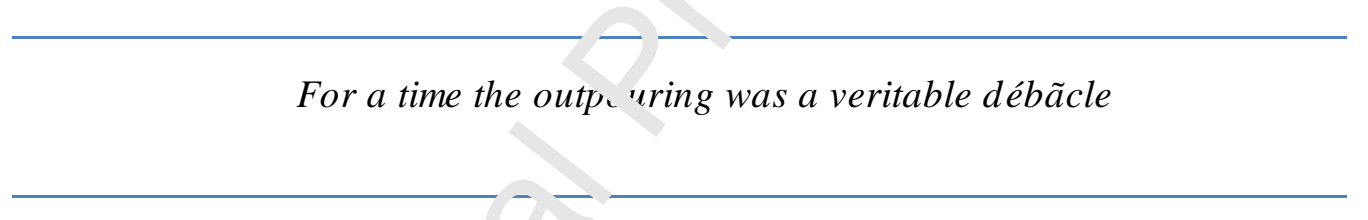

Gilbert (1890, p. 175)

The first discovered ice-age fla 1 in the U.S. Pacific Northwest was the largest in terms of total flood volume- the Bonneville flc od

\section{Pluvial Lake Bonneville}

Pluvial Lake Bonneville was the largest lake in western North America to release a megaflood during the last glacial maximum. Lake Bonneville, Pleistocene predecessor to Great Salt Lake, filled a closed tectonic basin west of the Wasatch Range with more than $10,000 \mathrm{~km}^{3}$ of water, covering $52,000 \mathrm{~km}^{2}$ of western Utah (Table 1; Figure 1). The history of pluvial Lake Bonneville, first comprehensively treated by Gilbert (1890), is thoroughly reviewed in the recent volume edited by Oviatt and Shroder (2016). During its most recent growth cycle beginning about $30 \mathrm{ka}$, the lake haltingly rose until about $18 \mathrm{ka}$, 
when it reached the lowest divide saddle separating it from the Snake River basin to the north. At the crest of an alluvial fan astride the head of Marsh Creek valley just north of Red Rock Pass, the lake stabilized at its maximum Bonneville level of $1552 \mathrm{~m}$ above sea level $^{1}$ and formed the prominent Bonneville shoreline (Oviatt and Jewell, 2016). Overflow at the outlet initiated erosion and catastrophic outflow (Gilbert, 1890) — the débâcle of the Bonneville flood. Lake level dropped, stabilizing 108-125 m lower upon reaching bedrock at Red Rock Pass, releasing about 5135-5320 $\mathrm{km}^{3}$ of water (Miller et al., 2013, p. 360; Adams and Bills, 2016, p. 160; Abril-Hernández et al, 2018, p. 7). The lake remained close to this rock-controlled Provo level for about 3 ky before shrinking to closed-r asi cunditions when climate dried at the end of the Pleistocene.

Table 1. Columbia Basin megaflood-related lakes and transient impo ndm. nt stages; depths, areas, and volumes.

\section{The Flood Route}

Effects of the Bonneville flood are traceat $~ \mathrm{fo}$ more than $1100 \mathrm{~km}$ down the Snake River drainage (Figure 2). From Red Rock Pass it flowed $n$ rth down Marsh Creek into the Portneuf River valley (Figure 3a, b). An immense boulder fan marks the lo' d's entrance onto the Snake River Plain near Pocatello before gathering into canyons of th. St. ke River (Trimble and Carr, 1961). The flood followed the vast and incised Snake River Plain vest ’or 500 km, descending steeply through narrow canyon segments, particularly the $100 \mathrm{~km}$ 'ror ' ea $i$ of Twin Falls to Hagerman (Malde, 1968; O’Connor, 1993). In this steep reach the canyon fill $d$ and the flood split, most flow broadly crossing the uplands north of the Snake River, reentering at several spectacular cataracts and blind canyons eroded into the north canyon rim near Twin Falls (Figure 3c). Deposits of "Melon Gravel" fill canyon expansions and side valleys (Figure 4; Malde and Powers, 1962, p.1216-1217).

\footnotetext{
${ }^{1}$ All reported elevations are relative to the National Geodetic Vertical Datum of 1988 and are modern positions. Many Pleistocene landform elevations were affected by isostatic deformation owing to loading by water and ice.
} 
Figure 2. Profile of the Bonneville flood. Modified from O'Connor (1993, p. 11). Kilometer 0 equivalent to Snake River Mile 140.

Figure 3. Erosion by the Bonneville flood. (a) Aerial view east and upstream in the Portneuf River valley, floored by flooderoded basalt flow. Photograph by Jim E. O'Connor. (b) Ground view of fluted and polished Portneuf Basalt near the scabland in (a). Shovel handle $0.5 \mathrm{~m}$. Photograph by Jim E. O'Connor. (c) Aerial view west and downstream from near Twin Falls, showing scabland and cataracts of the Devils Corralarea carved by flow from the Eden Channel reentering the Snake River Canyon near Snake River Mile 617. Photograph by Bruce Bjornstad.

Figure 4. Deposits of the Bonneville flood. (a) View downstream of immense boulder - rr partly filling $1.5 \mathrm{~km}$ wide canyon downstream of the Swan Falls constriction near Snake River Mile 457. (b) Close vien of be. 'load on the bar in (a). Many clasts have long diameters exceeding $10 \mathrm{~m}$. (c) View north (downstream) in Hells Cany $n$ nec $r$ Snake River Mile 227, showing immense point bar (with large Ponderosa Pines along river edge) and flood-swept valloy.'ope to nearly 200 m above. (d) Sand and fine gravel deposited from suspended load in an eddy bar east of Hagerman, Ia. '" 'in ick is $0.7 \mathrm{~m}$ long. (e) Horizontally bedded Missoula Flood deposits on top of foreset bedded Bonneville Flood grr vel in the Tammany Creek valley near Lewiston, Idaho, Snake River Mile 146. Here about 20 Missoula flood beds wore. 'ft by that number offloods backing up the Snake River (Waitt, 1985a). The foresets in the Bonneville Flood gravel dip $u_{t} T$ ،mmany Creek valley, indicating up-valley flow as the bar formed. Photographs by Jim E. O'Connor

After spreading out at the west end \& $f$ tl a snake River Plain, the flood followed the Snake River north and at Farewell Bend entered conf: ed valleys leading to the deep and constricted Hells Canyon (Figure 2; Figure 4c). Here the flood boı' er oded and deposited gravel more than $175 \mathrm{~m}$ above present river level (Figure 4c; O’Connor, 1५,3). Iunneville flood deposits extend north to Lewiston (Figure 4e), and follow the deep Snake River canyon west. The most downstream Bonneville flood deposits yet found are $40 \mathrm{~km}$ west of Lewiston at Snake River Mile 103 (Kurt Othberg, Idaho Geological Survey, unpublished mapping). Downstream deposits of the Bonneville flood become progressively buried by Missoula flood beds (Figure 4e), masking their distribution, particularly below the Palouse River confluence at Snake River Mile 60, where huge bars of Missoula flood gravel partly fill the Snake River canyon. 


\section{A Singular Flood}

The release of the upper 108-125 m of pluvial Lake Bonneville was a one-time event. The distinctly weaker Marsh Creek alluvial sediment compared with the underlying bedrock led to run-away erosion of the outlet until stopped by the harder rock (Gilbert, 1890, p. 175, Abril-Hernández et al., 2018; GarciaCastellanos and O'Connor, 2018). The lake remained at the Provo level until evaporation exceeded flow into the basin $\sim 3$ ky later, starting closed-basin conditions culminating in modern Great Salt Lake. No evidence has yet been found of overflows into the Snake River basin dur..r earlier lake cycles—neither flood evidence in the Snake River Plain nor older high shorelines in th Br.neville basin. Bear River, draining mountain ranges east of Lake Bonneville, diverted into he n nneville basin at 60-50 ka, drainage that accounts for most inflow into the basin (Pedei in e al., 2016); hence the last-glacial lake cycle was likely the highest ever (Bright, 1963).

\section{Flood Timing}

The age of the Bonneville flood is mos' sec 'rely known by the radiocarbon chronology of pluvial Lake Bonneville. Oviatt's (2015) ana's. Jwe Lake Bonneville reaching peak level at or after $18.4 \mathrm{ka}^{2}$ but dropping to the Provo level bel re 1\%.1 ka. He concludes "a reasonable age near the middle of the overlapping range is $18 \mathrm{ka}$ with a n ncertainty of several hundred calibrated years.” Miller (2016, p. 135137) interprets recent Pro $>$ suureline age information as indicating an 18.3-18.2 ka age for the Bonneville flood. These ages are consistent with some cosmogenic dates from flood-transported boulders (Amidon and Clark, 2015) and flood-eroded basalt (Lamb et al., 2008, 2014; Amidon and Farley, 2011). For example, cosmogenic ${ }^{3} \mathrm{He}$ and ${ }^{21} \mathrm{Ne}$ ages of five flood-transported basalt clasts $50 \mathrm{~km}$ downstream of Red Rock Pass give a combined result of 17.5 \pm 0.9 ka (Amidon and Clark, 2015).

\footnotetext{
${ }^{2}$ All radiocarbon ages are reported in 1000 s of calendar years before present, ka, referenced to 1950 AD. Unless otherwise noted, if not calibrated in the source literature we have calibrated specific age results using the IntCal 13 radiocarbon age calibration curve (Reimer et al, 2013) implemented by OxCal 4.3 (Bronk Ramsey 2009; https://c14.arch.ox.ac.uk/OxCal/OxCal.html) and report the resulting two-standard-deviation confidence range of the calibration of the radiocarbon age and its original counting-error uncertainty.
} 


\section{Flood Magnitude and Duration}

Estimates for the size of the Bonneville flood go back to Gilbert's (1890, p. 177) assessment that it was "the flood volume of the Missouri" (Table 2) - about 20,000 $\mathrm{m}^{3} / \mathrm{s}$ in Gilbert's time (O'Connor, 2016). Discharge estimates have since escalated, peaking at about 1 million $\mathrm{m}^{3} / \mathrm{s}$ by O’Connor's (1993) assessment of peak discharge near the outlet. This estimate, as well as Jarrett and Malde's (1987) determination of $0.7-1.0$ million $\mathrm{m}^{3} / \mathrm{s}$ farther downstream near Swan Falls are both consistent with recent hydrodynamic modeling of flow through the eroding outlet that indicates 5 ak outflow of 0.85 million $\mathrm{m}^{3}$ /s (Abril-Hernández et al., 2018). This new modeling also indicates 'Itf' Jw at Red Rock Pass exceeded 0.5 million $\mathrm{m}^{3} / \mathrm{s}$ for $\sim 17$ days. Lapôtre et al. (2016) re': te .....erfall erosion by block toppling to the geometry of amphitheater-headed canyons_-like the cat ; act: of the Devils Corral complex shown in Figure $3 \mathrm{c}$ - to predict formative flow conditions. For e cil of two such canyons along the Bonneville flood route they (p. 1249, 1252) estimate canyo ${ }^{*}$ ' a $^{\prime}$ ' veak discharges of about $5000 \mathrm{~m}^{3} \cdot \mathrm{s}^{-1}$ and a duration of 30 days. Because these canyons carrı 1 just a small portion of the overall flood volume, these

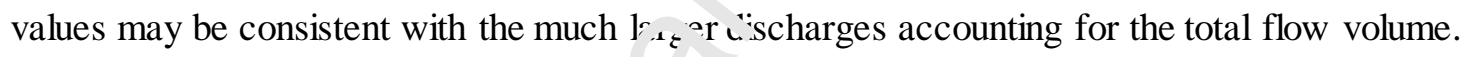

Table 2. Columbia Basin megaflood disc., 'rge єstimates.

\section{Bonneville Flood Questio.ns cnd Opportunities}

Because it was a single 1 . od chiefly following a single-channel route, the Bonneville flood provides a superb opportunity for understanding megaflood processes. High-resolution digital topography in conjunction with high-resolution hydrodynamic modeling and fine-scale mapping of flood features could vastly improve understanding of the linkages between flow conditions and erosional and depositional processes. As listed by O'Connor (2016), such analysis could address megaflood questions and issues of broad interest:

- What are the thresholds and processes of bedrock-channel erosion for different rock types and different hydrodynamic environments? This question has been tackled for the Red Rock Pass 
outlet (Garcia-Castellanos and O’Connor, 2018) and for some of the amphitheater-headed canyons (Lapotre et al., 2016) but could be assessed at other locations.

- What situations lead to canyon incision instead of widening? And at what rates?

- How do alcoves and cataracts form and develop in the layered basalt flows? The toppling mechanism proposed by Lapotre et al. (2016) is one plausible explanation, but others might be viable as well.

- What are the main controls on sediment transport and depositir i1! Wulat is the fate of floodtransported sediment? How does deposit stratigraphy relat to ‘'ow dynamics?

Besides such general megaflood process questions, topic mo : specific to the Bonneville flood merit further study. These include analysis of the processes in : ing the canyon near Massacre Rocks in the eastern Snake River Plain (Figure 2), probably formı t enurely during the flood (Scott et al., 1982). Similarly, the narrow canyon reach east of Tw1t alls, now descending steeply by tall drops and knickpoints like Shoshone Falls, may have lat ${ }_{c}$ ly or entirely formed during the flood. Farther downstream and in a very different ge jo oi environment is steep and narrow Hells Canyon. How much did the Bonneville Flood contributt ${ }^{\circ} \mathrm{o}$ its present morphology and depth?

\section{The Missoula Fliors}

To understand the scabland one has to throw away textbook treatments of river work.

—J. Hoover Mackin, as quoted in Bretz et al. (1956, p. 960)

The Missoula floods may be the best known megafloods on Earth. Their early discovery and ensuing controversy, the exposure and accessibility of spectacular flood features in arid eastern Washington, and 
the reams of literature — books, scientific journals, park brochures, creationist manifestos—-has inspired all types of investigation, exploration, and explanation. The Channeled Scabland continues to be a source of knowledge and amazement regarding planetary landscapes. The flood geography and geology are complex, however, derived from diverse interactions among the Cordilleran ice sheet, ice-dammed lakes, and available flow pathways through the rumpled Pacific Northwest landscape. We first describe the geography, features, and key interactions for the glacial lakes and various flood routes, and then summarize current understanding of timing, the number, and sizes of floods. Along the way, we identify key uncertainties and questions needing more study.

\section{The Cordilleran Ice Sheet and Ice-Dammed Lakes}

During the last glacial period, ice from the Cordilleran ice ' '_et advanced south from the Canadian Coast Mountains and Rockies in lobes channeled dow $1 r_{\text {.10 }}$ ntain valleys, setting the stage for the Missoula floods by deranging (and augmentins, dr inaze (Figure 1, Figure 5; Waitt et al., 2016). The ice lobes of most influence were the Purcell T: anch lobe that dammed glacial Lake Missoula, the Columbia lobe descending the Columbia valley anc $b^{1} x^{1}$;ing the Spokane valley; and the Okanogan lobe that blocked the Columbia River at its big hena between Grand Coulee and Chelan.

Figure 5. Map of Channeled Scal. ^nd s owing approximate last-glacial-maximum extent of Cordilleran Ice Sheet, major flood pathways, and approxi 'ate Missc ula flooding extent. Glacial Lake Columbia depicted at maximum plausible $730 \mathrm{~m}$ elevation; glacial Lake Spokane at $500 \mathrm{~m}$.

\section{Purcell Trench Lobe and Glacial Lake Missoula}

A thick ice lobe streamed south from the Rocky Mountains, following the Purcell Trench (Figure 1, Figure 5, Figure 6). The lobe entered and filled the deep basin now occupied by Lake Pend Oreille, its southern edge abutting the steeply rising Bitterroot Range to the south, blocking the Clark Fork River from its northwestward course. Near where the Clark Fork River enters Lake Pend Oreille, the upper limit of ice was above $1350 \mathrm{~m}$ (Waitt et al., 2016), more than $700 \mathrm{~m}$ above the modern valley bottom and 
implying ice a kilometer thick over the 350-m-deep (Fields et al., 1996) basin of Lake Pend Oreille. At its maximum, an ice lobe branched southeast, pushing southeast and up the narrow Clark Fork valley for perhaps $80 \mathrm{~km}$ (Breckenridge et al., 1989, p. 15-16).

Figure 6. Hypothesized Missoula-flood scenarios involving interactions with glacial Lake Columbia and the major flood pathways. Modified from Waitt (2016) and Balbas et al. (2017). Timing approximate and summarizes information presented in text. Not shown are possible interactions involving the Columbia lobe blocking the Spokane River and resulting glacial Lake Spokane. (a) Key geographic elements. A and A' show end-points of profile of Figure 8. (b) Glacial Lake Missoula forms and first Missoula flood(s) pass down Spokane River and Columbia River valleys. (c) Okanos ‘ lobe blocks Columbia Valley, impounding glacial Lake Columbia and shunts at least four Missoula floods south int Mos s Coulee (Waitt, 1985a, 2016, in press). (d) Maximum Okanogan lobe ice extent, blocking entrance to Moses Couı e anc possibly Grand Coulee, and raising glacial Lake Columbia to $715-730$ m.. (e) Retreated Okanogan lobe still $h^{\text {t }}$-ks Solumbia River, maintaining glacial Lake Columbia, but now lowered and stabilized by a Grand Coulee outlet at 510- - 5 , m level (map shows $520 \mathrm{~m}$ ). (f) Possible lastglacial incision of upper Grand Coulee threshold to modern threst, ld el ’vation of $470 \mathrm{~m}$ lowers glacial Lake Columbia. Glacial Lake Columbia persists for at least another 200-400 years . ${ }^{4}$ or $\therefore$ : last Missoula flood (Atwater, 1987, p. 185-187) before possibly cataclysmically breaching its ice dam, sending $a_{,}{ }^{7}, \mathrm{~d}$ down the Columbia Valley downstream of the Okanogan River confluence.

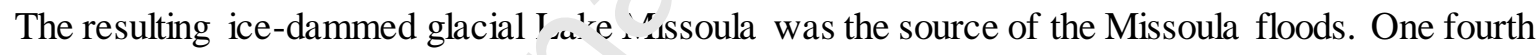
the volume but twice the depth of $\mu$. 'vial Lake Bonneville (Table 1), Lake Missoula formed (and reformed) in the Clark Fork Rivc - $h_{\curlywedge}$ sin of northern Idaho and western Montana. Hemmed in by tall valley walls everywhere a. diu by Cordilleran ice sheet lobes and alpine ice to the east, the water rose behind the ice dam, filling the deep and tortuous valleys of the Clark Fork River and the tributary Flathead River (Pardee, 1910, 1942). Once rising to a critical elevation to destabilize the blocking ice, drainage ensued, many times catastrophically. At its maximum elevation of $1295 \mathrm{~m}$, evident from shorelines etched into Mount Jumbo just east of Missoula, the lake covered 10,700 km², held about 2500 $\mathrm{km}^{3}$ of water, and was $650 \mathrm{~m}$ or more deep at the ice dam (Figure 7a; Figure 8). From stratigraphic records in the Missoula lake basin (Chambers, 1971, 1984; Waitt, 1980, 1985a, Smith, 2006; Hanson et al., 2012), and downstream (Glenn, 1965; Waitt, 1980; 1984, 1985a; Atwater, 1984, 1986, 1987; Smith, 
1993; Clague et al., 2003; Benito and O’Connor, 2003), lake releases apparently recurred dozens of times; each time followed by renewed damming by the south-flowing ice lobe. Not clear is how many times glacial Lake Missoula approached it maximum level, but stratigraphy at Garden Gulch, Montana, shows 7-12 late Pleistocene lake-level fluctuations above $1170 \mathrm{~m}$, representing at least $\sim 65 \%$ of its maximum volume (Smith, 2017, Smith et al., 2018). The Purcell Trench lobe apparently reoccupied the Lake Pend Oreille basin after the last catastrophic release of glacial Lake Missoula, rimming the southern end of Lake Pend Oreille with an uneroded moraine (Smyers and Breckenridge 2003, p. 13).

Figure 7. Glacial Lake Missoula features. (a) View northwest toward Missoula a 1 Cla $k$ Fork River Valley from near the summit of 1570 m Mount Sentinel, showing glacial Lake Missoula shorelines etcl od as high as 1295 m on flanks of Mount Jumbo. Photograph by Brennan D. O'Connor. (b) Ninemile stratigraphic sertio. oxposed along eastbound lanes of I-90, where multiple varved sequences separated by sand and silt beds signal dozens o, $\mathrm{I}_{\mathrm{r} r}$ aings of glacial Lake Missoula (Alt and Chambers, 1970; Chambers, 1971, 1984; Waitt, 1980, 1985a, Smit „, L ‘06; Hanson et al., 2012). The top of the section is at 959 m. Photograph by Jim E. O'Connor. (c) Grass-covered Ston's ; rr, one of many high eddy bars described by Pardee (1942, p. 1589-1593) filling tributary valleys and gulches flanking ho Clark Fork and Flathead River valleys, which became major flow conduits during lake drainage. The top of the deposu * at $1000 \mathrm{~m}, 230 \mathrm{~m}$ above modern river level; flow was from right to left. Photograph by Jim E. O'Connor.

Figure 8. Profile of key topographic, glacic, ar. 'flood features along $600 \mathrm{~km}$ of the Missoula flood route between Wenatchee, Washington, and the lower Clark Fork Riv、 "valley, Idaho and far western Montana. Endpoints shown as A and A'on Figure 5. Modern digital elevation profile, ‘clun."ng modern reservoir surfaces, extracted from U.S. Geological Survey National Map 3D Elevation Program. Approximate 'istorical river and valley profile derived from bathymetric and historical map information. Glacier and terrace profiles estimated from multiple sources listed in figure 1, supplemented by unpublished observations by O'Connor, Waitt, and Cannon. Estimated equilibrated isostatic response to maximum ice and lake loading (Figure 6d) is shown as deflection of the historical river and valley profile. Divide elevations are for selected low areas south of Spokane and Columbia valleys leading to Channeled Scabland tracts and coulees cut into southward sloping Columbia Plateau (as depicted in Figure 6a). Maximum flood-stage evidence from data in Table 3. Key lake levels and stratigraphic section locations and extents from sources cited in text. Glacial Missoula stratigraphic sections are east of the profile. The Mission Valley site is the Landslide Bend section of Levish(1993). 
Calibrated radiocarbon dates ${ }^{2}$ showing the growth and retreat of the Purcell Trench lobe of the Cordilleran Ice Sheet put the advancing ice lobe still north of the Canadian border at $20-22$ ka and its melting edge back north of the border by about $13 \mathrm{ka}$, thus constraining its damming of glacial Lake Missoula to between 22 and 13 ka (Fulton, 1971; Clague, 1980; Waitt, 2016). These dates are consistent with terrestrial cosmogenic nuclide (TCN) dating of five moraine boulders on a prominent near-maximum lateral moraine that give ages between $14.7 \pm 1.2$ and $16.6 \pm 1.5 \mathrm{ka}$, averaging $15.7 \pm 1.3 \mathrm{ka}$ (Breckenridge and Phillips, 2010; age recalculated by Balbas et al., 2017, Table DR2) ${ }^{3}$ A TCN age of $14.3 \pm 1.2 \mathrm{ka}$ (FAR04, Balbas et al., 2017, Table DR2) from a boulder in the area of un mu outwash (Lewis et al., 2002) bordering the southwest margin of Lake Pend Oreille indica $\_s \mathrm{~L}$ e timing of final retreat of the Purcell Trench lobe from the Lake Pend Oreille basin after th ${ }^{1^{1}} \mathrm{~S}_{\iota}$ - ataclysmic release.

Varve counts from lake deposits total 3240-3610 for n luw-elevation exposure in Mission Valley, Montana indicating the duration of the lake (Figure? Figure 8; Levish, 1997, p. 97-98). From optically stimulated luminescence (OSL) dating, Levish _ amates an age range for the lake of 19.2-16.0 ka. OSL dating of transgressive sand beneath lacustrin

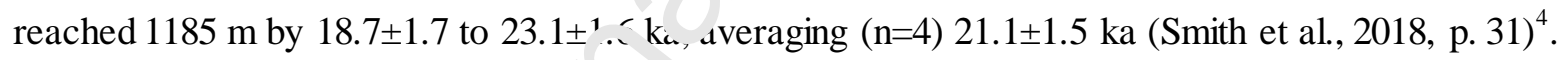
Hanson et al. (2012) report two Os. ages from the Rail Line section (near Missoula) of glacial Lake Missoula sediments of $12.6 \pm 0.6$ and $14.8 \pm 0.7 \mathrm{ka}$, the younger age contradicted by post-lake deposition of the 13.7-13.4 ka Glacic + t _.. tephra (Kuehn et al., 2009) across the lake basin (Konizeski et al., 1968; Levish, 1997, p. 131; Smith, 2004) showing the lake gone by then (Levish, 1997, p. 131). Hofmann and Hendrix (2010, p. 71) infer that glacial Lake Missoula had ended prior to 14.6-14.3 ka from a radiocarbon dated sediment sequence deposited in a proglacial lake dammed by a terminal moraine of the Flathead ice lobe after glacial Lake Missoula had left the basin. These age determinations and inferences

\footnotetext{
${ }^{3}$ Individual TCN ${ }^{10} \mathrm{Be}$ ages from Balbas et al. (2017) are reported as ages \pm external uncertainty, as listed in their Table DR2; site averages are mean \pm standard error as reported in their Figure DR1. Similarly, $\mathrm{TCN}^{36} \mathrm{Cl}$ results from Keszthelyi et al. (2009) are reported as ages \pm external uncertainty ("Error 2" in their Table 2, p. 861) ${ }^{4}$ Individual OSL ages are reported as age \pm standard error.
} 
have some inconsistencies but in general show that glacial Lake Missoula existed for at least 3-4 ky during 20-14 ka.

\section{Columbia Lobe and Glacial Lake Spokane}

The Columbia River lobe of the Cordilleran Ice Sheet descended the Columbia River valley, blocking the Spokane River near its confluence, creating glacial Lake Spokane (Figure 5, Figure 8). The lake attained a stage of at least $671 \mathrm{~m}$ and carved benches between 550 and $610 \mathrm{~m}$ (Kiver and Stradling 1995, p. 138,$139 ; 1991$, p. 238-240), as much as $360 \mathrm{~m}$ above river grade at the nokane-Columbia confluence. Not clear, however, is its timing and role in last-glacial M M is and lake, if extant during releases of glacial Lake Missoula, wou 1 accumulate flood deposits and divert Missoula floodwater coming down the Spokane valley southw act into the Cheney-Palouse flood tract.

This ambiguity affects interpretation of 15-16 flo sa er ssits interbedded with lacustrine sediment in the Latah Creek valley (also known as Hangn. `n $r$,reek) near Spokane (e.g. Waitt, 1984, p. 52-53; Atwater, 1986, p. 37; Kiver et al., 1991, p. _19); Kiver and Stradling, 1995, p. 129; Gaylord et al., 2016, p. 20-21). But this exposure, the top of whit is at about $595 \mathrm{~m}$ (Kiver et al., 1991, p. 241), is 70-90 m higher than similar sequences of de sosic formed in glacial Lake Columbia downstream (Figure 8). This leads us to infer that a higher g'? ${ }^{\prime}$ cial Lake Spokane was indeed a Missoula flood receptacle for the varveseparated flood deposits, as ‘lso nferred by Flint (1936, p. 1858) and Kiver et al. (1991, p. 240). Although it is possible tha ". iey were deposited in a high-level glacial Lake Columbia (Waitt and Thorson, 1983) or a smaller lake formed by local impoundment of the Latah Creek valley mouth by aggradation or flood bar (Flint, 1936, p. 1867; Atwater, 1986, p. 37).

Contributing to the ambiguity is poor resolution of the extent and timing of the last-glacial Columbia ice lobe. Waitt et al. (2016, p. 239), from mapping by Kiver and Stradling (Kiver et al., 1989, p.326; (Kiver and Stradling, 1989, p. 30-31; 1995, p. 12, 112-118), show the last-glacial ice limit north of the Columbia-Spokane confluence and not blocking the Spokane River. In contrast, our recent field 
investigations indicate last-glacial ice did indeed extend beyond the confluence (Figure 1). Last-glacial blockage also may have been by the Enterprise valley sublobe entering the Spokane valley $10 \mathrm{~km}$ upstream of the Columbia confluence (Kiver and Stradling, 1995, p. 108, 120). Direct age information on ice position is limited to $100 \mathrm{~km}$ north near the Canadian border, where a pre-advance radiocarbon age reported by Clague et al. (1980, p. 323) requires that maximum advance post-dated 21.8-20 ka.

Atwater (1986, p. 36, plate 2) also infers last-glacial blockage of the Spokane valley by the Columbia lobe blockage, denoted by four anomalously thin Missoula flood beds in -lacial Lake Columbia deposits downstream. From varve counts tied to a radiocarbon date, he propose : tha Columbia lobe blockage

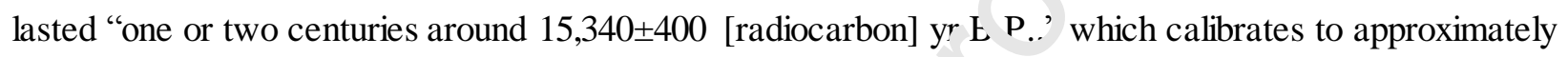
19.6-17.7 ka. Atwater's interpretation, based on varve count , ol only a couple of centuries duration for glacial Lake Spokane possibly conflicts with the duration inpliea by the 15-16 flood beds and interbedded varves exposed at Latah Creek. The vai e counts between Latah Creek flood beds are not fully reported, but range between 10 and 60, wis two intervals containing as many as 125 couplets (Kiver et al., 1991, p. 240), although Waitt (1984. v. 53) posits 55 at most. Very approximately, these counts might indicate a last-glacial Lake $\operatorname{Spo}^{\prime} \ldots$ ne ${ }^{\mathrm{J}}$. ration of $\sim 500 \mathrm{yr}$.

An alternate interpretation off rec for the timing of glacial Lake Spokane is that the lacustrine part of the Latah Creek section war m $n$ an older middle Wisconsin lake and flood episode (e.g. Kiver and Stradling, 1985; Kiver et al., 1991, p. 241). Two radiocarbon dates of detrital organic material within floodbeds low within the sequence give ages of $>40,000$ and $32,450 \pm 830{ }^{14} \mathrm{C} \mathrm{yr} \mathrm{BP}$, possibly consistent with these deposits being older than last-glacial (Gaylord et al., 2016, p. 21). Such ages are largely discounted as too old elsewhere along the flood route because of reworking of the dated materials (e.g. Fryxell, 1962; Benito and O’Connor, 2003). Waitt (1985b) further asserts a middle Wisconsin age is inconsistent with the dated glacial chronology.

Other constraints are offered by geomorphic and stratigraphic relations. Because prominent terraces related to stable levels of downstream glacial Lake Columbia extend far up the Spokane and Columbia 
valleys (e.g. Jones et al., 1961, p 13, 77-78; Atwater, 1986, p. 36; Kiver and Stradling, 1995, p. 138), the retreat of the Columbia lobe from the Spokane confluence and the demise of glacial Lake Spokane must have preceded the end of glacial Lake Columbia. Hanson and Clague (2016, p. 67) also show stratigraphic evidence that the Columbia lobe both advanced and retreated into an extant glacial Lake Columbia within the Columbia valley north of the Spokane River confluence, requiring that glacial Lake Spokane was both preceded and outlived by glacial Lake Columbia. Coarse flood gravel spilled upstream into the Columbia valley near the Spokane River confluence is inferred hy Kiver and Stradling (1995, p. 119) to precede advance of the Columbia lobe as well as glacial Lake $r_{-v i}$ muia, indicating at least one large flood from glacial Lake Missoula (because it came down the spo ane valley) prior to either the Okanogan or Columbia ice lobes blocking the Columbia.

\section{Okanogan Lobe and Glacial Lake Columbia}

The Okanogan lobe descended the Okanogr a (1)kaı ?gan in Canada) River valley, blocking the Columbia River valley near its confluence (Figure -, Figure 6). A sublobe diverted southeast, following the Omak Lake trench (Flint, 1935, p. $17,-. \neg$ ), perhaps separately obstructing the Columbia River valley (Hanson, 1970, p. 129). At eit: 2 r lo ation, advancing ice would quickly dam the narrow Columbia valley to depths greater than 760 is thas creating an ice dam standing at least $530 \mathrm{~m}$ above natural river grade. After first filling the sası west trending Columbia valley, the blocking lobes then spilled across, coalesced and flowed $50 \mathrm{~km}$ south across the Waterville Plateau. At its maximum extent, the Okanogan ice lobe filled $150 \mathrm{~km}$ of Columbia valley between Chelan on the west and Grand Coulee on the east, locally with more than 1000 m of ice (Figure 6d, Figure 8; Kovanen and Slaymaker, 2004). The prominent Withrow moraine marks the broad terminus on the Waterville Plateau (Flint, 1935, p. 177-178; Hanson, 1970, p. 83-88, Kovanen and Slaymaker, 2004). Till of the eastern ice margin rims the west edge of Grand Coulee, and till on Steamboat Rock (Bretz, 1932, p. 35-37), a basalt-floored island stranded by the incision of upper Grand Coulee, shows that the ice sheet once covered at least some of the area of upper Grand Coulee. The western margin of the Okanogan ice lobe sent a short tongue down the 
Columbia valley to near Chelan, where moraines terminate in prominent outwash terraces $230 \mathrm{~m}$ above the natural river grade (Waitt, 1987). This western sublobe was also joined by ice from the more westerly Skagit lobe of the Cordilleran Ice Sheet spilling over passes in the North Cascades and flowing down the Lake Chelan trough (Waitt, 1987).

Blockage of the Columbia valley raised glacial Lake Columbia (Figure 5, Figure 6, Figure 8; Table 1). This lake received and diverted $\sim 100$ Missoula floods coming from the east, leaving a stratigraphic record of interbedded flood sand and lacustrine varves (e.g. Atwater, 1984, 198 5 1987; Steele, 1991; Kiver and Stradling, 1995; Hanson, 2013; Hanson et al., 2015; Hanson and Clagı e, 21 16). The composite Manila Creek section in the Sanpoil valley records $\sim 89$ flood beds (Atw tt. 1 ( $84,1986,1987$ ) - the most complete stratigraphic record of Missoula flooding yet descr oea.

At its end and possibly for much of its existence, gl ci ${ }_{1} 1$ Lake Columbia was at a stable stage of $\sim 470$ m, spilling through rock-bottomed Grand Coul _ ( Itw ater, 1986, 1987). During rapid influx of Missoula flood waters, Lake Columbia briefly swelled to as 'igh as $750 \mathrm{~m}$ near Grand Coulee, marked by ice-rafted erratics at that elevation along the Colum'sa anciSpokane valleys and in the Sanpoil River valley east of Grand Coulee (Figure 8; Table 3; At 'ate, 1986, p. 5-7). Between floods, high short-lived levels of Lake Columbia are traced by patchy sí. `na:nes, beach deposits, and possibly fine-grained valley fill—as high as 715-730 m (Pardee, 191^, p. 1J, Cochran and Warlow, 1980, p. 40 (725 m); Atwater, 1986, p. 6 (715 m); Kahle and Bartolino, 2u 7, p. 13-15 (729 m). This highest lake stage is referred to as "Lake Columbia I" by Waitt and Thorson (1983, p. 57, 67) and Kiver and Stradling (1995, p. 121, 129) and "high level Lake Columbia" by Atwater (1986, p. 5). Lower and slightly more prominent strandlines are preserved between 610 and 700 m east of Grand Coulee (Kiver and Stradling, 1995, p. 15, 61, 138), near and within the Sanpoil River valley (Flint, 1935, p. 189; 1936, p. 1857; Cochran and Warlow, 1980, p. 43), and in the Columbia valley upstream of the Spokane River confluence (650-670 m; Flint, 1936, p. 1857). Long-stable lake levels are shown by strongly formed benches between 475 and $535 \mathrm{~m}$ that are nearly continuous along the Columbia valley upstream of the Okanogan River confluence. Chiefly 
composed of bedded silt and sand but commonly capped by fluvial gravel, these benches in part correspond to the "Nespelem silt" of Pardee (1918, plate 1, p. 15, 28-29). They hold the key stratigraphic sections of Manila Creek (Atwater, 1984, 1986) and Hawk Creek (Hanson, 2013; Hanson and Clague, 2016). Kiver and Stradling (1995, p. 17, 67, 124, 140) distinguish two levels among these prominent surfaces, a "Lake Columbia II" stage at 510-535 m that stands distinctly higher-our observations indicate about $30 \mathrm{~m}$ near the Spokane-Columbia confluence - than the "Lake Columbia III" terraces at 475-490 m (Figure 8), which they infer grade to the modern 470-m Grand Coulee threshold.

What controlled the various stages of glacial Lake Columbia and $\mathrm{u}$ hy $\mathrm{d}$ it not repeatedly empty like glacial Lake Missoula? Unlike glacial Lake Missoula, deeply co’f $f_{L} \cdot e d$ vithin Rocky Mountain valleys sloping down toward the ice dam, glacial Lake Columbia wa s bo dered on the south by the uplifted and wrinkled but generally south-sloping basalt of the Columhia Plattau. Along this southern lake border, low spots afforded overflow routes to the south at lake s. ges well below those that could destabilize the ice dam, especially when ice was thick over the Con nbia valley and advanced onto the Waterville Plateau (Figure 6a, Figure 8, Atwater, 1986, p. 4). Thu distribution and elevations of these low spots, in conjunction with the advancing Okanr $g^{\prime n} .^{-1}$ e, dictated lake level. Key elevations from west to east are: (1) $653 \mathrm{~m}$ for the divide near Mans. "eld ıeading to southward draining Moses Coulee; (2) the 470-m threshold bottom of upper Granc Cr ulee, the lowest by far and the outlet that clearly controlled lake elevation at the end of the 'רs, oracial (Figure 6Error! Refe rence source not found.f; Flint and Irwin, 1939; Waitt and Thorson, 1983; Atwater, 1986, 1987); (3) the 706 m threshold of the Hawk Creek divide separating the Columbia valley and the Telford-Crab-Creek scabland tract; and (4) the $703 \mathrm{~m}$ threshold dividing the Spokane River valley from the Cheney-Palouse scabland tract. These outlet elevations are determined from 3-6 m contour-interval topographic maps and have uncertainties of similar order. Moreover, these elevations have been almost certainly affected by isostatic adjustments, as discussed in the next section. Despite these uncertainties, the evidence for lake levels $\sim 250 \mathrm{~m}$ higher than the 470-m modern Grand Coulee outlet requires that Grand Coulee had not yet fully incised or that it was 
temporarily filled with ice, as discussed in the "Grand Coulee" section. Similarly, lake levels above the $653 \mathrm{~m}$ level of the entrance to Moses Coulee also require ice-blockage or later erosion of the head of that coulee.

Timing of the Okanogan lobe's interaction with the Columbia River is known by the glacial chronology as well as the stratigraphy and chronology of glacial Lake Columbia deposits. A radiocarbon age from deposits preceding ice advance shows that the Okanogan ice margin was at least $250 \mathrm{~km}$ north of the Columbia confluence at 23.6-22.5 ka (Clague et al., 1980, p. 323- ${ }^{225)}$. The youngest of five ages reported by Hibbert (1985, p. 98) from carbon-rich sediment and peat velor Okanogan lobe till exposed in the Columbia valley calibrate to $36-24 \mathrm{ka}$. Four ${ }^{10} \mathrm{Be} \mathrm{TCN}$ ag $\mathrm{s}$ of $\mathrm{m}$ rraine boulders on the Withrow moraine show that the Okanogan lobe pulled back from its $n$ axil um extent on the Waterville Plateau after $15.4 \pm 1.4 \mathrm{ka}$ (site mean \pm standard error), perhaps hof ore the down-Columbia sublobe (which was bolstered by the Skagit ice lobe coming down the C: $:$ lan urough) pulled back from its maximum extent near Chelan by $14.5 \pm 1.2$ ka (Balbas et al., 201\%, Within uncertainties, these ages mostly concur with more variable ${ }^{36} \mathrm{Cl}$ TCN ages of $16.3 \pm 1.0 \mathrm{ka},: 3.2 \pm 0.9 \mathrm{ka}$, and $12.2 \pm 1.1 \mathrm{ka}$ obtained by M. Zreda and V.R. Baker on erratics inferred left by ¿ka."gan lobe near its southeastern limit on top of Steamboat

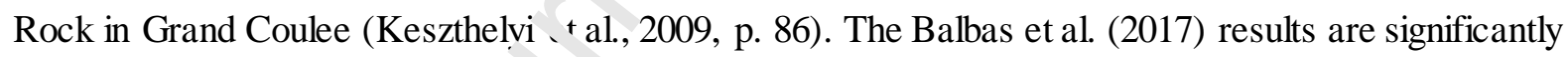
younger than previously reporte. ${ }^{36,}, 1 \mathrm{TCN}$ ages of $29.4 \pm 0.8$ to $22.3 \pm 0.8 \mathrm{ka}$ for the Withrow moraine (recalculated by them fro.' ru uts reported by Swanson and Caffee (2001)). The Okanogan lobe had retreated 15-20 km north trom the Columbia River confluence by the time 13.7-13.4 ka Glacier Peak tephra fall (Kuehn et al., 2009), judging from its preservation on the floor of the lower Okanogan valley (Porter, 1978, p. 39).

Age estimates from glacial Lake Columbia, impounded by the ice lobe, derive from radiocarbon dates, the presence of the Set S tephra, and varve counts. Two radiocarbon dates from detrital plant material within varved lacustrine sediment give ages of 14,490 $\pm 290{ }^{14} \mathrm{C} \mathrm{yr}$ BP (Atwater, 1986, p. 29; Manila Creek section) and 13,400 $\pm 100{ }^{14} \mathrm{C}$ yr BP (Hanson and Clague, 2016, p. 74; Hawk Creek section), 
showing the lake persisted until at least the 16.4-15.8 ka calibrated age of the younger date. Additional lake duration of several centuries beyond this younger age is implied by 37 flood beds inferred above the 16.4-15.8 ka sample at Hawk Creek (Hanson and Clague, 2016, p. 74). From varve counts at the Manila Creek section in the Sanpoil valley, Atwater (1986, p. 11) estimates a total lake duration of 2,000-3,000 yr. If we accept the 18.35-16.83 ka Manila Creek calibrated radiocarbon age and account for its position with respect Atwater's (1986) varve counts and their uncertainties, the Manila Creek section shows lake onset began by 19.1-17.5 ka and the last Manila Creek varve was laid dnwn sometime within 17.1-14.6 ka. As Atwater (1986, p. 29) notes, these ages for lake onset and demi _ _ ay be too old if the detrital wood was older than the enclosing deposits. The timing of the last var $:$ at Manila Creek includes an estimated 200-400 varves above the uppermost flood bed (A $\cdots$ atc $: 1987$, p. 185-187). From this Atwater infers that glacial Lake Columbia outlasted blockag > o, the Clark Fork by the Purcell trench lobe and impoundment of glacial Lake Missoula by $2-4$ c rn rie ; suspecting, however, that this is an underestimate because of poor exposure (Atw ter 2020, written communication).

Hanson's (2013, p. 90, 116, 206) discover, of the Mount St. Helens Set S tephra in the Manila Creek

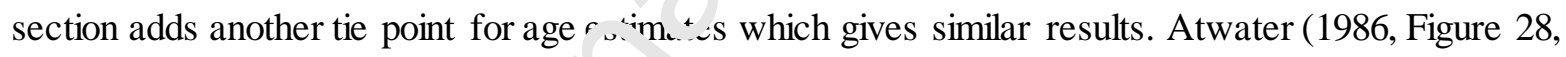
Plate 3) counted 70-100 varves be veen the position of the Set S found by Hanson, 15-17 flood beds from the top, and the highest flo 1 red at the Manila Creek section, indicating about a century of Missoula floods in this sc . +iun after the $\sim 16$ ka tephra fall. Varve counts below the tephra total 16552525 (Atwater, 1986, Figure 28, Plate 3), indicating glacial Lake Columbia formed by 18.5-17.7 ka, as measured from the $\sim 16 \mathrm{ka}$ age of the Set $\mathrm{S}$, which also has poorly resolved uncertainty of several hundred years (Clynne et al., 2008).

An assessment of the Manila Creek section independent and discordant from the varve counts is Hanson's (2013) analysis of the paleomagnetic secular variation within the uppermost $\sim 46$ flood beds and intervening lacustrine deposits. Correlating the measured secular variation to an established reference curve, Hanson (2013, p. 114) estimates that the deposits formed over a period of 2600 years between 14.2 
and $11.6{ }^{14} \mathrm{C}$ ka BP, equating to $17.3-13.4 \mathrm{ka}$. Extrapolating based on Atwater's 1986 description of $\sim 40$ additional stratigraphically lower flood beds and the 55 yr recurrence interval estimated from the secular variation within the upper part of the section, Hanson (p. 115) suggests that the base of the lacustrine deposit is $\sim 2200$ years older, about $19.5 \mathrm{ka}$, a result about 1 ky older than the radiocarbon based chronologies. Moreover, in contrast with the 2600-yr age span and the average 55-yr interflood interval inferred from secular variation, the varves interbedded with the upper 46 flood beds at Manila Creek likely total 600-1000 and no individual interflood interval has more thar 27-37 varves (Atwater, 1986, his figs. $15-17$ and plate 3 ).

Taken together, the chronologic information indicates the Ok`n rar lobe blocked the Columbia River for 2-5 ky after $19.5 \mathrm{ka}$ and before $13.5 \mathrm{ka}$, and during the $\sim 6 \mathrm{k}$. Mount St. Helens tephra fall. The radiocarbon- and tephra-based chronologies from the Mrnild Creck section give a tighter approximate range; 18.5 ka to $\sim 15.5 \mathrm{ka}$ with about $1 \mathrm{ky}$ uncerta: ty lur both beginning and ending.

\section{Isostatic Deformation}

For all three glacial lakes, their elevatıo is. volumes, and outlets were affected by isostatic depression and rebound as the masses of ice ar $\mathrm{d} w$ ter came and went. Warping also likely affected flood routes and gradients. The complicated sut nerє unce and emergence patterns and their hydrologic consequences in the Puget Sound area de no stra e these effects (Thorson, 1989). In conjunction with the Okanogan ice lobe, isostatic adjustments - e most evident in the elevation of lacustrine silt deposited in glacial Lake Columbia where its outlet arm extended south through upper Grand Coulee to the $\sim 470 \mathrm{~m}$ lip of Dry Falls. Here the silt terrace rises north, toward the main masses of ice and water, from $480 \mathrm{~m}$ to $500 \mathrm{~m}$ elevation over 40 km (Flint, 1935, p. 189; Atwater, 1987, p. 188). This northward tilt of $0.5 \mathrm{~m} / \mathrm{km}$ approximates the $0.6 \mathrm{~m} / \mathrm{km}$ of net northward tilt in Puget Sound as it rebounded from the mass of Puget lobe (Dethier et al., 1995, p. 1299). 
We have the estimated regional isostatic response to ice and lake loading by finite element modeling of the maximum ice and lake extents shown in Figure 6d and Figure 8. These calculations assume a fully equilibrated flexural response governed by the thickness and rigidity of the crustal structure estimated by Buehler and Shearer (2010) from seismic interferometry. Results are shown in Figure 8 in relation to the historical river and valley profile along the flood route between Wenatchee and the Clark Fork River valley. Importantly, the actual magnitude of isostatic elevation change for any specific feature depends on when the feature formed in relation to loading and the dynamic crustal $\mathrm{r}^{\circ}$ sponse, which is mostly unknown. The portrayed deflection indicates maximum plausible elevi w aüjustments for last glacial features along the river and valley profile. For example, where the Oka logan lobe was thick and broad over the Columbia valley near the Okanogan River confluence, rv estimate nearly $\sim 90 \mathrm{~m}$ of equilibrated depression at maximum loading. The magnitude diminishes to se south and east in a manner approximating the observed northward rise of lacustrin silt in upper Grand Coulee. The results also indicate $\sim 40 \mathrm{~m}$ of differential post-glacial upli $: \mathrm{a}^{2}$ ng the trace of the southern divide and outlets of glacial Lake Columbia. This variation bring. the last-glacial maximum elevations of the less-uplifted divides entering the Cheney-Palouse and T $\mathrm{st}$, $\mathrm{d}$ d-Crab-Creek scabland tracts (now at 703 and $706 \mathrm{~m}$ ) to 20-30 m above the 715-m-high shc ielı evidence in the Sanpoil valley described by Atwater (1986, p. 6-7), which our calculations show c. pressed to about $680 \mathrm{~m}$ elevation at the time of maximum ice and lake extent.

Isostatic loading to the west as the Okanogan lobe advanced may have facilitated progressively greater flood flows into Moses Coulee and Grand Coulee as the entrances to those tracts were weighted down (but prior to being blocked) by the advancing ice and resulting lake. Differential uplift complicates also correlation of terraces related to glacial lakes Columbia and Spokane (Kiver and Stradling, 1995, p. 141142). Broadscale tilting also affects flow-path gradients, adding uncertainty to the flow modeling results based on modern topography. Isostatic deformation beneath glacial Lake Missoula may also require adjustment of lake volume estimates based on modern topography, much like it does for pluvial Lake 
Bonneville (e.g. Abril Hernandez et al., 2018, p. 2-3). For many reasons, better understanding of the rates and patterns of regional isostatic deformation in consequence of the various ice lobes and resulting glacial lakes would help overall understanding of the lakes and floods.

\section{Missoula Flood Routes}

All floods from outrushing glacial Lake Missoula exited the lake basin through the Clark Fork valley in western Montana and entered the eastern Pacific Ocean by way of the Columbia River through the Columbia River Gorge (Figure 1Error! Reference source not found.) Ru hetween leaving the lake and entering Wallula Gap, the plexus of flood routes depended on conr'iu's at the breaching ice dam, the position of the Okanogan ice lobe, the status of glacial lakes Colu nbia and Spokane, progressive erosion of the scabland tracts, and release size. After entering the Pac. ${ }_{\llcorner}=$Ocean, flood waters may have taken different submarine routes depending on ocean conditic $n$,.

\section{Clark Fork and Flathead River Valleys}

At maximum ice and lake extent, the ${ }^{1} \varkappa$ knt-long Clark Fork valley between Lake Pend Oreille and the confluence of the Flathead River vas ccupied by ice and the deep and narrow downstream arm of glacial Lake Missoula, here conf: 'ea hy the Cabinet and Bitterroot Mountains of western Montana and northern Idaho. The narrow's s ec con is "Eddy Narrows" (Figure 1Error! Refe rence source not found.; Pardee, 1942, p. 1574), whe : at its maximum 1295 m elevation (Table 3), glacial Lake Missoula spanned only $2.25 \mathrm{~km}$ across. When the ice dam failed, however, the Clark Fork valley, as well as the lower Flathead River valley, became raging flood conduits for water funneling out of the voluminous basins upstream in the upper Clark Fork and Flathead River drainages, constrained by bottlenecks like Eddy Narrows (Pardee, 1942, p. 1594-1597). The outrushing floodwater left immense dune-covered boulder gravel bars in the valley bottom and high eddy bars in tributary mouths (Figure 7c) and intensely eroded the Proterozoic metasedimentary rocks forming the valley walls (Pardee, 1942; Smith, 2006). Inset against and locally capping the coarse flood deposits are silt, clay, and lesser amounts of sand and gravel 
in sequences up to $25 \mathrm{~m}$ thick (Figure $7 \mathrm{~b}$ ). These beds are inferred to be lacustrine sediment deposited in reformed glacial Lake Missoula (Pardee, 1942; Smith, 2006), and have been studied as records of the number and timing of lake drainages (Alt and Chambers, 1970, Chambers, 1971; 1984; Curry et al., 1977; Waitt, 1980, 1985a; Fritz and Smith, 1993; Levish, 1997; Shaw et al., 1999, 2000; Atwater et al., 2000; Hanson et al., 2012; Hanson, 2013; Smith and Hanson, 2014).

Table 3. Evidence of maximum Missoula flood stages, selected from multiple sources and new observations (as noted). All sites were reevaluated using modern imagery and topographic maps, resulting in many levation and location adjustments from original sources. Elevations of positive evidence offloods, such as eroded rock, crosse :.."iac , and ice-rafted erratics were attributed to the highest elevation contour below the feature, except where nearby'.. ‘n....urks or checked elevations provided more precise information. Similarly, elevations of features inferred not flooder sucin s divides not crossed, were attributed to the lowest elevation contour above the feature. Where original evidence, r. artic 'arly erratics, could not be evaluated remotely, elevation and location information are noted "as reported."

\section{Spokane-Rathdrum Valleys}

Floods exited the breached ice dam nea the souh shore of Lake Pend Oreille. Some water diverted northwest into the Pend Oreille River valer a ad then circled back south to the Spokane River valley northeast of Spokane by way of the L. tle Spokane River valley (Figure 5; Kiver and Stradling, 1982; Waitt, 1984; O’Connor and Baker, '992; Waitt et al., 2016). Most water, however, coursed southwest through Rathdrum and Spol ane-valleys (Bretz et al., 1956; Baker, 1973). This 75-km long trench narrows from about $12 \mathrm{~km}$ wide at its head to $5 \mathrm{~km}$ wide just east of Spokane. In most places the valley bottom is filled with 200-250 m of Pleistocene glaciofluvial and flood deposits documented by well logs and seismic data (Bolke and Washington, 1980; Gerstel and Palmer, 1994; Kahle and Bartolino, 2007, p. 1718 , plate 2).

Floods speeding through this route eroded midvalley knobs and bedrock valley slopes, deposited massive foreset-bedded gravel bars, some mantled with giant current dunes, and left valley-blocking eddy bars in tributary mouths (Flint, 1936; Richmond et al., 1965; Weis and Richmond, 1965; Weis, 1968; 
Baker, 1973; O’Connor and Baker, 1992; Breckenridge and Othberg, 1998a, b; Lewis et al., 2002; Waitt et al., 2016). High eddy bars, divide crossings, scabland, and ice-rafted erratics define maximum-flood stages declining from $810-820 \mathrm{~m}$ near the southern tip of Lake Pend Oreille to $~ 780 \mathrm{~m}$ near Spokane and downstream (Table 3; Figure 8; Baker, 1973, p.17; O’Connor and Baker, 1992, p. 274). These stages are as much as $170 \mathrm{~m}$ above the present valley floor. Side-valley lakes in tributary valleys now blocked by eddy bars, like 64-m-deep Coeur d'Alene Lake (Woods and Behrenbrock, 1994), suggest a pre-flood main-valley bottom $60-70 \mathrm{~m}$ lower than present and flood depths as great as $\sim 250 \mathrm{~m}$.

Floods entering the Spokane-Rathdrum valley at times encounterec glac al Lake Columbia or possibly glacial Lake Spokane whenever lake stages exceeded $\sim 600 \mathrm{~m}$ ele vi tion At its maximum stage of 715 $730 \mathrm{~m}$, glacial Lake Columbia would have reached the termi al s. oraine now impounding the southern arm of Lake Pend Oreille (Figure 6Error! Reference smise not found.d; Figure 8). And the $750 \mathrm{~m}$ flood swollen stage of glacial Lake Columbia (Atwa er, 1yð6, p. 5-6) would impede and elevate Missoula flood stages through the valley (O’Connor and ` ‘ker, 1992, p. 275). At glacial Lake Columbia’s minimum stable level, draining over the prest. + Grand Coulee threshold at $470 \mathrm{~m}$, the valley would be lake-free (Figure 6Error! Reference $\curvearrowright$ ur not found.f). It is also likely that glacial Lake Spokane at its maximum level $\sim 670 \mathrm{~m}$ (Kiver anc Stracling, 1995, p. 137-139) backflooded the valley near Spokane and would be engorged by Miss 'la floods down the Rathdrum valley. One or both of the glacial lakes seem recorded in the Rat. ${ }^{1}{ }^{r} u_{\ldots .}$ valley by fine-grained layers in the valley fill, ranging between 504-729 $\mathrm{m}$ in Rathdrum Prairie and a prominent layer, 49-81 $\mathrm{m}$ thick and topping at elevations of 505-524 $\mathrm{m}$ in the western Spokane valley north of the main floodway (Kahle and Bartolino, 2007, p. 13-15).

This reach has had a long history of Quaternary investigations. Some of what are now interpreted as Missoula flood deposits were originally thought glacial, leading to inferred last-glacial ice margins south and west of Spokane (Bretz, 1928b; Flint, 1936, 1937), much beyond current mapping of the last-glacial Cordilleran ice sheet in northeast Washington and Idaho (Waitt et al., 2016). Balbas et al. (2017, Table DR2) report a ${ }^{10} \mathrm{Be}$ exposure ages ranging from $14.3 \pm 1.2$ to $17.2 \pm 1.4$ for three boulders deposited on one 
of the broad expansion bars at the head of the Rathdrum valley. The southwest edge of Lake Pend Oreille is bordered by till, dated by the $14 \pm 1.2{ }^{10} \mathrm{Be}$ exposure age on a protruding boulder (Balbas et al., 2017, Table DR2, FAR04), showing by its position that the Purcell Trench lobe blocked the Clark Fork valley after the last substantial lake outflow (Breckenridge et al., 1989, p. 19; Lewis et al., 2002; Smyers and Breckenridge, 2003, p. 13). Final outwash and minor flooding (if any) flowed northwest through the small Hoodoo Channel to the Pend Oreille River valley.

The Latah Creek section near Spokane has been the major stratigrapl- focus in this reach (Rigby, 1982; Kiver and Stradling, 1982, 1985; Waitt, 1984, 1985b; Kiver et a', 1‘ 71 ; Meyer, 1999; Gaylord et al., 2016, p. 18-26), although Waitt (1984) describes additional re tion , in the area. At Latah Creek, 1516 floods left turbidite-like beds in glacial Lake Spokane or oss. 'ly a high level of glacial Lake Columbia, overlain by another 12 flood beds subsequen ${ }^{+t}$ lake withdrawal and local incision (Waitt, 1984; Gaylord et al., 2016, p. 18-26). The lacustrinc depusits in the valley reach $\sim 600 \mathrm{~m}$ elevation and may correlate with the fine-grained layers in the alley fill described by Kahle and Bartolino, 2007, p. 1315). As noted above, the age of this section is ncertain. Waitt $(1984,1985 b)$ asserts that it is entirely last glacial, yet Kiver et al. (1991, p. 241) _. gg _ the lower, lacustrine, part may be middle Wisconsin, in part based on several radiocarbon dates rom nearby flood sediment by giving ages of 30-40 ka (p. 238).

\section{Cheney-Palouse Trac.}

Floods exiting the Spc.-n te and Rathdrum valleys entered the deep but narrow Spokane River valley on its $120-\mathrm{km}$-way west to meeting the Columbia River valley coming in from the north. The immense flood volumes overwhelmed the tortuous drainage, at times already partly filled by glacial lakes Spokane and Columbia. Spilling west and south, the floods overtopped the northern edge of the basalt plateau and its cover of old alluvium and loess. The diverted water carved the Cheney-Palouse scabland tract, a plexus of basalt-floored channels extending $150 \mathrm{~km}$ southwest from the Spokane area, mainly toward the Snake River and Pasco basin. It is the longest and easternmost of the scabland tracts (Figure 5). Ragged, sharpedged channels starkly contrast with the rolling loess hills of the Palouse, commonly left as streamlined 
'loess islands' between floodways (Figure 9; Washington Department of Natural Resources, Division of Geology and Earth Resources, 2016). This contrast prompted Bretz’s (1923a, p. 573) first paper advocating flows of "great vigor over large tracts."

Figure 9. GoogleEarth image of a part of the Cheney-Palouse tract showing plexus of scabland eroded into the basalt of the Columbia River Basalt Group separated by streamlined "islands” of uneroded loess uplands. Area of figure shown in Figure 5.

Maximum flood levels reached 770-780 m spilling out of the Spokane River valley into the CheneyPalouse tract (Table 3; Figure 8). The now-eroded cols of those divides $a^{2}=703 \mathrm{~m}$ for the large eastern tract chiefly following Rock Creek and the Palouse River, ultimately 1 adin s to the Pasco basin, and 721 $\mathrm{m}$ for the smaller western tract which shunted some flow into the $C \cdot \neg \mathrm{b}$ Jreek drainage and Quincy basin (Figure 5, Figure 6Error! Reference source not found.a). 7 hes, divides stand 240-255 $\mathrm{m}$ above the present Spokane River valley bottom. Flow in the eastem scabland tract sloped steeply southwest, guided by the south dipping surface of the Columbia River : asaı Group. At the divide between the former Palouse River course of Washtucna Coulee ana ' e Snake River canyon, maximum stages were about 460 m, descending to about $410 \mathrm{~m}$ at the conflıen - of the Snake and Palouse Rivers (Bretz, 1928a, p. 646). Floods poured into the Snake River $\mathrm{C}_{\boldsymbol{1 1}_{2}}{ }^{\prime} \mathrm{O}_{\mathbf{1}}$, all water eventually heading west to Pasco basin but some at first backflooding $250 \mathrm{~km}$ up the $S_{1}$. ke River leaving pebbly silt and ice-rafted erratics as high as $395 \mathrm{~m}$ near Lewiston and slackwater dt ${ }_{1}$ ○` its far up the Snake River in Hells Canyon (Bretz, 1929a, p. 405-427; Schmidt et al., 2009; Kurı Thiuerg, Idaho Geological Survey, written commun., 2017).

Bretz's (1923a) first report on the Cheney-Palouse tract identified (and named) the eroded "scabland" (p. 577-579). He described channels excavated into $\sim 60 \mathrm{~m}$ of loess (p. 588) and then as deep as $60 \mathrm{~m}$ into the basalt, anastomosing between "isolated linear groups of Palouse Hills, their marginal slopes steepened notably" (p. 588). Within the channels are "great bars and terraces" (p. 584), chiefly in the lee of basalt outcrops. Bretz returned (1928a, p. 646-664), mainly describing the bars but also the flood-caused diversion of the Palouse River from its former Washtucna Coulee path west southward to the Snake River (Figure 5). The Cheney-Palouse tract also attracted flood doubters; especially Flint (1938) who proposed 
that the bars were instead terraces recording regional aggradation. Allison (1941) soon after noted the implausibility of severalaspects of Flint's fill hypothesis, instead suggesting many of the features in the Cheney-Palouse were caused by ice jams downstream that impounded a temporary lake. Patton and Baker (1978a) later mapped the Cheney-Palouse tract, describing the morphology of scabland flood forms and relating them to erosional and depositional processes.

The scabland and giant floods bars of the main Cheney-Palouse scabland tract are spectacular, but the backflooded valleys entering from the east best preserve stratigraphic re r rds. These valleys were systematically described by Bretz in 1929(a) where he documents "pe bly ilt" (e.g. p. 402), commonly containing erratic clasts, inferred ice-rafted, as well as current stru 'ure, locally showing up valley transport. The maximum elevations of these backflood depos its a e similar within individual drainages but descends among the drainages, north to south, following the overall scabland gradient (Table 3). These deposits are most studied along the Snake vain $\mathrm{v}$ ustream of the Palouse River confluence, where energetic water from the Cheney-Palouse tract $\Lambda^{\prime} i$ bedded silt and sand up the Snake River and its tributary valleys. Exposures in the Tucannon . alley, which joins the Snake valley $5 \mathrm{~km}$ upstream of the Palouse confluence (Figure 5), record anu. 25 floods (Smith, 1993, p. 95) that passed over the PalouseSnake divide and up the Snake valı., including seven that post-dated the $\sim 16$ ka Mount St. Helens tephra (p. 98). The number accords wh. th 221 fine-grained Missoula flood beds $130 \mathrm{~km}$ farther up the Snake valley overlying bouldery .ra.. I left by the 18.3-18 ka Bonneville flood coming down the Snake River (Figure 4e; Waitt, 1985a, p. 1277). Foley (1976, p. 33-34) reports that slackwater deposits up the Snake River near the Idaho border overlie alluvium containing charcoal dated 16.2-15 ka.

The Cheney-Palouse tract also contains evidence of earlier flood episodes (Patton and Baker, 1978b; Baker et al., 1991; Bjornstad et al., 2001). Most compelling are gravel bars capped by thick petrocalcic horizons appended to the downstream tails of loess islands, such as the Marengo locality (Baker et al., 2016, p. 51) where foreset-bedded flood gravel is overlain by paleomagnetically reversed loess and a 
petrocalcic horizon giving a $\mathrm{Th} / \mathrm{U}$ radiometric age of $800 \mathrm{ka}$ (Bjornstad et al., 2001). The locations of these deposits show that at least some of the channels of the Cheney-Palouse tract had incised earlier.

\section{Telford-Crab-Creek Tract}

Some floodwater entering Crab Creek and Quincy basin came by way of the Telford-Crab-Creek scabland tract, $60 \mathrm{~km}$ east of the Cheney-Palouse (Figure 5). This plexus of shallow basalt-floored channels formed by flood-flow overtopping in several places along a $25-\mathrm{km}$-wide swath south of the Spokane-Columbia River confluence. The lowest divide saddle is at $706 \mathrm{~m},-380 \mathrm{~m}$ above the Columbia River valley bottom (Figure 6a, Figure 8). Most flow followed the $r_{\text {.. }}{ }_{\text {fluu }}$ southwestward drainages of Crab Creek, Coal Creek, Duck Creek, Lake Creek, Marlin Hollo.'Canniwai Creek, and Wilson Creek; carving ever-deepening coulees into the Columbia River Basa ${ }^{1+} \boldsymbol{C}_{\text {,roup }}$ before spreading into the broad 2000- $\mathrm{km}^{2}$ Quincy basin. Maximum flood stages desce $\mathrm{id}$ / $\mathrm{d}$ steeply from 760-770 $\mathrm{m}$ where they first spilled into the tract from the Columbia Valley to $: 10-120 \mathrm{~m}$ in Quincy basin (Table 3).

Despite the pronounced scabland tract le.+ by flood water exiting the Columbia valley, preliminary two-dimensional flow modeling (discussec ${ }^{\prime}$ bf low) shows that this tract only conveys substantial water if boosted by glacial Lake Columbia : tan 'ing at a high level, requiring blockage of the Columbia River by the Okanogan lobe and that up rer $\mathrm{G}$ and Coulee is also blocked (Baker et al., 2016, p. 15-17; Denlinger et al., in press). We kno o no ,eochronology or stratigraphic studies for this little-studied tract. And no evidence of older flooding ${ }^{h}+$ s yet been found.

\section{Grand Coulee}

Grand Coulee is an 80-km-long trench extending southwestward from the Columbia River valley to Quincy basin (Figure 5, Figure 10). It is $1.5-8 \mathrm{~km}$ wide and cuts as much as $340 \mathrm{~m}$ into adjacent basalt uplands and underlying granitic rocks. The coulee and its genesis were beautifully described by Bretz (1932), Bretz et al. (1956, p. 967-974) and Bretz (1969, p. 522-524). As inferred by $19^{\text {th }}$-century observers, Grand Coulee held a diverted Columbia River when blocked from its big bend route around the 
northern margin of the Columbia River Basalt Group by ice of the Okanogan lobe (Figure 6Error! Reference source not found.d; Parker, 1844, p. 307; Symons, 1882, p. 109, 119-120; Russell, 1893; Dawson, 1898). Bretz (1932) clarified the role of huge floods in carving the coulee (though Symons [1882, p. 120] postulated formation by “a flood of water or ice”). Advancing Meinzer's (1918) assessment, Bretz (1932) attributed erosion of the coulee to headward erosion by giant cataract complexes; the lower Grand Coulee (p. 61) by a set of cataracts head-cutting $30 \mathrm{~km}$ north along the southwest trending Coulee monocline, stalled and preserved as the spectacular 120-m-high Dry Falls complex. Above Dry Falls, upper Grand Coulee (p. 47-61) formed by In $^{\text {th }} \mathrm{t}_{i}$ ' cataract system retreating nearly $40 \mathrm{~km}$ north from where the Coulee monocline bends north ast. The upper cataract completed its erosional work all the way to the Columbia River valley, con ${ }^{\cdots} \eta_{\mathrm{ll}}$. itself as it opened a 2.7-km-wide, 250-m-deep entrance to upper Grand Coulee floored $175 \mathrm{~m}$ :bu e the Columbia.

Figure 10. View north of upper Grand Coulee. Steamboat $\Gamma$. ck mu-coulee in the obscure distance. Banks Lake, hemmed in by low dams built at both ends of the coulee now floods,$\circ$ ir egular coulee bottom to $\sim 479 \mathrm{~m}, \sim 10 \mathrm{~m}$ above the historical $470-\mathrm{m}$ threshold at the south end of the lake. Glacial Lake `rlumbia sediments flanking Banks Lake include the Paynes Gulch section described by Atwater (1987, p. 192-195), as high is « ¿ m, and probably graded (but isostatically uplifted) to the 470-m outlet elevation (Atwater, 1987, p. 188). Photograpl by '`uce Bjornstad.

Grand Coulee and its flanking n. lands are marked by flood and glacial features, and its bottom hosts flood bars coated by lacustr ne c ?posits left late in glacial Lake Columbia's occupancy (Figure 10). Most spectacular are the scabland oulees and cataracts. The lower coulee, from the Dry Falls cataract complex to Quincy basin, is a wild maze of dry canyons, vertical plunges, and deep holes carved into the basalt (Bretz, 1932, p. 8-32). The upper coulee is chiefly a vertical walled-trench, $2 \mathrm{~km}$ across and $250 \mathrm{~m}$ deep, but it widens to $8 \mathrm{~km}$ across where it is joined by sets of cataract-headed (and beheaded) canyons from flood flow on the flanking uplands spilling into upper Grand Coulee. This widening is possibly where retreat of the upper cataract slowed or stalled upon the rising granitic rocks outcropping under the Columbia River Basalt Group. Here also the mid-coulee prominence of Steamboat Rock preserves an island of original flood- and ice-scoured basalt upland. In the coulee bottom bouldery flood bars lie in 
protected side-canyon mouths, in the lee of Steamboat Rock and other knobs and mesas (Bretz, 1928a, p. 670), mounded in wider coulee segments, and in the broad pre-flood depression of Hartline basin north of Dry Falls between the upper and lower coulee segments (Bretz, 1932, p. 23-26, p. 44-45, 52-53, 68, 7273).

Upper Grand Coulee closely traces the eastern limit of the maximum last-glacial extent of the Okanogan lobe on the Waterville Plateau (Figure 5, Figure 7d; Bretz, 1932, p. 34-38, plate 1; Waters, 1933, p. 785-787; Flint, 1935; Hanson, 1970, p. 128-129; Waitt and Th`“'son, 1983). Steamboat Rock, the remnant island of upland in the upper Coulee, is partly mantled wi h gli cial till (Bretz, 1932, p. 3537), as is the upland west of the upper coulee. Bretz (1932, p. 36 '?) a d Flint (1935, p. 179) describe features possibly glacial on the coulee floor, leading Bretz tr. inte that the upper cataract retreat was complete and the coulee was fully entrenched before fin ${ }^{1}$ occupation by the Okanogan lobe. This

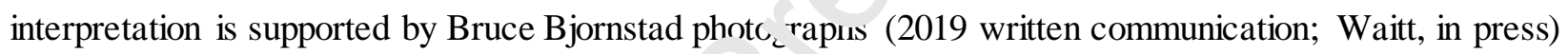
of glacial striae etched into granite along the sh $*$ of Banks Lake in the coulee floor $2 \mathrm{~km}$ northeast of Steamboat Rock.

Geochronology for last-glacial Gr: nd Coulee flooding is chiefly by TCN dating of granitic surfaces exposed by erosion of the overlyi. ? ᄂ.salt. Keszthelyi et al. (2009, p. 861) report a ${ }^{36} \mathrm{Cl}$ exposure age of 17.2 \pm 2.7 ka for an exhume' ins 'lberg near the head of Grand Coulee. Balbas et al. (2017; Table DR2) report exposure ages of $14.5 .-1.2,15.8 \pm 1.3$ and $16.0 \pm 1.3$ from ${ }^{10} \mathrm{Be}$ analyses of exhumed granitic rocks within the Northrup Canyon cataract complex, indicating the timing of the most recent floods across the upland scabland east of the coulee and erosion of the capping basalt within the abandoned cataracts. Two OSL ages, both greater than 36 ka and seemingly erroneously old, are reported by Keszthelyi et al. (2009, p. 861) for lacustrine deposits near Steamboat Rock. No pre-last-glacial flood deposits have been found in Grand Coulee.

The present Grand Coulee outlet threshold at the south end of Banks Lake near the brink of Dry Falls held glacial Lake Columbia at $470 \mathrm{~m}$ during the late phase of Missoula flooding (Table 1; Figure 
6Error! Reference source not found.f; Figure 8). Varved lacustrine silt and clay covering the floor of upper Grand Coulee, the outlet arm of the lake, and in the adjacent Columbia valley up to elevations of 504 m (Figure 10; Bretz, 1932, p. 76, 78; Atwater, 1987) suggest a persistent lake graded to the outlet, but now tilting up to the north because of differential isostatic rebound. Moreover, rippled sand beds within these lacustrine deposits in the lee of Steamboat Rock indicates at least 14 current-emplaced sediment incursions - inferred as late and small Missoula floods - into this low-level glacial Lake Columbia, some separated by just three or four varves (Atwater, 1987, p. 188; Waitt, 1991).

Was this 470-m outlet elevation in Grand Coulee the controlling le el $\mathrm{f} r \mathrm{r}$ glacial Lake Columbia for the entire last-glacial period? Or was there significant lowering d’ung the period of Missoula flooding? And when did the retreating cataract complex of upper Gran $\mathrm{Co}$ lee break through to Columbia valley and lower the coulee entrance? These related questions n rise because stratigraphy and geomorphology indicate a fully deepened coulee early in the last-ola ' ${ }^{\prime a l}$ period. Yet flow modeling results suggest that upper Grand Coulee was not incised prior to las, slacial flooding of Moses Coulee and the Columbia valley to the west around its big bend. The tir..ng and magnitude of incision of upper Grand Coulee has been a persistent question, addressed ${ }^{\prime} B_{1} \star L(1932,1935$, p. 35-38), Richmond et al. (1965, p. 237239), Hanson (1970, p. 64, 69), Wa tt and Thorsen (1983, p. 57, 64), Atwater (1986, p. 36, 57), Balbas et al. (2017), and Waitt (in press) a. no ig others. It has implications relating to the various levels of glacial

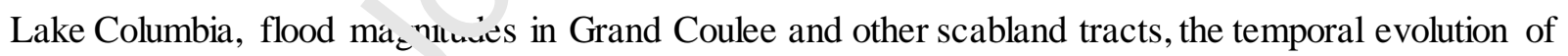
scabland tract erosion, and possibly routing of pre-last glacial floods.

Our renewed interest in upper Grand Coulee incision owes to recent flow modeling results (Denlinger et al., in press, discussed in more detail below) suggesting that a still-blocked upper Grand Coulee is required to funnel sufficient flow into the two flood tracts farther west-Moses Coulee, and the Columbia valley following the big bend. Both routes, as described below, passed large last-glacial floods, probably early in the overall Missoula flood sequence (Waitt, 2016, in press). If, however, upper Grand Coulee is open to its present depth and width, too much floodwater diverts south, leaving insufficient flow to 
produce the observed flood evidence in the western pathways. This conclusion implies that the cataract retreat creating upper Grand Coulee had not yet breached the Columbia valley or otherwise significantly lowered or widened the coulee entrance. This was similarly inferred by Hanson $(1970$, p. 64, 69) in concluding that large Moses Coulee floods preceded incision of upper Grand Coulee. Additional possible support of last-glacial cataract retreat in upper Grand Coulee are the cosmogenic exposure dates of floodexhumed granite in upper Grand Coulee and downstream granitic flood boulders in Quincy Basin. Both indicate last-glacial erosion of the basaltic and granitic rocks at the head Grand Coulee at $~ 17-15 \mathrm{ka}$ (Baker et al., 2016, p. 36-37; Balbas et al., 2017, p. 585).

Geomorphic and stratigraphic evidence, by contrast, suggests th t $\mathrm{t} u$,per Grand Coulee was open to near its present 470-m elevation near the beginning of the las $i$ gla ial period, at least for the duration of glacial Lake Columbia (Atwater, 1986, p. 37). The lacustrilıe silt and clay on the floor of upper Grand Coulee (Figure 10) and prominent terraces at $475-5.9 \mathrm{~m}$ extending up both the Columbia and Spokane River valleys show a long-lived last-glacial lakc raded to near the present 470 m-outlet elevation in Grand Coulee while the Columbia River was _till blocked by the Okanogan lobe (Figure 6Error! Reference source not found.f; Bretz ‘23 $^{\prime}$, p. 76, 78; Flint, 1936, p. 1868, plate 6; Jones et al., 1961, p 13, 77-78; Atwater, 1987; Kiver aı ${ }^{\top}$ Stradling, 1995, p. 128, 139-140). The evidence for short-lived glacial Lake Columbia levels as . $\mathrm{w}^{\prime} \mathrm{h}$ as $250 \mathrm{~m}$ higher than the present $470-\mathrm{m}$ Grand Coulee threshold is explained by the Okanoga $\cdot$ ku filling and blocking an already-incised Grand Coulee, signaled low in the Manila Creek section of glacial Lake Columbia deposits by four anomalously thin flood beds interpreted to indicate attenuated deposition in a deepened lake (Atwater, 1986, p. 22-23, 30-31, 34-35; 1987, p. 187). This scenario is consistent with evidence that the Okanogan lobe at its maximum extent did fill an already-deepened coulee.

One scenario possibly resolving the opposing interpretations is a hybrid one similar to that proposed by Waitt and Thorson (1983, p. 57): The earliest last-glacial floods did indeed erode the upper cataract complex back to the Columbia valley, but after or during the first few large floods that first passed 
through the Columbia valley and Moses Coulee to the west. Prior to the cataract complex reaching the Columbia valley, glacial Lake Columbia, once formed by the advancing Okanogan lobe, may have briefly stabilized at the $\sim 653 \mathrm{~m}$ head of Moses Coulee until it was overrun by ice, as shown in Figure $6 \mathrm{c}$. Once that outlet was covered and prior to full cataract retreat, any glacial Lake Columbia outlet would have been further east, perhaps a saddle where Grand Coulee is now, or one the divides just at 700-710 m leading to the Cheney-Palouse or Telford-Crab-Creek scabland tracts. The absence of strongly formed shorelines at high elevations indicates that any such stability was short-jived (and perhaps also affected by outlet erosion and the growing ice load). The lake and flood dynamics - in ngd markedly, however, when the upper Grand Coulee cataracts reached the Columbia valley, lor erit , and widening the opening to Grand Coulee. This later condition was likely the predominan+ -iru ' mstance-scores of Missoula floods entering a low-level glacial Lake Columbia and building str tig. ?phic records like that of the Manila Creek section over 2-3 ky, temporarily perturbed by he $J \mathrm{k}_{\mathrm{A}}$ nogan lobe reaching its maximum extent and filling the fully open Grand Coulee and deepe ing he lake.

Additionally, Kiver and Stradling (1995 . p. 15-16, 126-130, 139-140), propose at least some lastglacial incision of upper Grand Couler $\sim \epsilon_{\text {. }}$ lain the $\sim 30$ drop from an apparently stable "Lake Columbia II" stage at 510-535 $\mathrm{m}$ to the "Lak Columbia III" terraces at 475-490 m, which they correlate to the final $470 \mathrm{~m}$ Grand Coulee thresı ? $1 \mathrm{~d}$ (Kiver and Stradling, 1995, p. 17, 67, 124, 140), thus suggesting "significant changes in ba. ^ «.el" within upper Grand Coulee (p. 127). Such lowering, in part premised on distinct terrace levels we have observed near Hawk Creek as shown in Figure 8, is represented by the different glacial Lake Columbia levels ofError! Refe rence source not found. Figure 6e and f. Correlation of these terrace levels, however, is complicated by incomplete mapping, uncertain isostatic deformation, and absent geochronology. Moreover, it is uncertain if this minor amount of lowering could change flood flows sufficiently to produce the observed flood levels in Moses Coulee and Columbia valley. 
Considering the conflicting flow modeling results and stratigraphic interpretations, the timing, magnitude, and effects of upper Grand Coulee incision remains an important and unresolved questions for understanding last-glacial Missoula flooding. Nevertheless it is one possibly addressed with lidar-aided geologic and geomorphic mapping and stratigraphic and geochronologic studies focused on the history glacial Lake Columbia and Grand Coulee.

\section{Quincy Basin}

All floods passing through Grand Coulee entered Quincy Basin, which v. as at times was joined by floodwater entering from the east from Telford-Crab-Creek tract ar: "ve wirn strands of the CheneyPalouse tract (Figure 5). Floods from these varied source areas c 'vered Quincy Basin with bouldery fans and thick gravel and sand deposits (Bretz, 1923a, 1928a, p. 6, ‘`s3; Bretz et al., 1956, p. 969-974). The immense foreset-bedded deltaic gravel bar complex of Er ni ata fan, formed chiefly of basalt excavated from Grand Coulee, is $500 \mathrm{~km}^{2}$ broad and up tr $40 \mathrm{~m} \mathrm{l}$. $c k$ (Bretz et al., 1956, p. 969-974; Baker, 1973, p. 9, 15, 39-42). This deposit includes immense bu.lders, including an $18.5 \times 11 \times 8 \mathrm{~m}$ fragment of basalt entablature (Figure 11Error! Reference sr « re not found.; Baker, 1973, p. 23-29, 40-41).

Figure 11. Immense fragment of basalt intu' 'ature eroded from Grand Coulee and transported to the Ephrata fan where lower Grand Coulee opens into Quincy Bu in. Photograph by Jim E. O’Connor.

Maximum floods exı $` d$ Tuir cy Basin by four separate cataract-floored scabland channels - Crater Coulee, The Potholes, anc ${ }^{\top}{ }_{\star}$ enchman Coulee all went west into the Columbia valley; and Drumheller Channels south and then west to the Columbia by way of Lower Crab Creek or south into Pasco Basin through Othello Channels (Figure 5). The entrances to these four Quincy Basin overflow points all show very similar maximum flood stages of about $410 \mathrm{~m}$ (Table 3). Bretz (1928a, p. 670-673) made the case, restated in Bretz et al. (1956, p. 985), that this similar flood stage is implausible by sequential outlet erosion, but instead suggests simultaneous overtopping of Quincy Basin through all four exit spillways. This scenario requires rapid filling of Quincy Basin, compelling support for a huge flood (Baker, 2008, p. 39). Final smaller floods, or at least waning flow, as well as the diverted Columbia River through Grand 
Coulee between floods, incised through flood gravels on their way through Drumheller Channels into Lower Crab Creek (Bretzet al., 1956, p. 971-974), rejoining the Columbia River valley upstream of Sentinel Gap.

Balbas et al. (2017; Table DR2) report an average age of $15.6 \pm 1.3 \mathrm{ka}$ (mean \pm standard error) from seven granitic boulders in the Ephrata fan, tightly clustered between $15.0 \pm 1.2$ and $16.2 \pm 1.3 \mathrm{ka}$. These ages are similar to the exposure ages of unroofed granitic outcroppings in upper Grand Coulee. Flood gravel from pre-last-glacial flooding are also exposed in western Quincy $\Gamma_{\text {,asin, where two old floods left }}$ carbonate-cemented east-dipping foreset gravels derived from floods $s$ jillin ; east into the basin from the Columbia valley, opposite the direction of most if not all last-gla $i_{a}{ }^{1}$ flr ods (Bretz et al., 1956, p. 985; Bretz, 1969, p. 524; Baker, 1973, p. 8-9; Waitt, in press).

\section{Moses Coulee}

To the west, Moses Coulee is a slightly sm. 1er version of Grand Coulee. It leads south from the glaciated Waterville Plateau, entering the C('11mbia River valley south of Wenatchee (Figure 5). Bretz (1923a, p. 600-602) described its overall f rr 1 and setting, later elaborating some of the large flood bars and coulee features (Bretz 1928a, n 6 :?-675; 1930, p. 386-396). It was mapped thoroughly and described in the Ph.D. thesis $b_{j}$ Lar $_{j}$ G. Hanson (1970).

Moses Coulee encompa 'sts three distinct geomorphic settings over its 70-km path-two coulee segments separated by a broad and shallow scabland tract (Bretz, 1923a p. 600). The upper coulee emanates from the poorly defined Mansfield channels (Hanson, 1970, p. 52-53) into a distinct canyon near the Withrow moraine terminus of the Okanogan lobe. Here the coulee is $1-2 \mathrm{~km}$ wide and $150 \mathrm{~m}$ deep. The canyon walls diminish and lose definition over $15 \mathrm{~km}$ southward as it enters a structural trough. Here a plexus of scabland channels and cataracts - the Rattlesnake Springs (or "Three Devils") complex (Figure 12) — gathers into a deep gash cut across the Badger Mountain anticline, $800 \mathrm{~m}$ deep and $2 \mathrm{~km}$ across, and the coulee floor drops $140 \mathrm{~m}$ in $10 \mathrm{~km}$. Similar to Grand Coulee, Bretz (1923a, p. 600) 
inferred these cataracts formed by headward retreat from knickpoints initiated near the Badger Mountain anticline. Downstream of this cataract complex, Moses Coulee is a straight flat-bottomed trench for 21 $\mathrm{km}$ before joining the Columbia River valley $30 \mathrm{~km}$ downvalley of Wenatchee and $80 \mathrm{~km}$ below the maximum extent of ice in the Columbia valley near Chelan.

Figure 12. Oblique aerial view up Moses Coulee showing a portion of the Three Devils scabland complex. Bretz. (1923a, p. 600; 1930, p. 394-395) inferred these channels eroded by upstream cataract recession, as suggested by cataracts at the head of several channels. Photograph by Bruce Bjornstad.

Like Grand Coulee, Moses Coulee shows both flood and glacial fe turt . Scabland basalt emerges from the obscuring glacial margin at the head of the coulee, as we. as c ownstream where flow escaped the coulee confines within the structural trough leading into t's ' 'atilesnake Springs cataract complex at the head of the lower coulee segment. These erosional feat ses 1 . ticate the maximum flood stage descended from about $704 \mathrm{~m}$ near the Withrow mora ne : $\lrcorner 80 \mathrm{~m}$ where entering the cataract complex (Table 3). Flood bars near the coulee mouth to $\mathrm{o}^{\prime} \mathrm{i}$ at $280 \mathrm{~m}$ but maximum stages were undoubtedly much higher. The floods left large convex f $\mathrm{nd}$ bars studded with boulders in the coulee bottom (Bretz, 1928a, p. 673-675), systematically manne f $_{j}$ Hanson (1970, p. 43-47). One covers $3.8 \mathrm{~km}^{2}$ and stands $75 \mathrm{~m}$ above the valley floor. At M^ es ¿'oulee's mouth, a massive foreset-bedded boulder bar protrudes into the Columbia River valley 'Bre , 1930, p. 390-393; Bretzet al., 1956, p. 989-990; Hanson, 1970, p. 48-51; Waitt, 2016, p. 4.'1).

The Withrow moraine defines the maximum Okanogan ice lobe extent on the uplands east and west of the coulee. A prominent flood bar at the head of Moses Coulee is distinctly overlain by the terminal moraine where it drops into the coulee, showing that the flood bars and the coulee itself preceded the Okanogan lobe reaching its maximum extent. Braided outwash gravel surfaces descend down-valley from the terminal moraine, inset against and partly burying flood bars and locally filling the upper coulee segment with >60 m of gravel (Hanson, 1970, p. 40). The lower coulee has fill up to $100 \mathrm{~m}$ thick (Bretz, 1930, p. 395; Hanson, 1970, p. 41); most is likely outwash and concealed flood bars, but the upper several 
meters in the lowermost $\sim 10 \mathrm{~km}$ of coulee are bedded silts deposited by Missoula floods backflooding up Moses Coulee from the Columbia valley.

The most complete stratigraphic description pertinent to Moses Coulee flooding is for an up-Columbia remnant of the large Moses Coulee bar formed at the coulee mouth (Waitt, 1985a, p. 1275). Here, four up-Columbia-dipping basalt-gravel flood beds are separated by varved sequences containing as many as 37 silt-clay couplets. The basalt gravel beds must owe to Moses Coulee floods since sediment coming down the Columbia is basalt-poor (Bretz, 1930, p. 392). The varves sug ${ }^{\circ}$ st impoundment of the Columbia River valley, probably by the Moses Coulee flood-bar itself. The sequence of Moses Coulee flood beds and lacustrine sediment is capped by $11 \mathrm{~m}$ of fine sar 1 , nd ' ilt beds similar to Missoula flood slackwater deposits ubiquitous to downstream backflooded a eas 1 he beds are uncounted here, but another exposure we recently investigated at the north end of the Moses Coulee bar shows two basaltic gravel beds separated and overlain by sand-silt varw couplets. These couplets are overlain by at least 19 visible sand and silt beds and probably another 5 under cover. The stratified basalt-gravel beds and varves show the last two Moses Coulee flonds into a lake. These $\sim 34$ sand and silt beds probably owe to far travelled flood floodwater followin ${ }^{\text {th }}$ S Srand Coulee and Telford-Crab-Creek pathways farther east, entering the Columbia via Crab $\mathrm{Cr}{ }^{\curvearrowright} \mathrm{k}$ and Quincy Basin spillovers and backflooding $\sim 60 \mathrm{~km}$ up the Columbia valley, a scenario sho $\cdot n$; learly by recent flow modeling (Denlinger et al., in press).

This stratigraphy in conı nction with TCN dating aids understanding of the last glacial flood sequence involving Moses Coulee. Most likely is that Moses Coulee conveyed substantial Missoula-flood discharges only during blockage of Columbia River by the Okanogan lobe, enabling flood stages to overtop the $\geq 653$-m entrance divides, but prior to burial of the entrance paths at the head of the coulee by the advancing ice lobe (Waitt, 2016, in press). The stratigraphy at the mouth shows that at least four floods passed down Moses Coulee during this window. $\mathrm{A}^{36} \mathrm{Cl} \mathrm{TCN}$ age of $15.5 \pm 2.9 \mathrm{ka}$ on a basalt boulder on the surface of the flood bar near the head of the coulee may date the last large Moses Coulee flood (Keszthelyi et al., 2009, p. 861). Four ${ }^{10} \mathrm{Be}$ TCN ages of nearby granitic boulders on the Withrow 
moraine range from $17.1 \pm 1.4$ to $13.5 \pm 1.1 \mathrm{ka}$, mean 15.4 $\pm 1.4 \mathrm{ka}$ (Balbas et al., 2017, Table DR2), consistent with the clear geomorphic evidence that the maximum Okanogan lobe followed the last Moses Coulee flood. The fully advanced Okanogan lobe shunted floods to the more eastern flood paths (Figure 6Error! Reference source not found.c; Hanson, 1970, p. 83; Waitt, 2016), circuitously backflooding up the Columbia valley and depositing the $\sim 34$ fine-grained floodbeds in the lower coulee and overlying the bar at the coulee mouth.

The longer history of Moses Coulee and its relation to Grand Coulee $`$ main uncertain. As noted above, because the cols of the divides between the Columbia valley ar $1 \mathrm{M}$ ses Coulee are all above 653 m, Grand Coulee, its entrance upstream and 180-m lower at 470 m, wo dld have diverted much incoming Missoula floodwater. Consequently, Hanson (1970, p. 64, 79, co cluded that Grand Coulee could not have been incised to its present depth when Moses Coulos was conveying substantial flood water, a finding consistent with recent flow modeling discus $\cdot d$ beıw showing little water entering Moses Coulee if upper Grand Canyon is fully open (Denlinger - al., in press).

Also uncertain is the timing of the ovf ia : formation of Moses Coulee. All flood bars have last-glacial soils (Hanson, 1970, p. 76) and no ol er li od deposits are known. The Rattlesnake Springs cataract complex appears fresh and probai ${ }^{\prime} \mathrm{V}$, as the major source of the immense flood bar at the coulee mouth. Yet flood flows within the ' ppu "and lower coulee segments were fully contained, indicating a preexisting drainageway. And $\iota$ e margins of the lower coulee are deeply notched by large tributary drainages, some closely at grade, giving the appearance of a long-established drainageway (Bretz, 1923a, p. 601; Bretz, 1930, p. 395-396; Hanson, 1970, p. 26-27). It likely that Moses Coulee was carved during previous advances of the Okanogan lobe and blockage of the Columbia valley, but the specifics and timing remain unknown. 


\section{Columbia River sans Okanogan Lobe}

At least one last-glacial Missoula flood came down the mainstem Columbia River valley around the big bend, emplacing large bars, high eddy deposits, and ice-rafted erratics along the $90-\mathrm{km}$ reach between Chelan and the entrance of Moses Coulee (Figure 5). Although its distinctly more felsic and sandy deposits were recognized by Bretz et al. (1956, p. 986-987), they were not attributed to Missoula flooding until Quaternary geologic mapping in the Chelan and Wenatchee areas in the 1970s by Richard Waitt (1982, 1987), reported in a 1977(a) abstract titled "Missoula flood sans ' 'ranogan lobe."

High eddy bars and tractive bars can be traced from near Chelar " thu down-Columbia maximum extent of the Okanogan ice lobe near Chelan to beyond the moui of Moses Coulee (Waitt, 2016, 2017, in press; Hendrick et al., 2017). They stand above the prominen wash terrace descending south from the maximum ice extent (Figure 8, Figure 13). Two huge 1 ar, c t Brays Landing and Pangborn are covered with giant current dunes. Pangborn bar, just do vns rea. ? of Wenatchee and covering nearly $40 \mathrm{~km}^{2}$, is one of the largest individual Missoula floc ${ }^{-1}$ bars. the bars have distinctly sandy and quartzo-feldspathic compositions in contrast to the basaltic $\mathrm{g}$ ar $\mathrm{e}$ ' deposits within and downstream of the eastern scabland channels (Bretzet al., 1956, p. 986- ? 37). These flood deposits may correlate to bouldery foreset gravels and coarse sands underlying till oi the Okanogan lobe exposed along the Columbia valley upstream of the Okanogan River confluence, als । indicating a pre-Okanogan lobe flood (Hibbert, 1985, p. 96, 107), as well as the coarse flood depc ;its at the Spokane and Columbia river confluence inferred by Kiver and Stradling (1995, p. 119) to precede glacial Lake Columbia. Maximum flood stages for this downColumbia flood were 250-300 m above river level, indicated by ice-rafted erratics as high as $495 \mathrm{~m}$ near Wenatchee (Figure 8; Waitt et al., 2019), descending to stripped basalt, erratics, and an eddy bar as high as $420 \mathrm{~m}$ on Babcock Bench, $45 \mathrm{~km}$ downstream (Table 3).

Figure 13. Last-glacial flood and outwash features in the Brays Landing area mapped onto hillshade digital elevation model derived from 1-m resolution lidar. Immense, bouldery, current-dune covered Missoula flood bar in point-bar position extends six km downstream from eroded granite outcrops and climbs to $260 \mathrm{~m}$ above historical river level. This bar was deposited by 
Missoula flood(s) preceding blockage of the Columbia River by the Okanogan lobe. Inset against the bar complex is the mostly planar, downstream sloping cobble-gravel terrace graded to the maximum extent of a down-Columbia finger of the Okanogan lobe that terminated about $7 \mathrm{~km}$ upstream from the right figure edge. Inset against the outwash terrace is another boulderarmoredflood bar, its surface mostly disturbed by housing, but still preserves a few obvious giant current dunes. This lower bar probably owes to the outburst of glacial Lake Columbia at about $14.5 \mathrm{ka}$. Associated flooding may have channeled the outwash terrace above. Figure outline shown on Figure 5. Lidar obtained from the Washington Lidar Portal (https://lidarportal.dnr.wa.gov).

This flood (or floods) preceded the maximum advance and long-lastir $\mathrm{g}$ blockage of the Columbia River valley by the Okanogan lobe. Weakly developed capping soils c 1 th de deposits show it to be last glacial (Waitt, 1982, 1987; Waitt et al., 2019). Three $\mathrm{TCN}^{10} \mathrm{Be}$ ag ss of high ice-rafted erratics gave ages

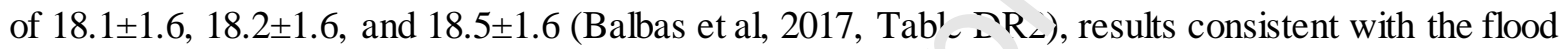
preceding the Okanogan lobe blockage of the Columbia val' $y$ y a.'d formation of glacial Lake Columbia.

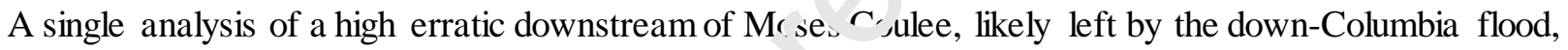
gave an age of $23.0 \pm 1.9 \mathrm{ka}$, possibly affected $\longleftarrow$ : $r$ ior exposure.

This reach, like the Cheney-Palouse tr $\sim t, c \cdot$ ntains evidence of pre-last-glacial floods. A foreset bedded gravel capped with a 4-m-thic's $\mathrm{r}^{2}$ tlucalcic horizon underlies a small pendant bar outboard and above Pangborn bar (Waitt, in press), At least two floods spilled out of the Columbia valley and east into Quincy basin by way of Pothrles ` Julee (Bretz et al., 1956, p. 985; Bretz, 1969, p. 524; Baker, 1973, p. 8-9). Additionally, as disc ssea below in the "Other Last-Glacial Floods" section, at least two floods in this reach postdated the Okanogan lobe blockage of the Columbia (Waitt, 2016).

\section{Pasco Basin and Wallula Gap}

All Missoula floods passed through broad Pasco basin before funneling through Wallula Gap, the tight valley constriction at its outlet (Figure 5). The Pasco basin is a structural and topographic trough of about $4000 \mathrm{~km}^{2}$ of south-central Washington. The Columbia River enters from the northwest through Sentinel Gap, cut through the Saddle Mountain anticline. The river continues southeast into the basin, joined by 
the Yakima River from the west and by Snake River and Walla Walla Rivers from the east. Thus bolstered, the Columbia River exits the basin southward through Wallula Gap, incised through the Horse Heaven Hills-another narrow anticline. From here the river turns west towards Umatilla basin and the Columbia River Gorge, and the Portland Basin.

Missoula floodwater entered the Pasco basin by way of the Columbia River valley (including flow entering from Quincy basin and Crab Creek), from the Snake River valley (mainly supplied by the Cheney-Palouse scabland tract), from Washtucna Coulee and Equatzel C'- dlee from the northeast (also mostly from the Cheney-Palouse tract), and the Othello Channels fron the rorth (mainly from Quincy basin). All flow exited through Wallula Gap, $2 \mathrm{~km}$ wide at its narc ves . and $275 \mathrm{~m}$ deep. This narrow gap, and some downstream in the Columbia River Gorge, im sedt 1 tlood flow out of the Pasco basin. This hydraulic ponding backflooded Pasco Basin tributary valloys like Yakima valley to the west (Bretz, 1930, p. 412-420) and Walla Walla valley to the east ( $\operatorname{Rrc} \cdot 7,1 y<9 b$, p. 516-536). This passing wave of ponded flood water is sometimes confusedly referred tu - "glacial Lake Lewis" (after Captain Merriweather Lewis), a name proposed by Symons (1882 \% 108) to explain the ubiquitous ice-rafted boulders, gravel deposits, and bedded silt.

High ponded flood stages in F s sce basin are marked by thousands of ice-rafted erratics beached on flanking hillslopes (e.g. Bre.L, :93v, p. 409-410), the highest yet found is $366 \mathrm{~m}$ (Bjornstad, 2014, p. 54). This elevation accords with . he highest divide crossing (347 m) and loess scarps (up to $360 \mathrm{~m}$ ) at the Wallula Gap outlet, $270 \mathrm{~m}$ above the Columbia River's natural level (Table 3). A transient flood stage of $360-366 \mathrm{~m}$ would inundate $13,000-14,000 \mathrm{~km}^{2}$ of eastern Washington with $1300-1400 \mathrm{~km}^{3}$ of water (Table 1), backflooding far up the Columbia and Snake valleys. The transiently impounded volume is more than half the total volume of a maximum glacial Lake Missoula.

Floods slackened as they entered the expansive Pasco basin, depositing broad bars of sand and gravel along major flow routes. The largest, Cold Creek bar, covers more than $30 \mathrm{~km}^{2}$ (Bretz, 1928a, p. 679681; Bretz et al., 1956, p. 1009-1015; Bjornstad et al., 1991). Away from main flow routes, at higher 
elevations, and in back flooded tributaries, finely bedded sand and silt drape pre-flood topography (Bretz, 1925a; 1929a, b; 1930). These were named the "Touchet Beds" by Flint (1938, p. 493-495, 503-504).

The Touchet Beds, commonly termed rhythmites because of their repetitive couplets of sand and silt, have long been a focus of Missoula flood controversies (Figure 14). Bretz(1925a; 1929a, b; 1930) mapped the extent of a "widespread mantle of silt" (1929a, p. 393), which he inferred to be slackwater flood deposits composed of reworked loess eroded from scabland channels, though puzzled by the "varvelike arrangement of silt and fine sand" (1929b, p. 533). Flint (193?" and Allison (1941) cited the bedded silts to invoke ponding under alternative explanations for scab and eatures, inferred formed in the aggrading and then incising fill of a long-lived Lake Lewis damre ${ }^{\top}$ bv downstream blockages. In Bretz's final (1969) Missoula flood paper, he affirms the rhythmites as lc sss-derived slackwater deposits laid by water hydraulically ponded behind Wallula Gap, in part hased on evidence of deposition by upvalley currents (Bretz et al., 1956, p. 1034), but he wavere on uneir significance: "There are altogether too many in one section, and they are too thin to assign ea 1 couple to a separate flood influx. Thicknesses of the total deposit seem too great, however, to assis. to one flood."

Figure 14. Nearly 40 beds of Missoula fln d su-kwater deposits exposed in 30-m-deep Burlingame Canyon within the Walla Walla River valley. This section has been a. `lyzed by Bjornstad (1980), Waitt (1980), Moody (1987), and Clague et al. (2003), and was the key site supporting Waitt s 19:0) hypothesis that each bed was laid down by individual floods decades apart, thus indicating dozens of Missoul floc 's. P otograph by Bruce Bjornstad.

Such a "separate flood influx" interpretation was soon put forward. Waitt coming across the spectacular Burlingame Canyon exposure in 1977, concluded from it and similar rhythmite sections in the Yakima and Walla Walla valleys that each layer was indeed from a separate deluge, each "followed by decades of normal subaerial environments" (Figure 14; Waitt, 1980, p. 655). Thirty-nine layers at Burlingame Canyon suggested about 40 floods, matching counts of similar beds far downstream at the River Bend section in the Willamette Valley (Figure 1; Glenn, 1965) and 40 rapid drainages inferred at the Ninemile exposure of glacial Lake Missoula bottom sediment (Alt and Chambers, 1970; Chambers, 
1971). This evidence came together as the controversial jökulhlaup concept of scores of Missoula floods from a self-dumping glacial Lake Missoula (Waitt, 1980, 1984, 1985).

The question of whether the Touchet Beds represented just a few or several dozen Missoula floods lived on for 40-plus years (e.g. Bretz, 1969; Bjornstad, 1980; Waitt, 1980, 1984, 1985a; Bunker, 1982; Baker and Bunker, 1985; Moody, 1987; Smith, 1993; Shaw et al., 1999, 2000; Atwater et al., 2000; Clague et al., 2003; Hanson, 2013). Nevertheless, abundant and diverse evidence — tephra falls, paleomagnetic secular variation, mammal and insect recolonization — sh" $\mathrm{s}$ that that most individual rhythmites in Pasco Basin and tributary valleys were indeed emplacec by in dividual Missoula floods years to decades apart (e.g. Waitt, 1980, 1985a; Spencer, 1989; Sn.th, 993; Clague et al., 2003; MacEachern and Roberts, 2013). Still, questions remain, suc 1 ho $v$ do the extensive rhythmite sections correlate with the stratigraphic records in glacial Lake $C \sim_{1} l_{1}$ nbia, Lake Spokane, and Lake Missoula, and even those offshore? And what was the genesis of $\mathrm{u}^{\prime}$ ' 'onı urmities in some of the Walla Walla valley sections, particularly evident at the Cummings : Idge section (Moody, 1987, p. 307-308; Bjornstad et al., 1991, p. 706-707), but also noted elsewhere (.'nencer and Jaffee, 2002)? Can clues in the slackwater

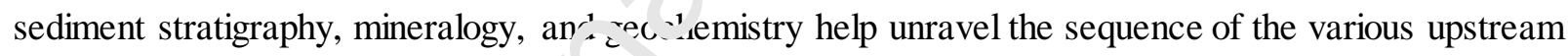
flood routes and their changes with ime.

In addition to addressing ın number of floods, the extensive deposits in the Pasco Basin attract efforts to determine the timing of la t-glacial flooding. Many results are variously tabulated in Bjornstad et al., (1991, p. 230); Hanson (2013, p. 199-203), Baker et al. (2016, p. 11), and Waitt (2016, p. 439). Most dating has been by radiocarbon but OSL and TCN techniques are now being applied (Baker et al., 2016, p. 11; Bjornstad, 2014; Balbas et al., 2017). Key radiocarbon ages (calibrated to calendar years) from within deposits include a 17.9-17.6 ka mammoth bone from within high-elevation rhythmites in the Yakima valley (Lillquist et al., 2005), 18.3-15.9 ka and 16.6-14.6 ka shells within lower Yakima valley rhythmites (Waitt, 1985a; Baker and Bunker, 1985). High-elevation rhythmites in the Walla Walla valley 
are overlain by a soil containing molluscs dated at 15-14.3 ka, calibrated from ages reported in Spencer and Knapp (2010).

Clague et al. (2003) examined the stratigraphy and paleomagnetic secular variation of three floodrhythmite sequences in the Yakima and Walla Walla valleys, including the Burlingame section (Figure 14) previously analyzed by Waitt (1980) and Bjornstad (1980). From the magnetic variation and presence of Mount St Helens Set S (So-Sg) tephra couplet, Clague et al. (2003) developed a correlated stratigraphy among the three sites encompassing 31 flood beds below the tephra $\operatorname{cou}_{1}{ }^{1}, t$ and 22 beds above. They concluded from the secular variation that the individual flood beds we e las 1 down decades apart and the entire sequence deposited over a few thousand years. Moreover, by cor paring the variation to a reference curve derived from dated lacustrine sections in Oregon and ( alit rnia, they propose two possible correlations: (1) For the 10 flood beds below the tephra nnd the $1 j$ above (for which they had measurements at multiple sites), the statistically hes: matun indicates an interval of $60 \mathrm{yr}$ between couplets and a tephra age of $13,350{ }^{14} \mathrm{C}$ yr BP, $\mathrm{c}$ - divalent to 16.2-15.9 ka. (2) Considering the entire section and possibly varying intervals betwee. floods, the best correlation predicts a $14,400{ }^{14} \mathrm{C}$ yr BP age estimate for the tephra, equivalent to $17.7-: 7.4 \mathrm{ka}$, and a $\sim 20.5-15.5 \mathrm{ka}$ range for all 53 beds. Both scenarios are plausible but the firsı vetter fits the $\sim 16$ ka age for the Set $S$ tephra couplet suggested by Clynne et al. (2008, p. 619).

TCN ages from the Pasc. Basin are broadly consistent with the radiocarbon and magnetic variation results. Keszthelyi et al. (2009, p. 861) report four ${ }^{36} \mathrm{Cl}$ TCN ages for ice-rafted erratics on slopes surrounding Pasco Basin. Three for erratics mapped by Bjornstad (2014) on Rattlesnake Mountain give ages ranging from $16.9 \pm 3.4$ to $16.2 \pm 1.3 \mathrm{ka}$. The fourth age from a large erratic at Badger Coulee is 35.6 $\pm 2.1 \mathrm{ka}$, possibly affected by prior exposure. Two erratics on the high western rim of Wallula Gap have ${ }^{10} \mathrm{Be}$ TCN exposure ages of $18.2 \pm 0.8$ and $66.0 \pm 5.8 \mathrm{ka}$, the older also discounted because of likely inheritance (Balbas et al., 2017, Table DR2), the younger has an age consistent with it being floated on a down-Columbia flood before the Okanogan lobe blocked the Columbia valley. 
OSL age ranges of Pasco Basin flood deposits range wider. Keszthelyi et al. (2009, p. 856-857) report ages between $21 \pm 2$ and $12 \pm 2$ ka for a sequence of low-elevation flood beds near the center of Pasco Basin. Hanson (2013, p. 99) gives ages of $14.1 \pm 0.8$ ka and $5.7 \pm 1.6$ ka just above and below the Set $S$ tephra, respectively, from a sequence of flood beds in Yakima valley.

Flow exited Pasco Basin through Wallula Gap, a narrow constriction flowing 270-m-deep during maximum floods. It has been a focal point for discharge estimates (Table 2), starting with a calculation by D.F. Higgins in Bretz (1925b, p. 257-258). The maximum flow stage el ${ }^{` c}$ ring the constriction was about $360 \mathrm{~m}$ (O'Connor and Baker, 1992), descending to $340 \mathrm{~m}$ near The D. lles Table 3). Also important is evidence that the constriction was nearly as wide and as deep as $t_{2}$ no $N$ during the time of peak flood stage, judging from a gravel bar emanating from a high divid : cr ssing the west shoulder of the gap and descending to the canyon bottom just downstream of the narrowest part of the constriction (Bretz, 1969, p. 535). This evidence indicates the present geometi, of ue constriction has not enlarged substantially since peak flow, thereby reducing the uncertain.' in discharge estimates owing to canyon widening and deepening after emplacement of maximum-stace evidence.

\section{Columbia River Gorge and Pc tlaı.d Basin}

Downstream of Wallula $\mathrm{G}_{\mathfrak{1}}$, the Columbia River flows through a series of basins and canyons, including the 1000-m-d $>\mathrm{p}$ Tolv nbia River Gorge where the river crosses the volcanic arc of the Cascade Range. West of the Casca ${ }^{`}$ Range, floods entered the broad Portland basin, hydraulically ponded here behind constrictions farther downstream.

Where the floods coursed through this long-established valley, the erosional features are not as dramatic as in the Channeled Scabland. Nevertheless, large bouldery gravel bars, high eddy deposits and divide crossings, scabland tracts, ice-rafted erratics, and rhythmically bedded slackwater deposits are common for the $300 \mathrm{~km}$ between Wallula Gap and the Portland basin (Bretz, 1924, 1925b, 1928a; Hodge, 1931, 1938; Allison, 1933, 1941; Newcomb, 1969; Allen et al., 2009; O’Connor and Waitt, 1995; Benito, 
1997; Benito and O'Connor, 2003; O’Connor and Burns, 2009). Floods entering the broad Portland Basin deposited a $\sim 400 \mathrm{~km}^{2}$ complex of bars, now under the cities of Portland, Oregon, and Vancouver, Washington (Bretz, 1925b, 1928a; Trimble, 1963; Allison, 1978; Evarts and O'Connor, 2008; Evarts et al., 2009). Impounded by downstream constrictions, the floods backflooded $200 \mathrm{~km} u p$ the Willamette Valley (Figure 1) to the present site of Eugene, Oregon (Allison, 1935; Glenn, 1965; O'Connor et al., 2001; Minervini et al., 2003).

As marked by erratics and divide crossings, the maximum flood stage escended from about $360 \mathrm{~m}$ upstream of Wallula Gap to $120 \mathrm{~m}$ in Portland basin (Table 3; Benitc and O'Connor, 2003, p. 634). Most of this fall was in the 130-km-long Columbia River Gorge ' $x$ ver $\mathrm{n}$ The Dalles and Portland, where maximum flood stages descended from 340 to $120 \mathrm{~m}$.

The barely detectable descent of maximum stages- $-\mathrm{O}^{r}$.1 $~ ~ 20 ~ m$ over $200 \mathrm{~km}$ between Pasco basin, through Wallula Gap, and to the head of the Cr.un bia River Gorge near The Dalles - prompted Ira Allison's hypothesis "that the ponding was produ - $d$ by a blockade of ice in the Columbia River [Gorge]" instead of a "large, short-lived catastroph cc 'ou'" (Allison, 1933, p. 676-677). Hydraulic modeling by Benito and O'Connor (2003) and De* ling * and O’Connell (2010) shows, however, that tight constrictions in the Columbia Riv $r$ C'rge hydraulically ponded floodwater upstream to Wallula Gap and beyond, further raising flow sta res in Pasco basin. For the largest floods, flow was likely hydraulically "critical" through some of $\mathrm{t}_{\mathrm{L}}$ ? narrow constrictions of the Columbia River Gorge.

Stratigraphic studies in the Columbia River Gorge by Benito and O'Connor (2003) were motivated by the relatively simple hydraulic conditions - a single flow route through an existing minimally eroded valley hydraulically controlled downstream by tight constrictions. This situation enables evaluation of the geologic effects and deposits of the floods relative to local hydraulic conditions (Benito, 1997). Evaluating evidence of multiple floods in combination with 25 radiocarbon analyses (mostly reworked organic materials), Benito and O'Connor (2003, p. 637) concluded that at least 25 floods had discharges exceeding 1 million $\mathrm{m}^{3} / \mathrm{s}$, and at least six or seven topped 5-6 million $\mathrm{m}^{3} / \mathrm{s}$, two postdating the Set $\mathrm{S}$ 
tephra. At least ten floods had discharges less than 3 million $\mathrm{m}^{3} / \mathrm{s}$, all likely younger than Set $\mathrm{S}$. The largest floods(s) of about 10 million $\mathrm{m}^{3} / \mathrm{s}$ post-date humates from a soil clast that gave a calibrated age of 23.4-22.5 ka. Dates from detrital organic materials in gravel flood bars are as young as 16.9-16.2 ka. A solitary ${ }^{10} \mathrm{Be}$ TCN age of $34.1 \pm 2.6 \mathrm{ka}$ for an ice-rafted erratic in the Columbia River Gorge is inferred too old because of inheritance (Balbas et al, 2017, Table DR2).

Stratigraphy in the Portland Basin and adjacent backflooded valleys is like that in the Pasco Basin but correlation is handicapped by being outside the Set S tephra plume. Witı. : the $1200-\mathrm{km}^{2}$ Portland Basin the distribution of flood deposits is summarized by Evarts et al. (2009, and shown on the geologic map compilation of Wells et al. (2020). The distribution of ice-rafted 21 ' atic , which reach heights of $120 \mathrm{~m}$, is shown by Allison (1935) and Minervini et al. (2003). Depos: s in lude broad channelized sheets and bars of foreset-bedded gravel in areas of main currents, and hatued silt and sand in areas of slacker currents. The most complete stratigraphic records obtained sc far 11 this area are from the backflooded Willamette valley. In the northern Willamette valley, depos. as thick as $30 \mathrm{~m}$ underlie the valley bottom at elevation 50-60 m except where eroded by post-flood i rers, pinching out on adjacent slopes as high as $120 \mathrm{~m}$ (O’Connor et al., 2001, p. 20). Glenn (196, p. 88) counted 40 flood beds at the River Bend section, but the number of beds diminishes to $\mathrm{t}_{\text {.' }}$ south and up-valley (O'Connor et al., 2001, p. 22). An uncounted sequence of later Missoula flon te osits appears inset into the main valley fill (O'Connor et al., 2001, p. 25).

Here too geochronologic information comes mostly from radiocarbon dating supplemented by tephra stratigraphy, magnetostratigraphy and a few OSL determinations. In the northern Willamette valley the thick sequence of flood beds overlies Willamette River gravel and capping soil dated 26.6-26.0 ka (O’Connor et al., 2001, p. 25). Megafauna bones collected from postflood bogs are as old as 14.5-14.1 ka (Gilmour et al., 2015, Table 1, UCIAMS78132 X). They also report an older post-flood megafauna bone age of 15.1-14.4 ka from the subsidiary Tualatin valley (UCIAMS78124 X). These Willamette valley post-flood ages are consistent with a less-precise 16.6-14.6 ka age reported by Mullineaux et al. (1978, p. 
178) from peat, as well as ages of 14.0-13.8 ka and 13.8-13.6 ka reported by Archaeological Investigations Northwest (2015) for post-flood deposits in the northern Portland Basin. Three OSL ages from a sequence of slackwater flood beds in the Tualatin valley give ages ranging from $19.7 \pm 2.5 \mathrm{ka}$ to 16.1 $\pm 1.3 \mathrm{ka}$ (Wells et al., 2020).

Hanson (2013, p. 79-129) examined the magnetostratigraphy of the lowermost 19 beds of the 40-bed River Bend section studied by Glenn (1965) and a better exposed section 750 m north. Adopting a similar procedure and reference curve as Clague et al. (2003), the best-fit correl $+{ }^{*}$ on "indicates that the 19 floods span approximately 600 years between 13.7 and $13.1{ }^{14} \mathrm{C}$ ka BP," whi h ca ibrates to $16.7-16.3 \mathrm{ka}$ to 15.9-15.6 ka. Because the base of the flood beds is exposed here ('len' ., 1965, p. 65-99; O'Connor et al., 2001, p. 17), and the magnetostratigraphy is from the base of the ection, this age range should encompass the earliest floods of the last-glacial flood enis nue.

Overall, the geochronology for the Columbir n ve, Gorge and the Portland Basin is like that upstream, especially as estimated from the radiocarbon dates All or most floods were subsequent to $23 \mathrm{ka}$ and had concluded by about $14.5 \mathrm{ka}$. Floods both $\mathrm{rr}$-eaed and post-dated the $\sim 16 \mathrm{ka}$ Set $\mathrm{S}$ tephra. Larger floods preceded smaller floods. No deposits of $\mathrm{o}_{\mathfrak{\aleph}}{ }^{\mathrm{e}} \mathrm{er}$ cataclysmic flooding have been found in the Columbia River Gorge or Portland basin, th^ ' $g_{\perp}$. Cordero (1997) attributes unconformities in a loess sequence in eastern Columbia River Gor ge . ר pre-last-glacial flooding (also described in Medley, 2012, p. 109-112; 115-116).

\section{The Eastern Pacific Ocean}

Down-Columbia floods jetted out of the western Columbia River Gorge, ponded in the Portland Basin, and exited northwest through Kalama narrows (Evarts et al., 2009, p. 8). They then continued down the Columbia valley to the Pacific Ocean (Figure 1). Missoula flood deposits are scarce downstream of Portland but traceable to Longview at Columbia River Mile 67, where backflooding up the Cowlitz valley deposited rhythmites and erratics as high as $60 \mathrm{~m}$ (Table 3). Downstream of Longview, flood deposits are 
likely below the modern estuary level, buried by Holocene valley fill accumulated during post-glacial sealevel rise. Such fill extends $130 \mathrm{~m}$ below sea level at the present Columbia mouth (Baker et al., 2010), and is about $70 \mathrm{~m}$ deep $170 \mathrm{~km}$ upstream near Portland (Peterson et al., 2011).

In the eastern Pacific Ocean, however, extensive areas of Columbia-basin flood deposits are revealed by ocean-floor cores (Griggs et al., 1970; Brunner et al., 1999; Zuffa et al., 2000; Normark and Reid, 2003; Hendy, 2009; Cosma and Hendy, 2008; and Gombiner et al., 2016). Floods and accompanying turbidity currents entered the eastern Pacific by way of the submarine $\mathrm{W}$ " apa and Astoria Canyons (Beeson et al, 2017), built up the Astoria Fan (Prytulak et al., 2006), a 'd cc ntinued $~ 1500 \mathrm{~km}$ down the Cascadia Channel to the abyssal plains of the eastern Pacific Ocra. (B unner et al., 1999; Normark and Reid, 2003). These deposits — sandy turbidites from sedimen -lac n density flows — are also composed of multiple fining upward sequences; 20 late Pleistocene turbıdite lıegabeds in the Escanaba trough decanted off the Cascadia Channel, including one bu 15 \% in thick (Zuffa et al., 2000, p. 257, 264; Normark and Reid, 2003, p. 621). About 400 kı. northwest of the Columbia mouth, core MD02-2496 on the continental slope off the coast of Vancnuv - $r$ Island also records many flood beds (Cosma and Hendy, 2008). Counting and provenance asse ne. ${ }^{*}$ oy Gombiner et al. (2016) show 44 beds to be from the

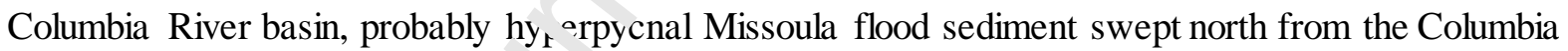
River mouth by the California L.rrr.nt.

Columbia Basin megaflu d chronology in the eastern Pacific chiefly derives from radiocarbon-dated cores ODPH 1037B (Zuffa et al., 2000, p. 256) and MD02-2496 (Cosma et al., 2008; Gombiner et al., 2016). Within the ODPH 1037B core in the Escanaba Trough (encompassing units B and C of Zuffa et al, 2000), a radiocarbon date of $25,700 \pm 100$ (planktonic foraminifera) that calibrates to $29.3-28.5 \mathrm{ka}$ underlies all 20 flood beds by about $80 \mathrm{~m}$. Within the flood-bed sequence are three radiocarbon ages that give calibrated ages, bottom to top, of 18.8-18.4 (planktonic foraminifera), 19.2-19.0 (pinecone 
fragment), and 12.9-12.5 ka (planktonic foraminifera) ${ }^{5}$. The three dates from planktonic foraminifera have an additional uncertainty of a specified reservoir correction factor that has likely varied over time (e.g. Cosma et al., 2008, p. 943). The 57-m thick bed is between the two older ages, thus about 19 ka if the ages are valid. About three flood beds overlie the 12.9-12.5 ka date. Chronology for the MOD022496 core off Vancouver Island is detailed in Cosma et al. (2008). From this chronology and the core stratigraphy, Gombiner et al. (2016, p. 135) counts 44 flood beds emplaced over $\sim 4400$ yr between 19.3 and $14.9 \mathrm{ka}$ and having a periodicity of 50-80 yr. Both sites likely lack records of smaller Missoula floods from late in the flood sequence.

Late Pleistocene freshwater pulses - perhaps owing to megaf' $x^{{ }^{1} \mathrm{~s}}-$ are also detected in eastern Pacific Ocean cores by proxy measures of salinity. From a p ir o: cores, Lopes and Mix (2009, p. 78) detect peak episodes of freshwater influence at $17.5 \mathrm{ka}$. ${ }^{n \mathrm{ka},} 23 \mathrm{ka}, 27 \mathrm{ka}$, and $30.5 \mathrm{ka}$. They attribute the youngest freshwater pulse at $\sim 17.5 \mathrm{ka}$ to Missol: flouding, but it could also owe to the $\sim 18 \mathrm{ka}$ Bonneville flood, which released twice the volu $-\div$ of the largest Missoula flood. The earlier freshwater peaks, like the large 23 ka pulse, likely relate $\mathrm{n}$ increased runoff or outburst floods during expansion of a still far-north Cordilleran ice sheet. $M_{u_{2}} \mathrm{r}_{\boldsymbol{L}}$ ently, Praetorius et al. (2020) summarize records from ten cores in the northeastern Pacific, fh. ling sustained freshening of surface waters between 19.0 and $16.5 \mathrm{ka}$ and accompanying increases in ( $^{\text {er }}$, water radiocarbon age, indicating suppressed ventilation of abyssal waters. Moreover, their o ${ }^{2} a_{1}$ _ rrculation modeling of megaflood and ice-sheet runoff into the Pacific during this period suggests tar-ranging oceanic cooling from freshwater input from the Columbia River basin, possibly triggering oceanic circulation changes.

Normark and Reid (2003, p. 634) estimated a total volume of last-glacial flood deposits in the eastern Pacific Ocean as $1450 \mathrm{~km}^{3}$, including about $700 \mathrm{~km}^{3}$ from a single flood leaving the $57-\mathrm{m}$ thick bed in the

\footnotetext{
${ }^{5}$ The three radiocarbon ages of planktonic foraminifera reported here from Zuffa et al (2000, p. 258) are calibrated using CALIB 7.1 (Stuiver et al., 2020) using the MARINE13 calibration curve and a marine reservoir correction factor delta $\mathrm{R}$ of $437 \pm 50$, as indicated by the closest determination included in the $14 \mathrm{CHRONO}$ database at http://calib.org/marine/.
} 
Escanaba Trough (but not including the deposits assessed by Gombiner et al., 2016). Assuming a 50\% porosity for this sandy unit implies that the entrained sediment volume for this large early flood was about $15 \%$ of the maximum plausible total water volume of $2500 \mathrm{~km}^{3}$, the approximate maximum released volume of glacial Lake Missoula. Thus, this flood (and likely dozens of others) was exceptionally turbid.

\section{Missoula Flood Timing Synopsis}

Distillation of the broad and varied work on the timing of events associated with the Missoula floods leads to some general conclusions as well as continuing uncertainties ( $\mathrm{e}$ - b. ker et al., 2016, p. 10-13; Waitt, 2016, p. 438-440). Glacial Lake Missoula was extant and pr un ? lug floods for at least 3-4 ky during 20-14 ka, as evident from the glacial chronologies, the lac 'strine records of glacial Lakes Missoula and Columbia, and from dating of flood deposits alo. - ihe flood route. The lake was gone by the time of the 13.7-13.4 Glacier Peak tephra fall. Doz $r_{s}$ ( f floods preceded, and dozens post-dated the 16 ka Mount St Helens Set S tephra fall. Mos. flo ds untered glacial Lake Columbia, impounded by the Okanogan lobe for 2-5 ky, most likely bet veen abuut 18.5 and $15 \mathrm{ka}$. Glacial Lake Columbia outlived the last flood from glacial Lake Missoula by $\mathrm{m}^{\prime}$, than 200-400 yr. At least one flood came down the Columbia valley before Okanogan is blockage at about 18.5-18 ka. This flood (or floods) and the four or more Moses Coulee floods that sou nullowed were the earliest floods of the last glacial sequence. At least 20 floods down the $\mathrm{Cl}$ eney Palouse tract were after the 18.3-18 ka Bonneville flood and at least seven recorded in the Tucan on valley were after the $\sim 16 \mathrm{ka}$ Set $\mathrm{S}$ tephra. For a few centuries during the time of glacial Lake Columbia, glacial Lake Spokane was apparently impounded by the upstream Columbia ice lobe, long enough to receive about 15 flood beds in backflooded Latah Creek valley. The period 17-15 ka coincided with the maximum extent of the Okanogan and Purcell Trench lobes, many Missoula floods (particularly in the Cheney-Palouse tract and Grand Coulee), substantial erosion and possibly deepening of upper Grand Coulee, and widespread tephra falls from Mount St. Helens eruptions.

Some timing inconsistencies, issues, and opportunities include the following: 
- The local evidence of mid-Wisconsin floods (e.g. Kiver et al., 1991, p. 241-243) appears inconsistent with the established glacial chronology and formation of glacial Lake Missoula. Because this evidence is at least partly based on radiocarbon dating of detrital organic materials, it may be a consequence of old carbon. Such reworking was called upon to explain the very first reported radiocarbon age for scabland flooding - a $32,700 \pm 900{ }^{14} \mathrm{C}$ yr age from a clast of peat that Fryxell (1962, p. 118) concluded was "reworked deposits from an interstadial bog...preceding the last Wisconsin advance of the Okanogar lobe”. Nevertheless, some of the discounted TCN ages (Balbas et al., 2017, Table DR2) as v en 's unconformities within loess stratigraphy attributed to flood episodes also date to the mic lle Wisconsin (McDonald et al., 2012), keeping the question open.

- The youngest 12.9-12.5 ka age from radiocarbor-da ' $d$ offshore flood deposits reported by Zuffa et al. (2000, p. 258) is younger thar te rer rial ages showing that all Missoula floods preceded the 13.7-13.5 ka Glacier 'ea's tephra. The marine ages may be affected by uncertainties in marine ${ }^{14} \mathrm{C}$ reser oir corrections.

- Some of the OSL ages from tıf re gion are outside the ranges just summarized, most not by much (e.g. Smith et al. 201 $\iota^{\cdot}$ Hanson et al., 2012; Wells et al., 2020). OSL dating offers great potential for unders ' ndı $\mathrm{g}$ the floods, but discrepancies suggest more work is needed in understandin, th ar lication of OSL to the Missoula flood deposits.

- The average Ti ages for the maximum extent of the Okanogan lobe at $15.4 \pm 1.4 \mathrm{ka}$ and

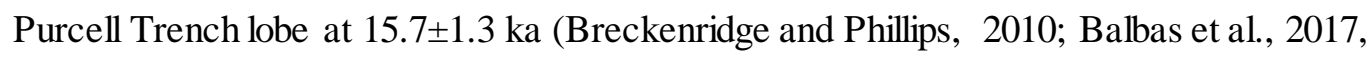
Table DR2) seem young relative to the radiocarbon-derived chronology. This is discrepancy is most evident relative to stratigraphic position of the $\sim 16 \mathrm{k}$ Set $\mathrm{S}$ tephra near the top of the glacial Lake Columbia section at Manila Creek (Hanson, 2013, p. 90, 116, 206), suggesting the demise of glacial Lake Columbia (and a Okanogan lobe terminus north of the Columbia valley) 300-500 yr after the tephra fall—about the same time as the TCN ages indicate ice 
pull-back from maximum positions. Post-deposition erosion of the TCN-dated surfaces or uncertain production rates could bias TCN ages to younger values. Another possibility is that the Set $\mathrm{S}$ tephra is younger than $16 \mathrm{ka}$, or possibly glacial Lake Columbia lasted longer than implied by the varve counts and tephra position in the Manila Creek section.

- Interbedded within Missoula flood rhythmites are at least four, and possibly five Mount St. Helens tephras (Mullineaux et al., 1978; Moody, 1978, p. 43-44; Moody, 1987, p. 43-44; Waitt, 1980, p. 664; Waitt, 1985, p. 1274-1275; Bjornstad etal., 1991, p. 231; Bunker, 1982; Baker and Bunker, 1985). These tephras include the promir ent Su-Sg couplet of the Swift Creek Stage eruptions of Mount St. Helens. This coupl t ot Set S ashes is a prominent

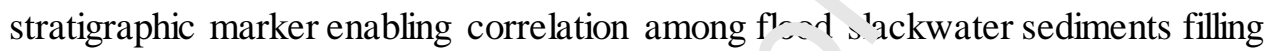
backflooded basins through much of eastern Wa $\mathrm{hH}_{\iota}{ }^{\text {ton }}$ and northeastern Oregon. It offers potential to improve counts of floods (e.g. (" of flood magnitude (e.g. Waitt, 19 5a. s. 1284; Benito and O'Connor, 2003) and the timing of various flood routes. Clynne et a' $(2008$, p. 619) summarize available age information and ambiguities for the Set $\mathrm{S}$, con $\mathrm{l}$ ldi ig it dates to $\sim 16 \mathrm{ka}$ but note discrepancies among reported ages of up to $\sim 500 \mathrm{yr}$ in bo: directions. A better age determination for this important and widespread stratigre nhic narker would refine Missoula flood timing. Finding traces of this tephra in section wit in the glacial Lake Missoula basin could enable more precise correlation of the lake history to flood and lake deposits along the flood route.

- Interflood intervals indicated by varve counts between flood deposits and evidence of lake level fluctuations, paleomagnetic secular variation, and the offshore record summarized by Gombiner et al. (2016) suggest periods of a one to two years up to 100+ yr between floods or lake releases. Most varve records show a general up-section count increase followed by a more prolonged overall decrease in counts. The decreasing trend implies progressively shorter lake-formation times, smaller volumes, and hence smaller floods in conjunction with a thinning Purcell Trench lobe ice dam (e.g. Atwater, 1986, p. 18, 22). In general, the maximum 
varve counts are 40-60 in glacial Lake Columbia (Atwater, 1986, p. 11), glacial Lake Spokane (Waitt, 1984, p. 53), and at the Ninemile section of glacial Lake Missoula (Figure 7b; Chambers, 1971, appendix III); although Kiver et al. (1991, p. 240) report as many as 125 varves between flood beds in the Latah Creek section likely formed in glacial Lake Spokane. The 40-60 yr maximum interval is slightly to substantially less than those implied by other records, including: (1) The duration and varve counts in the Mission Valley section of Lake Missoula deposits where Levish (1997, p. 97-108) infers 66 'ake cycles recorded by thickness variations in a sequence of $\sim 2670$ varves. Here, the averag $f,-l e$ is about 40 varves, but several have more than 60 and one has 107; (2) Paleor agn tic secular variation; Hanson (2013, p. 76-77, 114) suggests a best-match corre ${ }^{1+i_{1}}$ giving a 55-yr flood recurrence interval within the uppermost $\sim 46$ flood beds anr in ${ }^{\prime}$ rvening lacustrine deposits at the Manila Creek section, which is close to Atwater', rvf counts for the lower part of the section but double or triple his counts for the : npe part of the section measured by Hanson. Hanson (2013, p. 110) similarly determı 's a 55-80 yr refilling interval at the Rail Line section of glacial Lake Missoula; (3) Thi na ı ne record described by Cosma and Hendy (2008, p. 52) and Gombiner et al. (20 6,, 135$)$ shows a "stable" periodicity of $\sim 80 \mathrm{yr}$ separating the lowermost 22 flood bed deposited between 19.3 and $17.6 \mathrm{ka}$. Some of these discrepancies among the s``es nay jwe to erosion of varves by floods (e.g Atwater, 1986, p. 11; Hanson,

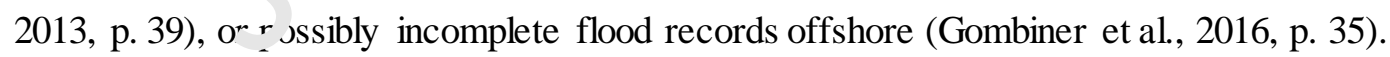

\section{How Many Floods?}

Bretz first focused on making the case for a single debacle. By his final papers, though, he counted seven or so from geomorphic relations, including pre-last-glacial floods (Bretzet al., 1956, p. 967, 10451048; Bretz, 1969, p. 527-530). Work in the 1970s by Baker (1973, p. 42; 1978b, p. 33-35) and Waitt (1977b) countered some of Bretz's evidence for multiple floods, whittling the number down to three or less last-glacial Missoula floods (Waitt, 1980, p. 653). 
These early interpretations, chiefly based on geomorphology, have been greatly augmented by stratigraphic analyses of flood and lacustrine deposits. Jerry Glenn's unpublished 1965 Willamette Valley dissertation and Waitt's (1980) analysis of the Burlingame Canyon section in the Walla Walla River valley (Figure 14) were the first to infer dozen of floods, about forty in each case, from tall exposures of layered slackwater deposits. Waitt's controversial finding (e.g. Bjornstad, 1980; Baker and Bunker, 1985; Waitt, 1985a; Smith, 1993; Clague 2003) was soon bolstered by the stratigraphy of glacial Lake Columbia (and possibly Spokane) showing dozens of flood beds separated by varves (Rigby, 1982; Kiver

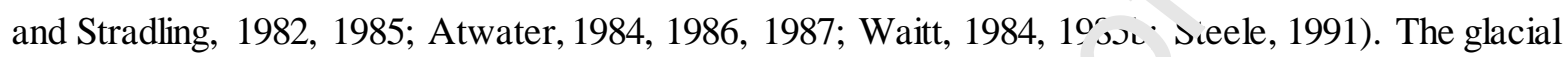
Lake Columbia sections studied by Atwater (1986) indicate 89 ser aral flood beds sequenced among 2,000-3,000 varves, including 15-17 post-dating the Mount s+ $\mathbf{H}^{\mathrm{l}} \mathrm{l}^{\mathrm{e}} \mathrm{ns}$ Set $\mathrm{S}$ tephra (Hanson, 2013, p. 90, 116). Other high counts include 62 beds counted by Bjornst? $d(980)$ in the Walla Walla valley near Touchet and the 44 beds in the marine core off Vanc ou $\mathrm{r}^{\text {' }}$ sland (Gombiner et al., 2016).

The position of Set S tephra within stratigra ' c sections allows us to add to the 89 flood beds counted at Manila Creek. In the backflooded Walla W. la valley, more than 28 rhythmites preceded the Mount St. Helens Set S tephra at Burlingame $\mathrm{Ca}, \mathrm{j}$, $($ Naitt, 1980, p. 659) and at least 31 rhythmites overlying the tephra were counted by Clague et a. (2013, p. 248) near Touchet, summing to at least 59 floods. Adding these 31 post-Set-S beds in the I ' s o Basin to the 72 preceding Set S at Manila Creek indicates at least 103 floods. Further addins the une or more floods down the Columbia before complete blockage by the Okanogan lobe means at least 104, possibly 109 floods if the four Moses Coulee floods are not recorded in the glacial Lake Columbia stratigraphy at Manila Creek. Most or all of these records are likely incomplete so the actual flood total is likely greater.

The multiple-flood record accords with the record of repeated emptying of glacial Lake Missoula. The most complete stratigraphic records, particularly the Ninemile (Figure 7b) and Rail Line sections west of Missoula show 40 lake cycles of slow filling followed by rapid emptying (Alt and Chambers, 1970; Chambers, 1971, 1984) and possibly as many as 80 (Hanson et al., 2012, p. 79). Levish (1997, p. 98-108, 
irregular pagination) describes 66 "packets" of thinning-up varve sequences in a Mission Valley section (Figure 1), but attributes these to surging glaciers modulating sediment supply rather than lake-level changes (p. 112-118). From varve counts, Atwater (1986, p. 22, 32; 1987, p.186) proposes a bed-to-bed correlation between the Manila Creek section of interbedded flood and lacustrine deposits and the Ninemile section recording filling and emptying cycles of glacial Lake Missoula.

\section{Flood Magnitudes and Routing}

How big were the Missoula floods? Thought huge from the very be ${ }^{-i n} \eta_{11}$, epithets such as "great vigor," "great flood," and "debacle" (Bretz, 1923a, p. 573, 588; 19.su, p. o49) instigated the early controversy regarding their possibility. But soon the estimates be ame quantitative and in recent decades more sophisticated. Nevertheless, the questions and controvers - continue, exemplified by the recent Perron and Venditti (2016) claim of "Megafloods dow «ze l." Also, how did flood sizes vary with timing and routings? These questions link flood size $t$, th $r$ evciution of the Channeled Scabland and its flood pathways as well as the history and dynami`s of glacial dams impounding glacial lakes Missoula, Columbia, and possibly Spokane. Missor la th d sizes have been studied by a variety of approaches, ranging from stratigraphic to compilla 'iona. So far, the evidence shows that the sizes of the scores of lastglacial Missoula floods ranged wia ly in in time and by place. Also emerging are more hypotheses, questions and conundrums, light. ng paths for future work.

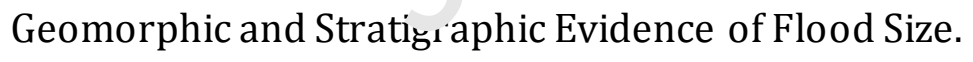

Relative flood size has been inferred by stratigraphic and geomorphic relations, such as from sequences of flood rhythmites inset into coarser flood bars (Benito and O’Connor, 2003, p. 636), upsection thinning and fining of individual floods deposits, and by the relative position of the Set-S tephra within rhythmite sequences at different elevations (Waitt, 1985a, p. 1284). Varve counts between flood beds also indicate relative flood magnitude by clocking lake growth between releases of glacial Lake Missoula. For example, the Manila Creek section in the Sanpoil valley shows general trends in the 
number of glacial Lake Columbia varves between flood beds (Atwater, 1986, p. 17, 22, 29). Here, the number of varves - probably marking years — ranges from 20 to 40 very low in the section, increases to a maximum of 45-55, and then gradual declines (with short reversals) to only one or two varves between the uppermost flood beds (p. 11, 22). The longer durations suggest bigger lakes and probably larger floods, also signaled by thicker flood beds (Atwater, 1986, p. 18, 22, 27). These stratigraphic and geomorphic approaches show that the Missoula floods perhaps first grew in volume but surely became smaller with time. The last few floods were likely much smaller, involvirg just a year or two's worth of accumulated water in glacial Lake Missoula, compared with 50-100, ca s $^{\circ}$ so indicated by the longest estimated flood intervals.

Pardee (1942, p. 1598) documented some of this disparitv in 4 ke release volumes and rates, noting that the coarse flood bars and giant current dunes emplarod by the "unusual currents" generated by at least one cataclysmic outflow (for example, Figure $? \cdot$ ) preceded shorelines etched as high as $1080 \mathrm{~m}$. Yet the preservation of shoreline features and associ ed flood features indicate that these later lakes must have drained more slowly or at least much les. vigorously. Deposits associated with these lower lake levels include "varved silt" along the ' inset into the higher coarser flood c nosıs (Smith, 2006; Hanson et al., 2012).

Continued mapping of $\mathrm{f}^{1} \mathrm{ou}$ landforms and deposits (e.g. Gordon et al., 2017; Hendrick et al., 2017; Doak et al., 2019), particula ${ }^{\top} y$ that based on growing lidar availability for the region (Gleason and Marker, 2019), will likely refine geomorphic and stratigraphic relations among flood sizes and routes. Such mapping in conjunction with detailed stratigraphy (e.g. Waitt, 1980; Atwater, 1986; Smith, 1993; Smith, 2017) and geochronology onshore and offshore (e.g. Balbas et al., 2017; Cosma et al., 2008) will provide solid ground supporting inferences drawn from computational flood analyses. 
Hydraulic Analyses

Starting with Bretz (1925b, p. 257-258), most quantitative estimates of flood discharge derive from hydraulic principles and models, relying on evidence of flood stage in conjunction with estimated channel geometry (Table 2). This approach was adopted in Baker's Ph.D. dissertation in which he employed hydraulic engineering approaches to flow calculation for estimating scabland flood conditions, including sediment transport and current dune formation (Baker, 1973). Other approaches contribute, including sediment-transport criteria, bedrock-erosion competence criteria, canyon- ormation constraints, and icedam erosion modeling. A main emphasis has been to estimate maximu. $\urcorner$ fl od discharge for the entire flow, hence efforts focused on: (1) reaches pertinent to maximun la $^{1 \text { re }}$ jischarge, including the ice dam itself (Clarke et al., 1984; Beget, 1986), the Rathdrum-Spok` ne $v$ lley just downstream from the ice dam (Baker, 1973; O’Connor and Baker, 1992; Denlinger ar.ì '’Connell, 2010), and Eddy Narrows in the Clark Fork Valley within the downstream arm of rla ial Lake Missoula (Pardee, 1942, p. 1596); and (2), downstream of Pasco basin where all flood route. converged at Wallula Gap (Bretz, 1925b, p. 257-258; Baker, 1973; Craig and Hanson, 1985, p. en-J?: O’Connor and Baker, 1992; Denlinger and O'Connell,

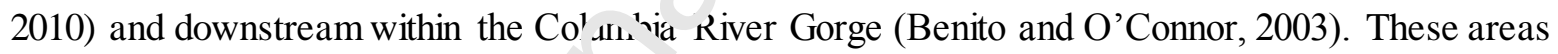
mostly avoid the complexities of thu multiple flood pathways of the Channeled Scabland.

Overall the general findi $\mathrm{g}$ t. $\mathrm{m}$ the hydraulic analyses is that emplacement of the maximum stage evidence indicates a peak dis sharge of about 20 million $\mathrm{m}^{3} / \mathrm{s}$ near the breached ice dam and about 5-15 million $\mathrm{m}^{3} / \mathrm{s}$ through Wallula Gap and downstream in the Columbia River Gorge (Table 2). A further constraint is that Eddy Narrows, the Clark Fork valley constriction in the downstream arm of glacial Lake Missoula (Pardee, 1942, p. 1572, 1594-1597), can at most pass about 30 million $\mathrm{m}^{3} / \mathrm{s}$ at critical flow associated with an energy head of $1295 \mathrm{~m}$ (maximum level of glacial Lake Missoula), thus giving an upper limit for the rate of sustained lake outflow. These values place the Missoula floods atop the list of known terrestrial outburst flood discharges (O’Connor et al., 2013). Wide ranges among these values in part reflect different boundary conditions, assumptions, and calculation approaches adopted by different 
efforts. Uncertainties also owe to the exceptionally energetic and dynamic flows and likely high sediment concentrations, but these are less understood (Carling et al., 2003). Much lower than these hydraulically based calculations are the theoretical and empirical estimates for the peak discharge associated with a subglacial release of the lake by thermal and mechanical erosion of the buoyed ice dam, which for boundary conditions like those of the hydraulic estimates, range from 2.1 to 3.5 million $\mathrm{m}^{3} / \mathrm{s}, 10-20 \%$ of the hydraulic estimates (Clarke et al., 1984; Beget, 1986; O’Connor and Baker, 1992, p. 277).

Discharges calculated for specific flood pathways are tentative and $\mathrm{w} \cdot \mathrm{e}$-ranging but include about 512 million $\mathrm{m}^{3} / \mathrm{s}$ for the Cheney-Palouse tract, 6 million $\mathrm{m}^{3} / \mathrm{s}$ for the Te 'foro Crab-Creek track, $0.1-13$ million $\mathrm{m}^{3} / \mathrm{s}$ for Grand Coulee, $0.6-11$ million $\mathrm{m}^{3} / \mathrm{s}$ for Moses $\mathrm{C} \sim \mathrm{u}^{\text {se, }}$, nd about 13 million for the Columbia valley sans Okanogan lobe near Wenatchee (Tabl 2). Some of the wide range is explicable by estimates that only account for portions of the flow within a pathway, such as those calculated by the canyon-formation modeling approach of a Lapotre $c$ al. ( 2016$)$. In addition, the large ranges for Grand Coulee and Moses Coulee owe to fundamentally istinct calculation approaches explained below. Clear, though, is that these values add together to gr atly exceed possible outflow from near the ice dam, showing the implausibility of any sing $\xi_{-}$fle $\_$emplacing the maximum flood evidence on all flood pathways.

The great range in disch rge esumates for individual flood routes is partly a result of the wide range of discharges (and volumes) or individual releases of glacial Lake Missoula. For example, a low 0.13 million $\mathrm{m}^{3} / \mathrm{s}$ estimate for Grand Coulee is based on the flow velocity required to transport sand of a flood bed within glacial Lake Columbia sediment mantling the floor of Grand Coulee (Atwater, 1987, p. 192). The lacustrine deposits enclosing this sand, however, are locally inset against a bouldery eddy bar built by more energetic floods down Grand Coulee. This eddy bar blocks the mouth of Northrup Canyon cataract complex, itself formed by floods of even higher stages that give the 13 million $\mathrm{m}^{3} / \mathrm{s}$ discharge estimated from one-dimensional flow modeling. Even though the 0.13 million $\mathrm{m}^{3} / \mathrm{s}$ likely underestimates the discharge associated with the flood bed enclosed within the glacial Lake Columbia deposits (Atwater, 
1987, p. 192), and the 13 million $\mathrm{m}^{3} / \mathrm{s}$ value from maximum flood evidence and present topography likely overstates the actual maximum discharge because of subsequent coulee enlargement, the 100-fold variation indicates the potential range of discharges and volumes of individual floods from glacial Lake Missoula. Such variation is broadly consistent with the varve-count ranges between flood beds in both glacial Lake Columbia and glacial Lake Missoula, implying varying durations and thus volumes of Lake Missoula between releases (Atwater, 1986, p. 22).

The possibility of wide-ranging flood discharge magnitudes was spe : ically addressed in the Columbia River Gorge (Benito and O’Connor, 2003). Here, step-back vate · flow modeling in conjunction with stratigraphic studies, geomorphic relations, and field evider $z$ of $r$ laximum flood stages, shows that at least one flow attained 10 million $\mathrm{m}^{3} / \mathrm{s}$, six or more exceer ed 5 million $\mathrm{m}^{3} / \mathrm{s}, 15$ were greater than 3 million $\mathrm{m}^{3} / \mathrm{s}$, and at least ten had discharges greater than 1 inillion $\mathrm{m}^{3} / \mathrm{s}$ but less than 3 million $\mathrm{m}^{3} / \mathrm{s}(\mathrm{p}$. 634).

\section{Two-Dimensional Hydrodynamic Flow Moci ling}

Two-dimensional, hydrodynamic flow no lels are now a tractable approach for quantifying Missoula flood flows. Inspired by questions i ivo 'ing multiple flow routes and flood dynamics and enabled by digital topography and improve $d$ co aputer processing power and software, such models are simulating flow at scales ranging $f_{1} \vee m$ ndiv dual flow tracts (e.g. Larsen and Lamb, 2016) to much of the terrestrial flood domain, including lin ${ }^{1}$ rs Missoula (Baker et al., 2016, p. 15-17; Liu and Baker, 2018; Denlinger et al., in press). Even off-shore modeling for the Willapa Bay submarine canyon under the eastern Pacific Ocean has supported understanding of possible routes of Missoula flood turbidity currents (Beeson, et al., 2017, p. 1724-1726). This recent work follows earlier two-dimensional applications by Craig (1987), Komatsu et al. (2000), Miyamoto et al. (2006, 2007), Alho et al. (2010) and Denlinger and O'Connell (2010). The advantage of two-dimensional flood modeling over previous one-dimensional calculations is that it enables evaluation of multiple, interacting flow routes and provides spatially explicit estimates of flow properties such as direction, velocity, shear stress and stream power. The dynamic capability of such 
models also gives information on the temporal variation of flow through the channel system as well as changes at specific locations.

Recent system-wide Missoula flood modeling gives insights on the overall evolution of the Channeled Scabland. The Denlinger et al. (in press) calculations employing the GeoClaw flow model (Berger et al., 2011) investigate several plausible Missoula-flood scenarios (Figure 15Error! Refe re nce source not found.). All model runs encompass the entire flood system, glacial Lake Missoula to the Pacific Ocean. All are based on overall end-member maximum-flood conditions of a $\mathrm{m}_{\mathrm{c}}$ · imum 1295-m glacial Lake Missoula draining from instant removal of the impounding Purcell Trı nch :e dam. The various runs

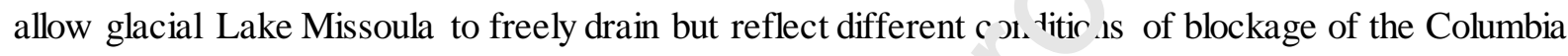
valley and Moses Coulee by the Okanogan lobe, as well as h ock d and unblocked states for upper Grand Coulee.

Figure 15. Stage predictions from hydrodynamic mod “n, re. 'lts of Denlinger et al. (in press) employing GeoClaw model (Berger et al., 2011). All model runs fully couple drainage ‘ "glacial Lake Missoula from its maximum 1295-m level and downstream flooding due to instantaneous and complen ice-dam removal. Model topography derived from $30 \mathrm{~m}$ digital elevation model adjusted for ice-margin positions derived fror $\mathrm{L}$, aitt and Thorson (1983), reservoir inundation, and Holocene fill of the Columbia River valley below Columbia Riv ?r :'ile Kiver 190 [after Baker et al. (2010) downstream of River Mile 120 and supplemented by drillers logs]. Model ca: 'ula. ons implement twenty-minute model time steps. Ice-rafted erratics mark approximate maximum stages at $d_{P}:{ }^{+} e a \cdot$ cations (Table 3). Three basic scenarios are modeled for each location: (1) Columbia Valley open to Missoula floods , "ior ... blockage by the Okanogan ice lobe, as shown in Figure 6Error! Reference source not found.b; (2) Columbia Valley by Llocked by Okanogan lobe but entrance to Moses Coulee open (Figure 6Error! Reference source not found.c); and (3) Okanogan lobe blocking Columbia Valley and entrance to Moses Coulee (Figure 6Error! Reference source not found.d). For each of these three situations, model trials assume that the Grand Coulee threshold is either at the modern 470-m elevation or at a higher, unincised or ice-blocked $680 \mathrm{~m}$, a plausible estimate of the pre-incision elevation of the coulee entrance (Waitt, in press). (a) Spokane Valley near Spokane (47.6890, -117.1090), about $75 \mathrm{~km}$ downstream from ice dam. Maximum inundation is for Missoula flooding coincident with a high-level 680-m glacial Lake Columbia. (b) Columbia River at the head of Grand Coulee (47.9406, -118.9483). Highest stages attained when Columbia River valley downstream is blocked by the Okanogan lobe. No results shown for maximum Okanogan lobe ice extent (Figure 6Error! Reference source not found.d) blocking Columbia Valley, Moses Coulee, and Grand Coulee because site is within presumed ice margin, but this 
scenario would produce highest local flood stages as indicated by Spokane-area results shown in part a. The two runs for the Columbia-River-open scenario produce the lowest local flood stages but also show the influence of a fully incised upper Grand Coulee diverting substantial flow, enough to reduce local maximum stage by nearly $40 \mathrm{~m}$. (c) Columbia River near Wenatchee (47.4526, -120.3167). Highest flood stages result from unblocked Columbia Valley scenarios, allowing down-Columbia passage of Missoula floods. A Grand Coulee outlet elevation of $470 \mathrm{~m}$ diverts enough flow to reduce stages in the Wenatchee area by 27 m. Yet even when Grand Coulee diverts no water, maximum calculated stages fall 20-30 m short of the highest local ice-rafted erratics. The low, 470-m Grand Coulee threshold also markedly reduces Moses Coulee flooding, thereby eliminating backflooding to Wenatchee area, compared to stages $40 \mathrm{~m}$ higher when Moses Coulee entrance is open, but the Grand Coulee divide is high at 680 m. (d) Columbia River in Pasco Basin (46.1937, -119.0414). Maxim ^." and most rapid inundation of Pasco Basin predicted for Missoula floods into high-level glacial Lake Columbia. Highest $m$, dele floods levels of $338 \mathrm{~m}$ fall short of local field evidence of maximum stages by 20-25 m. (e) Columbia River near Po tland 45.6498, -122.756). Similar to Pasco Basin, highest and most rapid flooding associated with high-level glacial L L lo l lumbia. Maximum predicted flood stages of $112 \mathrm{~m}$ about $10 \mathrm{~m}$ lower than highest nearby erratics.

All scenarios show floodwater escaping out of the $S_{1}$ 'k ne and Columbia River valleys into the Cheney-Palouse tract (Denlinger et al., in pre ' ). ' ne Telford-Crab-Creek scabland tract is only substantially flooded if glacial Lake Columı $\because$ is at a high level, here specified at $\sim 680 \mathrm{~m}$, requiring upper Grand Coulee either not yet incised to its c arr ent 470-m bottom elevation, or filled and blocked by ice of the Okanogan lobe. Likewise, Mosı s L vulee is flooded only when the Okanogan lobe blocks the Columbia valley, but not so fa: advi aced to block floodwater into the coulee (Figure 6Error! Reference source not found.c). A ${ }^{1}$ dit. nnal $y$, as postulated by Hanson (1970, p. 64, 79), if Grand Coulee is open, it diverts enough water such th at Columbia valley stages are lowered by about $40 \mathrm{~m}$ and Moses Coulee is hard to flood, implying that large Moses Coulee floods preceded final cataract retreat and lowering of the entrance to upper Grand Coulee. Similarly, modeled stages for the flood or floods down the Columbia valley sans Okanogan lobe (Figure 6Error! Reference source not found.b) more closely approach stages indicated by the highest ice-rafted erratics near Wenatchee (Figure 6Error! Refe rence source not found.Error! Reference source not found.c; Figure 8) if upper Grand Coulee is not yet fully cut. Problematically, no model trials yet produce flood stages high enough to match field evidence for 
maximum stages near Wenatchee, Pasco Basin, and the Portland Basin — the "volume problem" described below.

As for the simpler and earlier hydraulic assessments, these hydrodynamic models are hindered by uncertainties in boundary conditions (such as channel geometry at the time of the flow, positions of ice margins, and initial input flows); as well as hydraulic parameters such as boundary and internal friction losses, and sediment concentration - all poorly understood for flows so much larger than typically assessed with hydraulic models. Future modeling efforts will almost dou' 'less explore such uncertainties, but ultimately, flow modeling will continue to address various field-te tabls scenarios to resolve outstanding geologic questions such as progressive erosion and def sit' $\mathrm{n}$, effects of ice-lobe and glaciallake positions, effects of isostatic deformation, and possible vate" sources and sinks.

\section{The Volume Problem}

A persistent and perplexing result from the hyr odynamic modeling so far is that in all but the northern reaches it fails to produce flood sta es as high as field evidence for maximum flood stages (Baker, 2009, p. 406). This finding is most ev dent for the Pasco Basin (Figure 15; Komatsu et al, 2000; Miyamoto et al., 2007; Denlinger a Id ¿’Connell, 2010; Liu and Baker, 2018; Denlinger et al., in press).The modeling scenario that $\mathrm{c}$, mes closest is that for an advanced Okanogan ice lobe blocking the Columbia valley and the en. "anc 2 to Moses Coulee in combination with upper Grand Coulee blocked with ice or rock. For these conc ${ }^{: *}$.Jns, the maximum calculated stage in Pasco Basin is about $338 \mathrm{~m}$, still 20$30 \mathrm{~m}$ short of the maximum-stage field evidence of 360-366 m. Other plausible ice margin and channelevolution scenarios produce maximum model stages in Pasco Basin of 327-334 m. A Pasco Basin stage of $338 \mathrm{~m}$ implies a volume of $1065 \mathrm{~km}^{3}, 80 \%$ of the $1330 \mathrm{~km}^{3}$ volume required by a $360-\mathrm{m}$ ponding level (Table 1), an instantaneous volume shortfall of $\sim 265 \mathrm{~km}^{3}$.

Possible explanations for the volume shortfall? It is unlikely that uncertainties and approximations in modeling parameters and conditions, such as boundary and internal friction and grid resolution, could 
account for all the discrepancy (Miyamoto et al., 2007), but these possibilities should be investigated further. Perhaps Wallula Gap or narrows in the Columbia River Gorge downstream incised or widened during the floods such that first hydraulic ponding was higher and early floods left higher evidence. Yet the geologic evidence of pre-flood valley bottoms close to modern for Wallula Gap (Bretz, 1969, p. 535) and the Columbia River Gorge (O’Connor and Baker, 1992, p. 270) limits this explanation.

Flow bulking by entrained loess and valley-bottom sediment possibly increased flow volume. As noted above, the volume of offshore deposits associated with the thickes. Iood deposit implies a flood sediment concentration of $\sim 15 \%$ by volume. Flow bulking would be $n$ ost $]$ ronounced for the first flood(s) through the Cheney-Palouse and Telford-Crab-Creek sc at'and cracts, for which loess erosion would be greatest. Here, the tops of remnant loess islands co nme ly stand 50-100 m above scabland basalt channels, enabling a crude estimate of $\sim 200 \mathrm{~km}^{3}$ f $\sim$ ine total volume of eroded loess from the Channeled Scabland upstream of Pasco Basin. This 'tal auditional flood volume is likely insufficient to account for the $>250 \mathrm{~km}^{3}$ instantaneous volume lortfall in Pasco Basin indicated by the flow modeling at peak stage, particularly since the $\sim 50 \%$ porosı.: of the in-place loess reduces its effective flow-volume

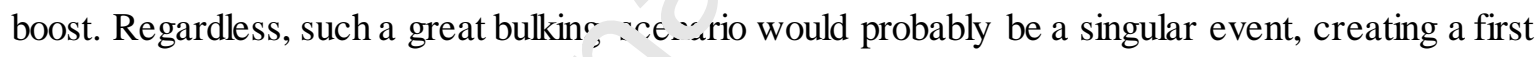
scabland flood substantially more c. gorged with sediment than subsequent floods coursing across an already eroded landscape. More : $v^{\epsilon}$ stigation of this possibility is nevertheless justified, including better offshore sediment volume ${ }^{-s i m a t e s}$ and perhaps provenance analyses to determine source areas.

Another possibility is multiple or different flood-water sources. This has been posed before, starting with Bretz's search for subglacial volcanism in British Columbia (Bretz, 1927b, p. 107). More recently, Shaw et al. (1999, p. 607-608) and Lesemann and Brennand (2009, p. 2436) proposed that "ice-sheet underbursts" in the Okanogan valley augmented Missoula flood flow, possibly accounting for the missing volume. Or perhaps a different and larger source independently sent a flood down the Columbia valley. The early flood down the Columbia sans Okanogan lobe is a candidate for an exceptionally large nonMissoula flood, but no such evidence for either a source or path has yet been described. Another plausible 
augmenting water source is glacial Lake Columbia or glacial Lake Spokane. An incoming Missoula flood compromising either impounding ice lobe could instigate a tandem release adding to glacial Lake Missoula flooding by the volume of the downstream ice-dammed lake-a possibility proposed by Atwater (1987, p. 199). Rip-up clasts of bedded sand and silt within the bouldery gravel under Okanogan lobe till in the Columbia valley led Hibbert (1985, p. 107) to hypothesize that an early flood entrained lacustrine sediment impounded by an earlier ice advance into Columbia valley. Glacial Lake Spokane seems too small to make enough difference, containing just $50 \mathrm{~km}^{3}$ at a $500-\mathrm{m}$ stage. Glacial Lake Columbia was possibly large enough; at a high, 715-730-m level, it $\mathrm{w}^{\prime}$, un ' huld $\sim 400-500 \mathrm{~km}^{3}$ of water, perhaps enough to make up the Pasco Basin shortfall if released cr cacı, smically and added to a large Missoula flood. This scenario is plausible, if not likely, durin aly phases of glacial Lake Columbia before the Okanogan lobe completely filled the Columbia v? lle,

\section{An Early "Mother of all Floods"?}

Recognition of dozens of Missoula floc ds inspı、d Waitt's (1980) then-controversial idea of repeated jökulhlaups from a self-dumping glacial a „ M/lissoula. Bolstering the jökulhlaup case is an overall decline in flood size (inferred from a nosı thickness) and intervals between floods (from varve counts) with time (Waitt, 1984, 1985a; Aı 'aur, 1984, 1986, p. 29), consistent with repeated releases tunneling beneath a thinning Purcell ${ }^{7}$ ren $\mathrm{h}$ ice dam. However, O’Connor and Baker (1992; p. 277) and Benito and O’Connor (2003, p. 636-63' concluded from stratigraphy, elevations of maximum stage evidence, chronology, and flow modeling that the first Missoula flood (or floods) was perhaps "distinctly larger." O'Connor and Baker (1992, p. 277) suggested this larger flood - affably satirized by Waitt as the "mother of all floods" (personal communications to O'Connor, 1990-2020)—likely came down the Columbia valley before blockage by the Okanogan Ice lobe. Moreover, this inference prompted the hypothesis by O'Connor and Baker (1992, p. 277) that early rupture of the Purcell Trench Lobe ice dam was more cataclysmic and complete than a later self-dumping sub-glacial jökulhlaup mode of ice-dam failure. 
Was the early flood preceding the Okanogan lobe's blockage of the Columbia, or any flood, "distinctly larger" and perhaps the result of a more cataclysmic mode of dam failure? Could such a flood address the volume problem? These questions are unresolved. As noted above, Missoula floods had greatly varying discharges. Flood magnitude apparently decreased markedly toward the end of the last glacial episode of flooding. The varve counts among the $\sim 89$ floods entering glacial Lake Columbia show an overall trend of a first increasing but then mostly diminished time interval between floods, consistent with floods getting larger than smaller as the damming Purcell Trench lcbe thickens and thins, impounding a correspondingly varying glacial Lake Missoula (Atwate . _`^4, 1986, p. 11, 29). The latter part of the glacial Lake Columbia record matches that of rhythmite sec ions along the flood route, which generally show up-section thinning of individual flood layers ' Fle. n, 1965; Waitt, 1980, 1985a; O'Connor et al., 2001) and is consistent with geomorphic re'atı 's in the Columbia River Gorge showing younger and smaller floods post-dating earlier larger on s ( 3enito and O’Connor, 2003).

Nevertheless it is evident that at least one e ${ }^{1}{ }^{1 /}$ and very large last glacial flood came down the Columbia River valley undiverted by the Oka'ngan lobe, depositing the immense Pangborn and Brays Landing bars (Figure 13) and emplaci sol el ics and eddy bars 250-320 m above modern river level for which preliminary hydraulic mode ' indicates a peak discharge of 10-13 million $\mathrm{m}^{3} / \mathrm{s}$ (Table 2). Also possible is that this was a multi-s ur zed flood combining volumes of glacial Lake Missoula and lakes Spokane and/or Columbia. I $C$, dating tentatively correlates (by timing) three high-level ice-rafted erratics from this flood (or tloods) near Wenatchee at $18.2 \pm 1.5 \mathrm{ka}$ to a high erratic close to maximum flood stage at Wallula Gap dated at 18.2 $\pm 1.6 \mathrm{ka}$ (Balbas et al., 2017). This flood (or floods) preceded those recorded in glacial Lake Columbia. It may be the flood that left the basal, 57-m thick flood deposit in the eastern Pacific (Zuffa et al., 2000; Normark and Reid, 2003).

As noted previously from geomorphic relations, Pardee (1942, p. 1598) inferred that initial drainage from glacial Lake Missoula was catastrophic, followed by filling and less vigorous emptying recorded in the low lacustrine deposits showing multiple lake-refilling episodes; a conclusion supported by 
stratigraphy and mapping by Smith (2006), geochronology (Smith et al., 2018) and hydraulic modeling by Alho et al. (2010). Yet Smith (2017) also showed that glacial Lake Missoula filled seven to 12 times to levels containing at least $65 \%$ of its maximum volume; and Benito and O’Connor (2003, p. 636) concluded from stratigraphy and modeling that at least six floods had discharges at least $65 \%$ of the maximum flow through the Columbia River Gorge. If a singular initial flood was largest, it was not larger by more than $\sim 50 \%$ as measured by peak discharge than later floods.

Hydraulic modeling of flow exiting glacial Lake Missoula (Denlinge $e^{\prime} t$ al., in press) and modeling of glacial Lake Missoula jökulhlaups by Clarke et al. (1984) address the ssue relative to the mode of icedam failure. Clarke et al.'s (1984) modeling, considering a varie $y$ - $f$ ic -dam geometries and parameters, predicted a plausible range of maximum discharge values of $2.6-15.3$ million $\mathrm{m}^{3} / \mathrm{s}$ for subglacial jökulhlaup-style releases at the ice dam. Beget (1986), fran an enıpirical analysis of historical jökulhlaups, suggested the lower value more likelv. These values are mostly lower than the minimum estimate of 14-20 million $\mathrm{m}^{3} / \mathrm{s}$ based on high-w. er evidence for flow through the Spokane-Rathdrum valley reach just downstream from the ice daı`(Table 2; O'Connor and Baker, 1992). Clarke et al. (1984, p. 294) described the possibility of $\mathrm{ca}^{+}{ }{ }^{+} \mathrm{rc}_{1}^{-1}$ - ic ice-dam failure caused by thermal erosion of the outflow tunnel to an extent that the "tunnel. of collapses during the flood and the dam is swept away," a possibility affirmed by calculatı $\urcorner$ s or maximum lake conditions by Waitt (1985a, p. 1282).

Ice dams release floods $\mathrm{L}$ th subglacially and by catastrophic failure (Walder and Costa, 1996; O'Connor et al., 2013, p. 481-483). It is possible that both types of ice-dam failure affected the Channeled Scabland; one or more large early release(s) by complete and rapid dam failure initiated either by tunneling or overtopping in conjunction with the maximum stand of glacial Lake Missoula, followed by a hundred or more smaller subglacial jökulhlaup releases in which the ice dam was not entirely removed. The distinction might be recognizable by a question not yet addressed — can the sedimentology of the flood deposits aid in distinguishing the distinctive types of hydrographs produced by different dam- 
failure modes (e.g. Clarke et al., 1984, p. 294; O’Connor and Baker, 1992, p. 276)? Until more such work is completed, the "mother of all floods" scenario remains hypothetical.

\section{Megafloods Downsized?}

A conclusion in the opposite direction in terms of flow size is proposed by Larsen and Lamb (2016). They apply a threshold bedrock-erosion model to estimate peak discharges for Missoula floods within Moses Coulee (Figure 12), leading to "much lower flood discharges than previously thought." Hence, the "Megafloods downsized" leader in Nature's accompanying News and View by Perron and Venditti (2016). Although their overall approach for modeling progressively _au. canyons is a valid new direction for flood research, their "downsizing" of previous Miss ula tlood discharge estimates relies on incomplete comparisons and assumptions.

Citing earlier estimates of Missoula flood dischar ; $\mathrm{e}_{\text {. }}$ e j. Baker, 1973; O’Connor and Baker, 1992; Denlinger and O'Connell, 2010), Larsen and ' am', (2016, p. 229) state "most hydraulic modelling efforts [in bedrock canyons] implicitly assume that 'he canyons were filled with water to their brims." This statement, which follows from Lapotre eı : 1. ( 2016 , p. 1232), misrepresents most Missoula flood calculations. Past Missoula flood ( $:$ nd 2 onneville flood) modeling in key locations, such as SpokaneRathdrum Valleys, Wallula Gå an i the Columbia River Gorge, does not rely on assuming a brim-full valley or canyon stage $L$ it i bas zd on field evidence of maximum-flow stages such as erosional trim lines, divide crossings anc ir e-rafted debris (Table 2; Baker, 1973; O’Connor and Baker, 1992; O’Connor, 1993; Benito and O’Connor, 2003). Only for Wallula Gap do these stages approximately coincide with a canyon "brim". Their point, though, addresses the critical assumption for all retrodictive palaeohydraulic modeling - that the modeled channel geometry approximates that extant during emplacement of the highest high-water evidence (e.g. Carling et al., 2003). This assumption indeed leads to overestimates of peak discharge if the valley deepened or widened since maximum flood levels. Alternatively, underestimates result if the valley has filled, as possibly the case for Rathdrum Valley (O’Connor and Baker, 1992, p. 274-276). Despite this limitation, previous flow modeling in the 
Channeled Scabland has used the modern topography to represent the flow geometry at the time of maximum flow stages. An essential fact not acknowledged by Larsen and Lamb, however, is that for the key estimates of peak discharges, particularly for Wallula Gap and the Columbia River Gorge, strong geologic evidence shows that the modern valley geometry is indeed appropriate for estimating flow (e.g. Bretz, 1969, p. 535; O'Connor and Baker, 1992, p. 270, 274-275). These earlier estimates purposefully were made in valleys that attained nearly all their present depths and widths before the Missoula floods.

In further comparing their threshold bedrock-erosion approach to the rrim-full” model, Larsen and Lamb (2016, p. 229) suggest that brim-full estimates for Channeled Sc bla d canyons imply a series of floods of increasing size "to maintain brim-full flow while the ce ny " n'oor erodes." They describe this scenario as unlikely and inconsistent with the proposed lake failu e mechanisms. This assertion is true, but such a scenario has never to our knowledge been pr vp sed, for it is inconsistent with the field evidence throughout the region. Nor has it been 근 ${ }^{1}$ ed for the Channeled Scabland. Indeed, the opposite has been demonstrated. Hydraulic and s. "atigraphic evidence throughout the area affected by Missoula floods shows that most earlier ftr - vds vere larger than later floods (e.g. Waitt, 1985; Benito and O’Connor, 2003).

Mechanistic approaches are cerı inly a valid direction for increasing knowledge of the Channeled Scabland and other floo ${ }^{-}$-fo mec landscapes. Threshold bedrock-erosion and canyon-formation models like that applied by Larsen a ıd Lamb (2016) and Lapotre et al. (2016) are promising approaches for investigating scabland channel erosion in erosional tracts such as Moses Coulee. Nevertheless, Larsen and Lamb's extension of the Moses Coulee analysis and conclusions to earlier estimates of megaflood peak discharges incompletely considers geologic context and key aspects of earlier work. 


\section{Columbia Basin Megafloods-Other Considerations}

Although the marks of the Missoula and Bonneville floods are most visible, other topics and questions continue to be relevant for understanding ice age floods of the Columbia River basin.

\section{Other Last-Glacial Floods}

Several other late Pleistocene floods besides the Missoula and Bonneville floods affected the Columbia River basin within both the Columbia and Snake River systems. Many of the known floods could benefit from more study. Many floods almost certainly have vatんん possibility of large, subglacial "ice-sheet underbursts" from unc' $r$ the nain Cordilleran ice lobes (Lesemann and Brennand, 2009, p. 2436).

Huge bars in the Columbia valley between the Metl $\sim$ w l iver confluence and Pasco Basin attest to at least one large down-Columbia flood after the may mum advance of the Okanogan ice lobe. These bars crest as high as $80 \mathrm{~m}$ above the Columbia $\mathrm{i}$ iver, are armored with car-size boulders, and are locally mantled by giant current dunes (Figure 1;, $\mathrm{Fi}$, ure 16Error! Reference source not found.). The bars appear to post-date the last Missoul . 1. nd. Bretzet al. (1956, p. 993-994) described one of these bars, Beverly Bar, a boulder-studded mo nd of gravel blocking the Crab Creek's coulee entrance to the Columbia valley (Figurs 5). In th is position Beverly Bar would be unlikely to survive substantial flow through Grand Coulee, flew hat would then rejoin the Columbia via lower Crab Creek. This relation prompted Bretzet al.'s (1956, p. 994) hypothesis that Beverly Bar, as well as the similar-sized West Bar upstream, owed to "break-up of the Okanogan lobe dam" and rapid emptying of glacial Lake Columbia, an idea posed by earlier Waters (1933, p. 817). Bretz later (1969, p. 525), however, attributed the Beverly Bar flood to Missoula flooding during a temporary pull-back of the Okanogan lobe. Geologic mapping by Waitt (1987, 2016) strengthened Bretz's initial hypothesis, aided by Atwater's (1987, p. 185-187) evidence that glacial Lake Missoula's final flood was at least 200-400 yr before the demise of glacial Lake Columbia. 
Figure 16. Deposits left by last-glacial, probably post-Missoula, outburst flood in the Columbia valley which we infer derived from cataclysmic emptying of ice-dammed Lake Columbia. (a) Rounded bar of bouldery gravel downstream of Methow River confluence with Columbia near River Mile 523, 15 km downstream from ice-dam blockage area at the Okanogan River confluence. Terrestrial cosmogenic nuclide analyses of three bouldersat this site give results of $13.0 \pm 1.1 \mathrm{ka}, 13.9 \pm 1.1 \mathrm{ka}$, and $15.3 \pm 1.3 \mathrm{ka}$ (Balbas et al., 2017, Table DR2). Scatter among individual boulder ages possibly owes to variable transport and exposure histories of measured boulders perhaps moved by earlier floods or by the overriding Okanogan ice lobe. Photograph by Jim E. O'Connor. (b) Upstream directed aerial view by Bruce Bjornstad of rippled West Bar from near Columbia River Mile 440, inferred deposited by an outburst of glacial Lake Columbia. Bar surface stands 60 m above Columbia River pool level. Inset into West Bar is another flood bar, possibly left by an outburst from glacial Lake Kooten., (Waitt, 2016).

Conditions were ripe for such a flood after the last Missoula flor $i$ ' hu while the Okanogan lobe was still blocking the Columbia River valley at the Okanogan River ` nnfluence. The resulting glacial Lake Columbia and the inflowing Columbia River exited through $\mathcal{L}$ ar $\mathbb{J}$ Coulee over the modern coulee floor threshold of $470 \mathrm{~m}$. Because of its outlet, the Okanoga 1 i ,e lobe dam and the impounded glacial lake were stable, with a lake surface $\sim 240 \mathrm{~m}$ above ne noa in Columbia River at the Okanogan River confluence. Ice-dam stability diminished $2 \varsigma$ it thinı d, probably reaching a critical thickness enabling subglacial tunneling and perhaps failure if $1 \omega^{-i c e}$ dam. Glacial Lake Columbia at this level relative to modern topography would contain ai vut $5: \mathrm{km}^{3}$ of water (Table 1), although this value likely overestimates the impounded wat - vciume because of substantial Holocene incision of upstream valley fill within the lake area. Ne verı eless, a glacial Lake Columbia outburst is a logical source for coarse deposits traced down the $\mathrm{Co}$ Imbia valley because no such deposits are evident above the Okanogan River confluence (Waitt, 2016, p. 434-436). No evidence has yet been found indicating multiple floods, so a singular rupture of the ice dam may have been the complete and final demise of glacial Lake Columbia.

Available chronology also indicates that glacial Lake Columbia is a plausible source. The demise of the lake post-dated the 16 ka Set S tephra and preceded the 13.7-13.4 ka Glacier Peak tephra. The downstream flood deposits also precede 13.7-13.4 ka (Waitt, 2016, 2017). TCN ages on of 11 boulders from five sites inferred deposited or remobilized by the post-Missoula flood range from $12.5 \pm 1.2$ to 
23.1 \pm 1.9 (Balbas et al, 2017, Table DR2). Discounting the single high outlier, the remaining ten ages average $14.4 \pm 0.3 \mathrm{ka}$.

Much more work can be done on this flood. Its deposits have neither been systematically mapped nor evaluated. More checking upstream could evaluate the possibility of other water sources, including a possibly reformed glacial Lake Missoula (Atwater, 1987, p. 199). No hydraulic calculations have yet estimated the peak flow of this flood, but abundant field evidence makes this a tractable undertaking. A tentative estimate made by applying Walder and Costa's (1996, p. 708) ^ ' vression for "non-tunnel drainage" floods from ice-dammed lakes (in contrast to sub-glacial tur nelin s releases) predicts a peak discharge of 0.13 million $\mathrm{m}^{3} / \mathrm{s}$ for a lake volume of $5.4 \cdot 10^{10} \mathrm{~m}^{3}$ a ss cia' ed with the final $470-\mathrm{m}$ Grand Coulee outlet elevation (Table 1, Table 2).

Another later flood followed the same Columbia va ler nath, leaving bouldery flood bars less than 35 $\mathrm{m}$ above the Columbia River (Figure 16b). The e, ars `re inset against the higher bars likely left by the emptying of glacial Lake Columbia and appear to ${ }_{1}$ 'st-date the 13.7-13.4 Glacier Peak eruption since its tephra has not been found on top of the b rs Searches for a source are still incomplete but a plausible candidate is glacial Lake Kootenay c' cup, ing the trough now partly filled with Kootenay Lake in southern British Columbia (Waitı, 2u:5, p. 436-437). Glacial Lake Kootenay grew in front of the Purcell Trench ice lobe as it recede $\lrcorner \mathrm{m}$ th, its way to the Columbia via the Kootenay River blocked by the lingering ice lobe. At its ma imum, the lake covered $1152 \mathrm{~km}^{2}$ with $142 \mathrm{~km}^{3}$ of water as much as $400 \mathrm{~m}$ deep. Once the retreating Purcell trench lobe uncovered the outlet valley leading west, the lake drained, possibly cataclysmically. Peters and Brennand (2020) map evidence of the lake and outburst flood in the Kootenay River valley which they attribute to this scenario, although they name the lake "glacial Lake Purcell'. Other ice-dammed lakes in the northern Columbia River basin also formed in deglaciated tributary valleys, blocked by lagging ice in the main valleys. Some, like $20 \mathrm{~km}^{3}$ Elk Lake, dammed by the remnant Purcell Trench lobe, also appear to have emptied rapidly, possibly with a discharge as great as $60,000 \mathrm{~m}^{3} / \mathrm{s}$ (Clague, 1975, p. 233-234). Evidence of these floods has yet to be traced downstream. 
Additional Pleistocene-age floods from both ice-dammed and pluvial lakes entered the Snake River system. Lamb et al. $(2008,2014)$ attribute amphitheater-headed canyons entering the Snake River within the Snake River Plain to outburst floods possibly about $45 \mathrm{ka}$. Candidate sources for these floods are alpine-glacier-dammed lakes in the central mountains of Idaho, such as in the basins in the Lost River headwaters (Rathburn, 1993; Cerling et al., 1994) and Big Wood River (Othberg et al., 2012, p. 4). A large flood from pluvial Lake Alvord in eastern Oregon entered the Owhyee River, tributary to the Snake River, sometime after the $\sim 16$ ka Set $S$ tephra fall. Like the Bonneville f'ood, but much smaller, Lake Alvord overtopped and eroded an unconsolidated divide, releasing abc $\lrcorner: 1.2 \mathrm{~km}^{3}$ of water at a peak flow of about 10,000 $\mathrm{m}^{3} / \mathrm{s}$ (Carter et al., 2006). A similar but smaller flc dd 1 sulted from the breaching of pluvial Lake Millican in central Oregon, sending $\sim 7 \mathrm{~km}^{3}$ of $w^{n+\infty}$ : nto the Deschutes and lower Columbia rivers, possibly in the middle Pleistocene (Vanaman et al., 290 ; Smaller Holocene outburst floods from landslide- and moraine-dammed lakes have also affe $t \mathrm{t}$, riv ers and streams of the Columbia River basin, summarized in O'Connor et al. (2013).

\section{Older flood episodes??}

Megaflood evidence of the last ire age is most prevalent and studied. However, deposits of earlier large floods in the Columbia valley near Wenatchee, in Quincy basin, the Cheney-Palouse scabland tract, in Pasco basin, and possibly the inake River Plain, show that megafloods have a long Quaternary history in the Columbia Basin, likely associated with earlier ice ages (Bretz et al. 1956; Richmond et al., 1965; Baker, 1973; Patton and Baker, 1978b; Baker et al., 1991; Bjornstad et al., 2001; Lamb et al., 2008, 2014; Medley, 2012).

The most compelling evidence of much older flooding is foreset-bedded gravel capped with thick loess sequences containing petrocalcic soil horizons (Figure 17Error! Refe rence source not found.). Such outcrops are found in the Cheney-Palouse scabland tract (Patton and Baker, 1978b; Bjornstad et al., 2001; Baker et al., 2016, p. 51-52), along the Columbia Valley near Wenatchee, where foreset-bedded 
gravel capped with a thick petrocalcic horizon lies upslope of the massive last-glacial Pangborn bar (Waitt, in press), and in the western Quincy basin, where two old floods left carbonate-cemented eastdipping foreset gravels derived from floods spilling out of the Columbia Valley south of Wenatchee (Bretzet al., 1956, p. 985; Bretz, 1969, p. 524; Baker, 1973, p. 8-9).

Figure 17. Thick sequences of loess and paleosols containing strongly formed calcic horizons, capping poorly sorted but stratified and locally foreset bedded basalt cobble gravel. Such deposits indicate flood episodes prior to the last glacial period. Photographs by Jim E. O'Connor. (a) Old Maid Coulee site (46.6045, -118.8599) where Bjornstad et al. (2001, p. 698) reported flood gravel capped by reversed-polarity soil and >350 ka calcic horizon. (b) Marengo har, ite within Cheney-Palouse scabland tract (47.0126, -118.2134), also reported by Bjornstad (2001, p. 698) as a flood grave. vve lain by reversely magnetized loess and an 800-ka calcic horizon. Hammer $40 \mathrm{~cm}$ long.

Pasco basin contains the most studied and diverse eviden ` fo floods throughout the Quaternary. This ranges from foreset-bedded boulder-gravel to rhythmit - li'.e sequences of bedded silt and clay, typically distinguished from last glacial flood deposits br $p_{\mathrm{r}}$ minent calcic horizons, which last glacial deposits lack (Bjornstad et al., 1991, p. 228-235; 2001, p. '77-711; Medley, 2012, p. 116-119). Some of the large last-glacial flood bars in Pasco Basin, sur it \& C c ld Creek bar, appear cored by older flood bars (Bjornstad et al., 2001, p. 707-709; Pluhar et al 204 $)$. Bjornstad et al. $(1991,2001)$ identify at least two episodes of pre-last-glacial flooding; a mic. "le ?leistocene episode sometime between $130 \mathrm{ka}$ and $780 \mathrm{ka}$, and an early Pleistocene episode of cer than $780 \mathrm{ka}$, preceding the Brunhes-Matuyama geomagnetic reversal. In the Walla Walla valley, Bac $r$ et al. (2016) identify two pre-last-glacial but post-220-ka diamicts bounding unconformities in a thick loess sequence. The diamicts contain extrabasinal clasts attributed to middle Pleistocene glacial-outburst floods.

Older flood episodes have also been inferred from the soil and loess stratigraphy flanking scabland channels (Busacca and McDonald, 1994; Gaylord et al., 2001; Sweeney et al., 2007; McDonald et al, 2012). Most evidence is indirect and derives from the extensive dune formation and loess deposition nourished by last-glacial flood deposits. Associated with last-glacial flooding is the prominent "L1 loess," which commonly contains the Mount St. Helens Set S tephra near its base, indicating active accumulation 
during Missoula flooding (McDonald and Busacca, 2012, p. 20). They similarly attribute the underlying L2 loess to possibly larger glacial Lake Missoula outburst floods crossing the Channeled Scabland and into Pasco Basin during oxygen isotope stage 4 between about 77 and 44 ka (p. 28), although equivalent age slackwater deposits have yet to be found (p. 24).

So far, evidence for older flooding is confined to the Cheney-Palouse scabland tract, the Columbia valley upstream of Pasco Basin (including that of floods spilling east into Quincy basin), and Pasco basin. Unresolved is if pre-last-glacial floods affected Moses Coulee or Grand Tulee. No older flood deposits have yet been found downstream of Pasco basin, possibly indicating $\mathrm{s}$ 'ch $\mathrm{t}$ jods were smaller than the largest of the Missoula floods.

Also unknown is what might have been the sources of ear 'ier oods affecting the Channeled Scabland. No evidence has yet been reported for pre-last-glacial er,inns of glacial Lake Missoula. Geologic mapping conducted in western Montana report $\omega_{1}{ }^{1} y_{k}{ }^{\text {te }}$ Pleistocene glaciolacustrine sediment, locally overlying flood gravels and bedforms (Berg, 200t, 2005, Lonn et al., 2010, 2007). Additional chronology of the flood gravel and deposits near the er rinal positions of the Pend Oreille lobe (Breckenridge et al., 1989; Smyers and Breckenridge, 200' ) cu ld resolve whether some of those deposits are older. By contrast, it is likely that there we e $^{-}$-lier versions of glacial Lake Columbia, judging from the pre-lastglacial incision and southw ia hilı of the Columbia River through the northernmost extent of the Columbia River Basalt Grou ) (Pardee, 1918, p. 46; Flint, 1935, p. 175-176; Hibbert 1985, p. 94), most plausibly by earlier glacial blockage of an earlier river route skirting the northern basalt margin.

\section{Witnesses?}

"Were there witnesses?" This common question is specifically addressed by Waitt (2016, p. 442). The question gained notice and was seemingly answered by a stone knife extracted by Luther Cressman in 1953 from a Missoula flood gravel deposit in the Columbia River Gorge (Cressman, 1960, p. 63-66; 1977, p. 50-51, 71). But recent reevaluation suggests that the knife is not actually a knife but rather a 
“fortuitously flood-bruised basalt pebble" Waitt (2016, p. 442). The knife discounted, no compelling physical evidence is yet reported for humans, their tools, or their habitations within or under ice-age megaflood deposits in the Pacific Northwest.

But the timing of last-glacial floods hints of possible megaflood viewing by early North American inhabitants. Davis et al. (2019) document human occupation of the Coopers Ferry site (Figure 5) in the Snake River basin by 16.56-15.28 ka (two-sigma uncertainty derived from Bayesian age model of 25 radiocarbon ages). This age post-dates the 18.3-18 ka Bonneville flood c.'vn the Snake River, but it very plausibly precedes the last of the Missoula floods, of which $\sim 30$ were c fter ihe $\sim 16$ ka Set S tephra fall. The site itself, at $\sim 420$ m elevation, was probably just out of rear $h_{1} \sim r_{.}$Missoula flood backflooding up the Snake River, where the highest Missoula floods left peb: v si s and ice-rafted erratics up to $\sim 395 \mathrm{~m}$ near Lewiston. It is even more likely that that humans $r, c, z$ in the region and possibly witnessed the lateglacial floods coming down the Columbia valler $-f \mathrm{tt}$ : the last of the Missoula floods.

\section{Columbia Basin Megafloods and "Wings of the Morning"}

The region is uniqu $\cdot \mathrm{t}^{*}$ the observer take wings of the morning to the uttermost priw oj the Earth: he will nowhere find its likeness

Bretz, 1928b, p. 446

The Columbia River basin is where megafloods controversially launched, led by J Harlen Bretz's outrageous hypothesis. Yet other megafloods scarred the region, such as the Bonneville flood spilling out of the Great Basin and down the Snake River, more quietly discovered earlier by G.K. Gilbert. Nearly 100 years from Bretz's first paper outlining and defining the Channeled Scabland, the spectacular flood landscapes of the Columbia River basin still inspire. The region is accessible, well-studied, of huge popular interest, and attracts new tools, techniques, and hypotheses — some outrageous. Hence, the unique 
landscape continues to breed controversy, motivating even more research into cataclysmic floods and flood processes.

Bretz's relentless advocacy for the singularity of the Channeled Scabland ultimately convinced the scientific community of a great-flood genesis. Yet if the "wings of the morning" had taken him higher in 1928, he would have seen that the region is not unique. Soaring only slightly higher, he would have seen a likeness in the scabland left by the Bonneville flood $\sim 600 \mathrm{~km}$ to the southeast, carved by the débâcle described the previous century by G.K. Gilbert. At an orbital level, looku down at the spinning Earth, he would see cataclysmic flood features across terrestrial and submarine ands :apes worldwide (e.g. Baker, 209, p. 405, 2013, 2020). Looking up with eagle eyes, he may he vo spr ted the flood channels scarring other planets (e.g. Baker, 1982; Burr et al.,2009). Yet much if th understanding of these far-flung flood landscapes can be ultimately traced to what was first seen on the ground by Bretz, Gilbert, Malde, and others in the megaflood terrain of the Columbia Riv basın.

\section{Acknowledgements}

Discussions and reviews by Bruce Biırns` `d, Brian Atwater, Juergen Herget, and Isaac Larsen have improved this report. Additionally, o or work has been aided by discussion, assistance, and support by countless colleagues over th $-y$ - 11 . We thank Paul Carling, guest editor for this special megaflood volume, for the invitation te sontribute and for editorial oversight.

\section{References Cited}

Abril-Hernández, J.M., Periáñez, R., O’Connor, J.E., Garcia-Castellanos, D., 2018. Computational Fluid Dynamics simulations of the Late Pleistocene Lake Bonneville Flood. J. Hydrol. 561, 1-15. https://doi.org/10.1016/J.JHYDROL.2018.03.065

Adams, K.D., Bills, B.G., 2016. Isostatic rebound and palinspastic restoration of the Bonneville and 
Provo shorelines in the Bonneville Basin, UT, NV, and ID. Dev. Earth Surf. Process, 145-164. https://doi.org/10.1016/B978-0-444-63590-7.00008-1

Amidon, W.H., Farley, K.A., 2011. Cosmogenic 3He dating of apatite, zircon and pyroxene from Bonneville flood erosional surfaces. Quatern. Geochronol. 6, 10-21. https:// doi.org/10.1016/j.quageo.2010.03.005

Archaeological Investigations Northwest, 2015. Archaeological Damage Assessment and Monitoring Summary for the Mill Creek North Mitigation Site for the SR 502 Cu. ridor Widening Project, Clark County, Washington. Report 3360 (for Washington State Depart ${ }_{1}$.n. of Transportation, Vancouver, Wash.).

Adams, K.D., Bills, B.G., 2016.Isostatic rebound and palinsras، “ restoration of the Bonneville and Provo shorelines in the Bonneville basin, UT, NV, and 1 . . ev. Earth Surf. Process. 20, 145-164. https://doi.org/10.1016/B978-0-444-6350 -1.' 000১-1

Alho, P., Baker, V.R., Smith, L.N., 2010. Paı hydraulic reconstruction of the largest Glacial Lake Missoula draining(s). Quat. Sci. N`v. or, 3067-3078. https://doi.org/10.1016/j.quası rev. 2010.07 .015

Allen, J.E., Burns, M., Burr , L , $\angle$ v09. Cataclysms on the Columbia : the great Missoula floods, 2nd ed. Ooligan Press.

Allison, I.S., 1978. Late Pleistocene sediments and floods in the Willamette Valley. The Ore Bin, 40, 177-191; 192-202.

Allison, I.S., 1941. Flint's Fill Hypothesis of Origin of Scabland. J. Geol. 49, 54-73. https://doi.org/10.1086/624944.

Allison, I.S., 1935. Glacial erratics in Willamette Valley. Bull. Geol. Soc. Am. 46, 615-632. https://doi.org/10.1130/GSAB-46-615 
Allison, I.S., 1933. New Version of the Spokane Flood. Bull. Geol. Soc. Am. 44, 675-722. https://doi.org/10.1130/GSAB-44-675

Alt, D., Chambers, R.L., 1970. Repetition of the Spokane flood [abs.], in: American Quaternary Association Meeting. Montana State University, Bozeman, 1.

Amidon, W.H., Clark, A.C., 2015. Interaction of outburst floods with basaltic aquifers on the Snake River Plain: Implications for Martian canyons. Bull. Geol. Soc. Am. 127, 688-701. https://doi.org/10.1130/B31141.1

Arnow, T., Stephens, D.W., 1990. Hydrologic characteristics of th : G 'at Salt Lake, Utah, 1847-1986. U.S. Geol. Sur. Water Supply Pap. 2332. https://doi.org/1n 3:33/wsp2332

Atwater, B.F., 1987. Status of glacial Lake Columbia dıring the wust floods from glacial Lake Missoula. Quat. Res. 27, 182-201. https://doi.org/10.1016 00د-5894(87)90076-7.

Atwater, B.F., 1986. Pleistocene Glacial-Lake Du, 'sits of the Sanpoil River Valley, Northeastern Washington. U.S. Geol. Surv. Bull. «'`1. ittps://doi.org/10.3133/b1661 .

Atwater, B.F., 1984. Periodic floods 1 . רm glacial Lake Missoula into the Sanpoil arm of glacial Lake Columbia, northeastern Wası ington. Geology 12, 464-467. https $/ /$ doi.org/10.1130/00917613(1984) $12<464 \cdot$ PF FGL $\Lambda>2.0 . \mathrm{CO} ; 2$

Atwater, B.F., Smith, G.A., and Waitt, R.B., 2000. The Channeled Scabland: back to Bretz? Comment. Geology 28, 574-575. https://doi.org/10.1130/0091-7613(2000)28<576:TCSBTB>2.0.CO;2

Bader, N.E., Spencer, P.K., Bailey, A.S., Gastineau, K.M., Tinkler, E.R., Pluhar, C.J., Bjornstad, B.N., 2016. A loess record of pre-Late Wisconsin glacial outburst flooding, Pleistocene paleoenvironment, and Irvingtonian fauna from the Rulo site, southeastern Washington, USA. Palaeogeog., Palaeoclim., Palaeoecol. 462, 57-69. https://doi.org/10.1016/j.palaeo.2016.08.042

Baker, D., Peterson, C., Hemphill-Haley, E., Twichell, D., 2010. Latest Pleistocene and Holocene (2- 
16ka) sedimentation in the Columbia River Estuary, Oregon, USA. Mar. Geol. 273, 83-95. https://doi.org/10.1016/j.margeo.2010.02.005

Baker, V.R., 2020. Global megaflood paleohydrology, in: Herget, J. and Fontana, A., (Eds.), Palaeohydrology. Geography of the Physical Environment: Springer, Heidelberg, 3-28. https://doi.org/10.1007/978-3-030-23315-0_1

Baker, V.R., 2013. Global Late Quaternary Fluvial Paleohydrology: With Special Emphasis on Paleofloods and Megafloods, in: Wohl, E.E. (Ed.), Treatise on Geom rohology. Elsevier, 511-527. https://doi.org/10.1016/B978-0-12-374739-6.00252-9

Baker, V.R., 2009. The Channeled Scabland: A Retrospective $A_{\iota_{1}} \cdot u$. Rev. Earth Planet. Sci. 37, 393411. https://doi.org/10.1146/annurev.earth.061008.13472七

Baker, V.R., 2008. The Spokane Flood debates: hist icai vackground and philosophical perspective, in: Grapes, R.H., Oldroyd, D., Grigelis, A. ( $\mathrm{L}^{`}$.), History of Geomorphology and Quaternary Geology. Geological Society, London, London. Si -50. https://doi.org/10.1144/SP301.3

Baker, V.R., 1998. Catastrophism an ( un. ormitarianism: logical roots and current relevance in geology, in: Blundell, D.J., and Scoti, A.` (Eds), Lyell: The past is the key to the present: Geological Society of London, Special Pv'sul tivil 143, 171-182. https:/doi.org/10.1144/GSL.SP.1998.143.01.15

Baker, V.R., 1995. Joseph T ımas Pardee and the Spokane Flood Controversy. GSA Today 5, 169-173.

Baker, V.R., 1982. The channels of Mars. University of Texas Press, Austin, Texas.

Baker, V. R. (Ed.). 1981. Catastrophic Flooding: The Origin of the Channeled Scabland. Dowden, Hutchinson \& Ross, Stroudsburg, PA.

Baker,V.R., 1978a. The Spokane Flood controversy and the Martian outflow channels. Science 202, 1249-1256. https://doi.org/10.1126/science.202.4374.1249 
Baker, V.R., 1978b. Quaternary geology of the Channeled Scabland and adjacent areas, in: Baker, V.R., Nummeddal, D. (Eds.), The Channeled Scabland. National Aeronautics and Space Administration Planetary Geology Program, Washington, D.C., 17-35.

Baker, V.R., 1973. Paleohydrology and Sedimentology of Lake Missoula Flooding in Eastern Washington, Geological Society of America Special Paper 144. Geological Society of America. https://doi.org/10.1130/SPE144-p1

Baker, V.R., Bjornstad, B.N., Busacca, A.J., Fecht, K.R., Kiver, E.P., Mua 'v, U.L., Rigby, J.G., Stradling, D.F., Tallman, A.M., 1991. Quaternary Geology of the C $^{\prime}$. mmbia Plateau, in: Morrison, R.G. (Ed.), Quaternary Nonglacial Geology. Geological Sc iety of America, Boulder, Colorado, 215-250. https://doi.org/10.1130/DNAG-GNA-K2.215

Baker, V.R., Bjornstad, B.N., Gaylord, D.R., Smith, J. ^.., ’ leyer, S.E., Alho, P., Breckenridge, R.M., Sweeney, M.R., Zreda, M., 2016. Pleistc enf megaflood landscapes of the Channeled Scabland, in: Exploring the Geology of the Inland I' rthwest, Geol. Soc. Am. Field Trip Guide 41, 1-73. https://doi.org/10.1130/2016.0041(C1)

Baker, V.R., Bunker, R.C., 1985. C эtacı/smic late Pleistocene flooding from glacial Lake Missoula: A review. Quat. Sci. Rev. 4, :-4 . https //doi.org/10.1016/0277-3791(85)90027-7

Baker, V.R., Milton, D.J., 1.74. Erosion by catastrophic floods on Mars and Earth. Icarus 23, $27-41$. https://doi.org/10.1016/0019-1035(74)90101-8

Balbas, A.M., Barth, A.M., Clark, P.U., Clark, J., Caffee, M., O’Connor, J., Baker, V.R., Konrad, K., Bjornstad, B., O’Connor, J., Baker, V.R., Konrad, K., Bjornstad, B., 2017. ${ }^{10}$ Be dating of late Pleistocene megafloods and Cordilleran Ice Sheet retreat in the northwestern United States. Geology 45, 583-586. https://doi.org/10.1130/G38956.1

Beeson, J.W., Goldfinger, C., and Fortin, W.F., 2017. Large-scale modification of submarine geomorphic 
features on the Cascadia accretionary wedge caused by catastrophic flooding events. Geosphere 13, 1713-1728. https://doi:10.1130/GES01388.1

Beget, J.E., 1986. Comment on "outburst floods from glacial Lake Missoula" by G. K. C. Clarke, W. H. Mathews, and R. T. Pack. Quat. Res. 25, 136-138. https://doi.org/10.1016/0033-5894(86)90050-5

Benito, G., 1997. Energy Expenditure and Geomorphic Work of the Cataclysmic Missoula Flooding in the Columbia River Gorge, USA. Earth Surf. Process. Landforms 22, 457-472. https://doi.org/10.1002/(SICI)1096-9837(199705)22:5<457::AID-Esı 762>3.0.CO;2-Y

Benito, G., O'Connor, J.E., 2003. Number and size of last-glacial I liss ula floods in the Columbia River valley between the Pasco Basin, Washington, and Portland Tregon Geol. Soc. Amer. Bull. 115, 624-638. https://doi.org/10.1130/0016-7606(2003)115\%3 万 1)624:NASOLM\%3E2.0.CO;2

Berg, R.B., 2006. Geologic map of the Upper Clark 'ork $v$ alley between Bearmouth and Missoula, southwestern Montana. Open-File Reporı : 5 . Montana Bureau of Mines and Geology, Butte.

Berg, R.B., 2005. Geologic map of the U P r C.ark Fork Valley between Garrison and Bearmouth, southwestern Montana, Open-File n p port 523. Montana Bureau of Mines and Geology, Butte.

Berger, M.J., George, D.L., LeVeq`• ${ }^{\circ}$, R.J., Mandli, K.T., 2011. The GeoClaw software for depth-

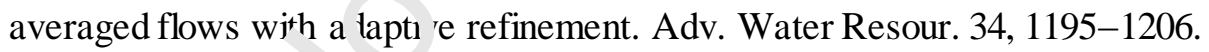
https://doi.org/10.1016/ .ADVWATRES.2011.02.016

Bjornstad, B.N., 2014. Ice-rafted erratics and bergmounds from Pleistocene outburst floods, Rattlesnake Mountain, Washington, USA. Quaternary Science Journal 63, 44-59. https://doi.org/10.3285/eg.63.1.03

Bjornstad, B.N., 1980. Sedimentology and depositional environment of the Touchet Beds, Walla Walla River Basin, Washington. Eastern Washington University.

Bjornstad, B.N., Fecht, K.R., Pluhar, C.J., 2001. Long History of Pre-Wisconsin, Ice Age Cataclysmic 
Floods: Evidence from Southeastern Washington State. J. Geol. 109, 695-713. https://doi.org/10.1086/323190

Bjornstad, B.N., Fecht, K.R., and Tallman, A. M., 1991, Quaternary stratigraphy of the Pasco Basin, south-central Washington; in Baker; V.R.; Bjornstad; B.N.; Busacca; A.J.; Fecht; K.R.; Kiver; E.P.; Moody; U.L.; Rigby; J.G.; Stradling; D.F.; and Tallman; A.M.; authors; Quaternary Geology of the Columbia Plateau; in Morrison; R.G.; ed.; Quaternary Nonglacial Geology; Conterminous U.S.: Boulder; Colorado; Geological Society of America; Geology of Nc +'n America; v. K-2; 238-250. https://doi.org/10.1130/DNAG-GNA-K2.

Bolke, E.L.V., Washington, J.J., 1980. Digital model simulation of tıc hydrologic flow system, with emphasis on ground water in Spokane Valley, Washing. n : nd Idaho, U.S. Geol. Surv. Open-File Report 80-1300. https://doi.org/10.3133/ofr80130 ,

Booth, D.B, 1986. Mass balance and sliding $\mathrm{v} \cdot \mathrm{loc}^{\mathrm{y}} \mathrm{y}$ of the Puget lobe of the Cordilleran ice sheet during the last glaciation. Quat. Res. 25, 265. 280. https://doi.org/10.1016/0033-5894(86)90001-3

Breckenridge, R.M., Atwater, B.F., B ${ }^{1-a r, ~ V . R ., ~ B u s a c c a, ~ A . J ., ~ C h a m b e r s, ~ R . L ., ~ C u r r y, ~ R . R ., ~ H a n s o n, ~}$ L.G., Kever, E.P., McDonala, E. V., Stradling, D.F., Waitt, R.B., 1989. Glacial Lake Missoula and the Channeled Scabland. 11. Ir ernational Geological Congress, 28th, Guidebook. American Geophysical Union, 'Na-lington D.C. https://doi.org/10.1029/FT310

Breckenridge, R.M., Othberg, K.L., 1998a. Surficial Geologic Map of the Post Falls Quadrangle and Part of the Liberty Lake Quadrangle, Kootenai County, Idaho. Idaho Geol. Surv. Surficial Geol. Maps SGM-5.

Breckenridge, R.M., Othberg, K.L., 1998b. Surficial Geologic Map of the Rathdrum Quadrangle and Part of the Newman Lake Quadrangle, Kootenai County, Idaho. Idaho Geol. Surv. Surficial Geol. Maps SGM-6. 
Breckenridge, R.M., and Phillips, W.M., 2010. New cosmogenic 10Be surface exposure ages for the Purcell Trench lobe of the Cordilleran ice sheet in Idaho [abs.]. Geological Society of America Abstracts with Programs, 42(5), 309.

Bretz, J H., 1969. The Lake Missoula floods and the Channeled Scabland. J. Geol. 77, 505-543. https://doi.org/10.1086/627452.

Bretz, J H., 1932. The Grand Coulee. American Geographical Society, Special Publication No. 15, New York. https $/ /$ doi.org/10.1017/S0016756800098010.

Bretz, J H., 1930. Valley deposits immediately west of the Channe ed rcabland. J. Geol. 38, 385-422. https://doi.org/10.1086/623737

Bretz, J H., 1929a. Valley deposits immediately east of the Chanı.2led Scabland of Washington I. J. Geol. 37, 393-427. https://doi.org/10.1086/623636.

Bretz, J H., 1929b. Valley Deposits Immediately . 7 st of the Channeled Scabland of Washington. II. J. Geol. 37, 505-541. https://doi.org/1Г. . 786; 523636.

Bretz, J H., 1928a. Bars of Channel a Scabland. Bull. Geol. Soc. Am. 39, 643-701. https://doi.org/10.1130/GSAb $29-643$

Bretz, J H., 1928b. Chan. ‘k.1 c cabland of eastern Washington. Geogr. Rev. 18, 446-477. https://doi.org/10.230 „, 208027.

Bretz, J H., 1927a. Channeled Scabland and the Spokane Flood. Jour. Wash. Acad. Sci. 17, $200-211$.

Bretz, J H., 1927b. What caused the Spokane Flood [abs.]? Bull. Geol. Soc. Am. 28, 107.

Bretz, J H., 1925a. The Spokane Flood beyond the Channeled Scablands (I). J. Geol. 33, 97-115. https://doi.org/10.1086/623179

Bretz, J H., 1925b. The Spokane Flood beyond the Channeled Scablands (II). J. Geol. 33, 236-259. 
https://doi.org/10.1086/623197

Bretz, J H., 1924. The Dalles Type of River Channel. J. Geol. 32, 139-149. https://doi.org/10.1086/623074.

Bretz, J H., 1923a. Glacial drainage on the Columbia Plateau (with discussion by M. M. Leighton and O. E. Meinzer). Bull. Geol. Soc. Am. 34, 573-608. https://doi.org/10.1130/GSAB-34-573.

Bretz, J H., 1923b. The Channeled Scablands of the Columbia Plateau. J Geol. 31, 617-649. https://doi.org/10.1086/623053.

Bretz, J H., Smith, H.T.U., Neff, G.E., 1956. Channeled scablanr ( $₹$ W shington: New data and interpretations. Bull. Geol. Soc. Am. 67, 957-1049. htt s//`’1.org/10.1130/00167606(1956)67[957:CSOWND]2.0.CO;2

Bright, R.C., 1963. Pleistocene Lakes Thatcher si $^{1}$ b. nneville, Southeastern Idaho. University of Minnesota.

Bronk Ramsey, C., 2009. Bayesian analy si 0 radiocarbon dates. Radiocarbon 51, 337-360. https://doi.org/10.1017/S00338'2_’00u33865

Brunner, C.A., Normark, W.R., 7uf a, G.G., Serra, F., 1999. Deep-sea sedimentary record of the late

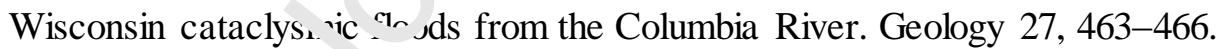
https://doi.org/10.113viv091-7613(1999)027\%3C0463:DSSROT\%3E2.3.CO;2

Buehler, J.S., Shearer, P.M., 2010. Pn tomography of the western United States using USArray. Jour. Geophys. Res., 115, B09315. https://doi.org/10.1029/2009JB006874

Bunker, R.C., 1982, Evidence of multiple late-Wisconsin floods from glacial Lake Missoula in Badger, Coulee, Washington. Quat. Res. 18, 17-31. https://doi.org/10.1016/0033-5894(82)90019-9

Burr, D.M., Carling, P.A., Baker, V.R. (Eds.), 2009. Megaflooding on Earth and Mars. New York, 
Cambridge University Press. ISBN-10:0521868521

Busacca, A.J., 1989. Long Quaternary record in eastern Washington, U.S.A., interpreted from multiple buried paleosols in loess. Geoderma 45, 105-122. https://doi.org/10.1016/0016-7061(89)90045-1

Busacca, A.J., McDonald, E.V., 1994. Regional sedimentation of late Quaternary loess on the Columbia Plateau: Sediment source areas and loess distribution patterns. Washington Division of Geology and Earth Resources Bulletin 80, 181-190.

Carling, P.A., Kidson, R., Cao, Z., Herget, J., 2003. Palaeohydraulics $r$. vtrume flood events; reality and myth, in Gregory, K. and Benito, G., eds., Palaeohydrology: 'Jna rstanding Global Change. Wiley, Chichester, 325-336.

Carrara, P.E., Kiver, E.P., Stradling, D.F., 1996. The sonthern linit of cordilleran ice in the Colville and Pend Oreille valleys of northeastern Washingte , duing the Late Wisconsin glaciation, Can. J. Earth Sciences, 33, 769-778. https $/ /$ doi.org/10.1 ' ' 9/e96-059

Carter, D.T., Ely, L.L., O’Connor, J.E., F_1 ’n, C.R., 2006. Late Pleistocene outburst flooding from pluvial Lake Alvord into the Ov yhu - Kiver, Oregon. Geomorphology 75, 346-367. https://doi.org/10.1016/J.GEר M. TRPH.2005.07.023

Chambers, R.L., 1984. Sed nent iry evidence for multiple glacial Lakes Missoula, in: McBane, J.D., Garrison, P.B. (Eds. I. J . orthwest Montana and Adjacent Canada. Montana Geological Society, Billings, 189-199.

Chambers, R.L., 1971. Sedimentation in glacial Lake Missoula. University of Montana, Mis soula, Missoula.

Cerling, T.E., Poreda, R.J., Rathburn, S.L., 1994. Cosmogenic ${ }^{3} \mathrm{He}$ and ${ }^{21} \mathrm{Ne}$ age of the Big Lost River flood, Snake River Plain, Idaho. Geology 22, 227-230. https://doi.org/10.1130/00917613(1994)022<0227:CHANAO>2.3.CO;2 
Clague, J.J., 1989. Cordilleran ice sheet. In: Fulton, R.J. (Ed.), Quaternary Geology of Canada and Greenland, Vol. 1. Geological Survey of Canada, Geology of Canada, Ottawa, Ontario, 40-42 (also Geological Society of America, The Geology of North America, Vol. K-1) Boulder, CO.

Clague, J.J., 1980. Late Quaternary geology and geochronology of British Columbia. Geol. Surv. Canada Paper 80-13.

Clague, J.J., 1975. Sedimentology and paleohydrology of late Wisconsinan outwash, Rocky Mountain Trench, southeastern British Columbia, in: Jopling, A.V. and McDun. Id, B.C. (Eds.), Glaciofluvial and glaciolacustrine sedimentation. Society of Economic Palenntc'nesists and Mineralogists, Special Publication 23, 223-237.

Clague, J.J., Armstrong, J.E., and Mathews, W.H. 1980. Adran e of the late Wisconsin Cordilleran ice sheet in southern British Columbia since 22000 y. BF. Quat. Res. 13, 322-326. https://doi.org/10.1016/0033-5894(80)90'60- ,

Clague, J.J., Barendregt, R., Enkin, R.J., Foit, F.F., 2003. Paleomagnetic and tephra evidence for tens of Missoula floods in southern Was': ${ }^{1}$ g. ${ }^{\prime}$. Geology 31, 247-250. https://doi.org/10.1130/00917613(2003)031<0247:PATE $>>$ 2.ᄂ.CO;2

Clarke, G.K.C., Mathews, V.I. I ack, R.T., 1984. Outburst floods from glacial Lake Missoula. Quat. Res. 22, 289-299. httu. //doi.org/10.1016/0033-5894(84)90023-1

Clynne, M.A., Calvert, A.T., Wolfe, E.W., Evarts, R.C., Fleck, R.J., Lanphere, M.A., 2008. The Pleistocene eruptive history of Mount St. Helens, Washington, from 300,000 to 12,800 years before present. U.S. Geol. Surv. Prof. Pap. 1750, 593-628. https://doi.org/10.3133/pp175028

Cochran, D.S., Warlow, J.C., 1980. Engineering and environmental geology, Mt. Tolman projet, Ferry County, Washingtion. Nespelem.

Cordero, D.I., 1997. Early to Middle Pleistocene Catastrophic Flood Deposits, The Dalles, Oregon, 
Portland State University.

Cosma, T., Hendy, I.L., 2008. Pleistocene glaciomarine sedimentation on the continental slope off Vancouver Island, British Columbia. Marine Geology 255, 45-54. https://doi.org/10.1016/j.margeo.2008.07.001

Cosma, T.N., Hendy, I.L., Chang, A.S., 2008. Chronological constraints on Cordilleran Ice Sheet glaciomarine sedimentation from core MD02-2496 off Vancouver Island (western Canada). Quat. Sci. Rev. 27, 941-955.

Craig, R.G., 1987. Dynamics of a Missoula flood, in: Mayer, L. ar 1 N. sh, D, (Eds.), Catastrophic Flooding. Allen \& Unwin, London. 305-332.

Craig, R.G., Hanson, J.P., 1985. Erosion potential from Missoula cloods in the Pasco Basin, Washington. Battelle Pacific Northwest Lab. Doc. PNL-56? 1.

Cressman, L.S., 1977. Prehistory of the Far West -homes of Vanished Peoples. University of Utah Press. ISBN 10: 0874801133

Cressman, L.S., 1960. Cultural seqre . $^{-}$es at the Dalles, Oregon-a contribution to Pacific Northwest prehistory. Transactions Ame: "an Philosophical Society 50 (10), 1-108. https://doi.org/10.2307 100.853

Currey, D.R., 1982. Lake sunneville: Selected features of relevance to neotectonic analyis. U.S. Geol. Surv. Open-File Report 82-1070. https://doi.org/10.3133/ofr821070.

Curry, R.R., Lister, J.C., Stoffel, K., 1977. Glacial history of Flathead Valley and Lake Missoula floods, in: Smith, D.G., Curry, R.R., Lister, J.C., Stoffel, K. (Eds.), Glacial Geology of Flathead Valley and Catastrophic Drainage of Glacial Lake Missoula. Geological Society of America, Rocky Mountain Section $30^{\text {th }}$ Annual Meeting, field Guide, Missoula, 14-38.

Dethier, D.P. Pessi, F.Jr., Keuler, R.F., Balzarini, M.A., Pevear, D.R., 1995. Late Wisconsinan 
glaciomarine deposition and isostatic rebound, northern Puget Lowland, Washington. Bull. Geol. Soc. Am. 107, 1288-1303. https://doi.org/10.1130/0016-7606(1995)107<1288:LWGDAI>2.3.CO;2

Davis, L.G., and 16 others, 2019. Late Upper Paleolithic occupation at Cooper's Ferry, Idaho, USA, 16,000 years ago. Science 365, 891-897. https://doi.org/10.1126/science.aax9830

Doak, S., O’Connor, J.E., Haugerud, R., 2018, Mapping the Missoula floods, eastern Washington. Geological Society of America Abstracts with Programs. 51-4.

Dawson, W.L., 1898. Glacial phenomena in Okanogan County, Washi ${ }_{\text {‘g }}$ 'n. Am. Geol. 22, 203-217.

Denlinger, R.P., O’Connell, D.R.H., 2010. Simulations of catack's nic utburst floods from Pleistocene glacial lake Missoula. Bull. Geol. Soc. Am. 122, 678-6 s9. . ttps://doi.org/10.1130/B26454.1

Denlinger, R.P. George, D.L., Cannon, C., O'Connor, '., ' Jaitt, R.B., in press. Diverse cataclysmic floods from Pleistocene glacial Lake Missoula. C u'vg al Society of America Special Paper

Evarts, R.C., and O'Connor, J.E., 2008. G rlogic Map of the Camas Quadrangle, Clark County, Washington, and Multnomah Coun.y. G. .gon, U.S. Geol. Surv. Sci. Inv. Map 3017. https://doi.org/10.3133/sim3017

Evarts, R., O’Connor, J.E., We`` R.E., Madin, I.P., 2009. The Portland Basin: A (big) river runs through it. GSA Today 4-l h h $\iota_{1}$ c/doi.org/10.1130/GSATG58A.1

Fields, R.L., Woods, P.F., Berenbrock, C., 1996. Bathymetric map of Lake Pend Oreille and Pend Oreille River, Idaho, U.S. Geol. Surv. Water-Resources Invest. Rep. 96-4189. https://doi.org/10.3133/wri964189

Flint, R.F., 1938. Origin of the Cheney-Palouse scabland tract, Washington. Bull. Geol. Soc. Am. 49, 461-524. https://doi.org/10.1130/GSAB-49-461

Flint, R.F., 1937. Pleistocene drift border in eastern Washington. Bull. Geol. Soc. Am. 48, 203-232. 
https://doi.org/10.1130/GSAB-48-203

Flint, R.R., 1936. Stratified drift and deglaciation of eastern Washington. Bull. Geol. Soc. Am., 47, 18491884. https://doi.org/10.1130/GSAB-47-1849

Flint, R.F., 1935. Glacial features of the southern Okanogan region. Bull. Geol. Soc. Am. 46, 169-194. https://doi.org/10.1130/GSAB-46-169

Flint, R.F., Irwin, W.H., 1939. Glacial geology of Grand Coulee Dam, W/ashington. Bull. Geol. Soc. Am. 50, 661-680. https://doi.org/10.1130/GSAB-50-661

Foley, L.L, 1976. Slack water sediments in the Alpowa Creek drai age Washington. Washington State University.

Fritz, W.J., Smith, G.A., 1993. Revisiting the Ninemile se ¿tion: Problems with relating glacial Lake Missoula stratigraphy to the Scabland-flor ss str tigraphy [abs.], in: EOS (Transactions, American Geophysical Union). American Geophysicaı Junion, 74, 302.

Fryxell, R., 1962. A radiocarbon limiting d’tt :or scabland flood. Northwest Science 6, 113-119.

Fulton, R.J., 1971. Radiocarbon G. xhı nology of Southern British Columbia. Geol. Surv. Canada 71, 28. https://doi.org/10.4095,'102 167.

Garcia-Castellanos, D., O \ >nnor, J.E., 2018. Outburst floods provide erodability estimates consistent with long-term landscape evolution. Sci. Rep. 8, 10573. https://doi.org/10.1038/s41598-018-28981$\mathrm{y}$

Gaylord, D.R., Foit Jr., F.F., Schatz, J.K., Coleman, A.J., 2001. Smith Canyon dune field, Washington, U.S.A.: relation to glacial outburst floods, the Mazama eruption, and Holocene paleoclimate. Jour. Arid Environ. 47, 403-424. https://doi.org/10.1006/jare.2000.0731

Gaylord, D.R., Meyer, S.E., Breckenridge, R.N., 2016. Glacial Lake Columbia Sedimentation: 
Sedimentology and Stratigraphy of Late Quaternary Megaflood-Influenced Sedimentary Deposits in the Latah Creek Valley near Spokane, Washington, in: Baker, V.R., Bjornstad, B.N., Gaylord, D.R., Smith, G.A., Meyer, S.E., Alho, P., Breckenridge, R.M., Sweeney, M.R., Zreda, M., 2016.

Pleistocene megaflood landscapes of the Channeled Scabland, in: Exploring the Geology of the Inland Northwest. Geological Society of America, 18-26. https://doi.org/10.1130/2016.0041(01)

Gerstel, W.J., Palmer, S.P., 1994. Geologic and geophysical mapping of the Spokane Aquifer-Relevance to growth management. Washington Geol. 22, 18-24.

Gilbert, G.K., 1890. Lake Bonneville, U.S. Geol. Surv. Monograph 1 1. ${ }^{4+n}, / /$ doi.org/10.3133/m1

Gleason, A., Markert, J., 2019. Washington State Lidar Plan: $\Lambda$ ト` $\eta$ for Statewide Lidar Coverage in Washington. Olympia. https://www.dnr.wa.gov/publicatio ‘/ger_wa_lidar_plan_2019.pdf (accessed Nov. 7, 2019).

Gilmour, D.M., Butler, V.L., O'Connor, J.E., L. ‘ ss, E.B., Culleton, B.J., Kennett, D.J., Hodgins, G., 2015. Chronology and Ecology of Late Pleistocene Megafauna in the Northern Willamette Valley, Oregon. Quat. Res. 83, 127-136 ‘-tp. ./ doi.org/10.1016/j.yqres.2014.09.003

Glenn, J.L., 1965. Late Quaterna.y su dimentation and geologic history of the North Willamette Valley, Oregon. Oregon State 'sin'ensity.

Gombiner, J.H., Hemming ‘.R., Hendy, I.L., Bryce, J.G., Blichert-Toft, J., 2016. Isotopic and elemental evidence for Scabland Flood sediments offshore Vancouver Island. Quat. Sci. Rev. 139, 129-137. https://doi.org/10.1016/j.quascirev.2016.02.026

Gordon, G., Haugerud, R., and O’Connor, J.E., 2017. Mapping the Missoula floods: The Columbia River Gorge. Geological Society of America Abstracts with Programs, 49. https://doi.org/10.1130/abs/2017AM-301734.

Goudie, A.S., 2008. The Quaternary, in: Burt, T.P., Chorley, R.J., Brunsden, D., Cox, H.J., and Goudie, 
A.S. (Eds.), The history of the study of landforms or the development of geomorphology, volume 4, Quaternary and recent processes and forms (1890-1965) and the mid-century revolutions. Chapter 10, 397-509. London, The Geological Society. ISBN 10: 1862392498

Gould, S. J. 1978. The great scablands debate. Natural History, 87, 12-18.

Gould, S.J., 1980. The Great Scablands Debate, in: The Panda's Thumb: More Reflections in Natural History. Norton, New York, 194-203. ISBN: 9780393013801.

Griggs, G.B., Kulm, L.D., Waters, A.C., Fowler, G.A., 1970. Deep-Se ^rav 21 from Cascadia Channel. J. Geol. 78, 611-619. https://doi.org/10.1086/627560

Hanson, L.G., 1970. The Origin and Deformation of Moses ( ouı e and Other Scabland Features on the Waterville Plateau. University of Washington.

Hanson, M.A., 2013, Sedimentological and palf un ag, atic study of glacial Lake Missoula lacustrine and flood sediment. Simon Fraser University. $h_{\iota_{1}} \cdot / /$ summit.sfu.ca/item/12949

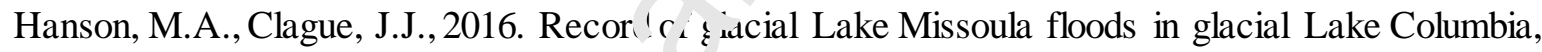
Washington. Quat. Sci. Rev. 13, 62-76. https://doi.org/10.1016/j.quascirev.2015.12.009

Hanson, M.A., Enkin, R.J., Baı ndr :gt, R.W., and Clague, J.J., 2015. Provenance and deposition of glacial Lake Misson'? ntrine and flood sediments determined from rock magnetic properties. Quat. Res. 83, 166-1il, https://doi:10.1016/j.yqres.2014.09.005.

Hanson, M.A., Lian, O.B., Clague, J.J., 2012. The sequence and timing of large late Pleistocene floods from glacial Lake Missoula. Quat. Sci. Rev. 31, 67-81. 10.1016/j.quascirev.2011.11.009

Harpel, C.J., 1996. Paleodischarges andinferred hydraulics of the Missoula Ffloods: Columbia River valley and Channeled Scabland, eastern Washington, Western Washington University Senior Thesis.

Harpel, C.J., Waitt, R.B., and O'Connor, J.E., 2000, Paleodischarges of the late Pleistocene Missoula 
floods, eastern Washington, U.S.A. [abs.]: Orkustofnun Rept. OS-2000/036, Reykjavik, Extremes of the Extremes Conference, 21.

Hendrick, M., Haugerud, R., O’Connor, J.E., 2017. Mapping the Missoula floods: North-central Washington, Geological Society of America Abstracts with Programs. v. 49, no. 6. https://doi.org/10.1130/abs/2017AM-301715

Hendy, I., 2009. A fresh perspective on the Cordilleran Ice Sheet. Geology 37, 95-96. https://doi.org/10.1130/focus012009.1

Hibbert, D., 1985. Quaternary geology and the history of the lands ape along the Columbia River between Chief Joseph and Grand Coulee Dams. in: Camnhe.' S.K., ed., Summary of Results, Chief Joseph Dam Cultural Resources Project, Washington. Otı. e of Public Archaeology Institue for Environmental Studies, University of Washingtor $65-145$. https://apps.dtic.mil/docs/citations/ADA 1 , 671 J

Hodge, E.T., 1938. Geology of the Lower Cu rmbia River. Bull. Geol. Soc. Am. 49, 831-930. https://doi.org/10.1130/GSAB-49 ○31

Hodge, E.T., 1934. Origin of the ' $\mathrm{Va}_{\llcorner}$hington scabland. Northwest Science 8, 4-11.

Hodge, E.T., 1931. Exc ^pti nal noraine-like deposits in Oregon. Bull. Geol. Soc. Am. 42, 985-1010. https://doi.org/10.1130// jSAB-42-985

Hoffman, M.H., Hendrix, M.S., 2010. Depositional processes and the inferred history of ice-margin retreat associated with the deglaciation of the Cordilleran Ice Sheet: The sedimentary record from Flathead Lake, northwest Montana, USA. Sed. Geol. 223, 61-74. https://doi.org/10.1016/j.sedgeo.2009.10.004

Hunt, C.B., 1982. Pleistocene Lake Bonneville, ancestral Great Salt Lake, as described in the notebooks of G. K. Gilbert, 1875-1880. Brigham Young Univ. Geol. Stud. 29, 225. 
Jones, F.O., Embody, D.R., Peterson, W.L, Hazlewood, R.M., 1961. Landslides along the Columbia River Valley, northeastern Washington. U.S. Geol. Surv. Prof. Pap. 367. https://doi.org/10.3133/pp367

Jarrett, R.D., Malde, H.E., 1987. Paleodischarge of the late Pleistocene Bonneville Flood, Snake River, Idaho, computed from new evidence. Bull. Geol. Soc. Am. 99, 127-134. https://doi.org/10.1130/0016-7606(1987)99<127:POTLPB>2.0.CO;2

Kahle, S.C., Bartolino, J.R., 2007. Hydrogeologic Framework and Ground-'Vater Budget of the Spokane Valley-Rathdrum Prairie Aquifer, Spokane County, Washingtnn . nd Bonner and Kootenai Counties, Idaho. U.S. Geol. Surv. Sci. Inv. Rep. 5007-504: htıs://doi.org/10.3133/sir20075041

Keszthelyi, L.P., Baker, V.R., Jaeger, W.L., Gaylord, D.R., Bృ . nstad, B.N., Greenbaum, N., Self, S., Thordarson, T., Porat, N., Zreda, M.G., 2009. $\mathrm{Fl}^{\mathrm{l}} \mathrm{O}$.s , f water and lava in the Columbia River Basin: Analogs for Mars, in: Volcanoes to Vine ard ,: Geologic Field Trips through the Dynamic Landscape of the Pacific Northwest. ``ological Society of America, 845-874. https://doi.org/10.1130/2009.fld015(3)

Kiver, E.P., Stradling, D.F., 1985. 'omı ' onts on "Periodic Jökulhlaups from Pleistocene Glacial Lake Missoula-New Evidence cror 1 Varved Sediments in Northern Idaho and Washington,” by Richard B. Waitt, Jr. Quat. Is's. 21, 354-356. https://doi.org/10.1016/0033-5894(85)90057-2

Kiver, E.P., Stradling, D.F., 1982. Upper Columbia River terrace system of eastern WashingtonPreliminary interpretations [abs], in: American Quaternary Association Program and Abstracts. American Quaternary Association, 117. ISSN: 0741-059X.

Kiver, E.P, Stradling, D.F., 1989. The Spokane Valley and northern Columbia Plateau, in: Breckenridge, R.M., Atwater, B.F., Baker, V.R., Busacca, A.J., Chambers, R.L., Curry, R.R., Hanson, L.G., Kever, E.P., McDonald, E. V., Stradling, D.F., Waitt, R.B., 1989. Glacial Lake Missoula and the Channeled Scabland, in: International Geological Congress, 28th, Guidebook. American Geophysical Union, 
Washington D.C., 23-35. https $/ /$ doi.org/10.1029/FT310

Kiver, E.P., Stradling, D.F., 1995. Geology of the Franklin D. Roosevelt Shoreline: Glacial geology, terraces, landslides, and lineaments. Grand Coulee Power Office, Bureau of Reclamation, United States Department of the Interior. https://archive.org/details/geologyoffrankli00kive/

Kiver, E.P., Stradling, D.F., and Moody, U.L., 1989. Glacial and multiple flood history of the northern borderlands - Trip B, in: Joseph, N.L., and others [Eds.], Geologic guidebook for Washington and adjacent areas. Washington Division of Geology and Earth Resource. Information Circular 86, 321335.

Kiver; E.P.; Moody; U.L.; Rigby; J.G.; and Stradling; D.F.; 1001, ' ate Quaternary stratigraphy of the Channeled Scabland and adjacent areas; in Baker; V.R ; L. rrnstad; B.N.; Busacca; A.J.; Fecht;

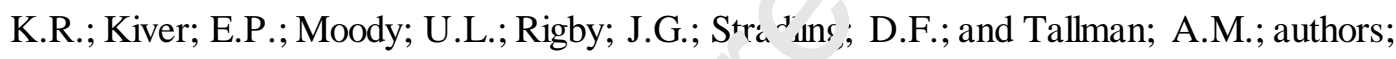
Quaternary Geology of the Columbia Pr , ear , in Morrison; R.G.; ed.; Quaternary Nonglacial Geology; Conterminous U.S.: Boulde. Colorado; Geological Society of America; Geology of North America; v. K-2; 238-250. https //a ji or , 10.1130/DNAG-GNA-K2.

Komatsu, G., Miyamoto, H., Ito, K Tosaka, H., Tokunaga, T., 2000. The Channeled Scabland: Back to Bretz?: Comment and Rep:- (jeology 28, 573. https://doi.org/10.1130/0091-

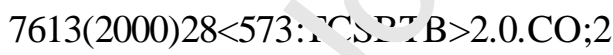

Konizeski, R.L., Brietkrietz, A., McMurtrey, R.G., 1968. Geology and ground water resources of the Kalispell Valley, northwestern Montana. Montana Bureau of Mines and Geology Bulletin 68, Butte.

Kovanen, D.J., Slaymaker, O., 2004. Glacial imprints of the Okanogan Lobe, southern margin of the Cordilleran Ice Sheet. J. Quat. Sci. 19, 547-565. https://doi.org/10.1002/jqs.855

Kuehn, S.C., Froese, D.G., Carrara, P.E., Foit, F.F., Pearce, N.J.G., Rotheisler, P., 2009. Major- and trace-element characterization, expanded distribution, and a new chronology for the latest 
Pleistocene Glacier Peak tephras in western North America. Quat. Res. 71, 201-216. https://doi.org/10.1016/j.yqres.2008.11.003

Lamb, M.P., Dietrich, W.E., Aciego, S.M., Depaolo, D.J., Manga, M., 2008. Formation of Box Canyon, Idaho, by megaflood: implications for seepage erosion on Earth and Mars. Science 320, 1067-1070. https://doi.org/10.1126/science.1156630

Lamb, M.P., Mackey, B.H., Farley, K.A., 2014. Amphitheater-headed canyons formed by megaflooding at Malad Gorge, Idaho. Proc. Natl. Acad. Sci. U. S. A. 111, 57-62. https://doi.org/10.1073/pnas.1312251111

Lapôtre, M.G.A., Lamb, M.P., Williams, R.M.E., 2016. Canynn 1ヶ "mation contraints on the discharge of catastrophic outburst floods of Earth and Mars. J. Georhy _ Res. Planets. 121, 1232-1263. https://doi.org/10.1002/2016JE005061

Larsen, I.J., Lamb, M.P., 2016. Progressive inc ${ }^{i}$, n of the Channeled Scablands by outburst floods. Nature 538, 229-232. https://doi.org/10.: 738/nature 19817

Lesemann, J.-E., Brennand, T.A., 20ก \%. n `gional reconstruction of subglacial hydrology and glaciodynamic behaviour aing the southern margin of the Cordilleran Ice Sheet in British Columbia, Canada and in thuin Washington State, USA. Quat. Sci. Rev. 28, 2420-2444. https://doi.org/10.1010, ' 'QUASCIREV.2009.04.019

Levish, D.R., 1997. Late Pleistocene sedimentation in glacial Lake Missoula and revised glacial history of the Flathead Lobe of the Cordilleran Ice Sheet, Mission valley, Montana. Boulder.

Lewis, R.S., Burmester, R.F., Breckenridge, R.M., McFaddan, M.D., Kauffman, J.D., 2002. Geologic Map of the Coeur d'Alene 30 x 60 Minute Quadrangle, Idaho. Idaho Geol. Surv. Geol. Maps GM33.

Lillquist, K., Lundblad, S., Barton, B.R., 2005. The Moxee (Washington) mammoth morphostratigraphic, 
taphonomic, and taxonomic considerations. Western North American Naturalist 65, 417-428.

Liu, T., Baker, V.R., 2018. Modeling Megafloods: Using 2D Hydraulic Simulation to Understand the Megaflood Landscapes of the Northwestern U.S. Am. Geophys. Union, Fall Meet.

Locke, W., 1995. Modeling of icecap glaciation of the northern Rocky Mountains of Montana. Geomorphology 14, 123-130. https://doi.org/10.1016/0169-555X(95)00053-5

Lonn, J.D., McDonald, C., Sears, J.W., Smith, L.N., 2010. Geologic man of the Missoula East 30’ x 60' quadrangle, western Montana, Montana Bureau of Mines and Ger ${ }_{i v i} v \mathrm{v}$ Jpen-File Report. Butte.

Lonn, J.D., Smith, L.N., McCulloch, R.B., 2007. Geologic map rf 'he J lains 30’ x 60' quadrangle, western Montana, Montana Bureau of Mines and Geolc sy `Tpen-File Report. Butte.

Lopes, C., Mix, A.C., 2009. Pleistocene megafloods in inf Northeast Pacific. Geology 37, 79-82. https://doi.org/10.1130/G25025A.1

MacEachern, J.A., Roberts, M.C., 2013. Ic:nological evidence of jökulhlaup deposit recolonization from the Touchet Beds, Mabton, WA, U.; . . ', uat. Res. 79, 37-48. https://doi.org/10.1016/j.yqres $2 \iota^{12.09 .001 ~}$

Malde, H.E., 1968. The catastru rhic late Pleistocene Bonneville flood in the Snake River Plain, Idaho.

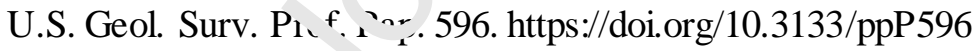

Malde, H.E., 1960. Evidence in the Snake River Plain, Idaho, of a catastrophic flood from Pleistocene Lake Bonneville. U.S. Geol. Surv. Prof. Pap. 400-B. https://doi.org/10.3133/pp400B

Malde, H.E., Powers, H.A., 1962. Upper Cenozoic Stratigraphy of Western Snake River Plain, Idaho. Geol. Soc. Am. Bull. 73, 1197-1220. https //doi.org/10.1130/00167606(1962)73[1197:ucsows]2.0.co;2

Martin, R.O.R., Hanson, R.L., 1966. Reservoirs in the United States. U.S. Geol. Surv. Water Supply 
Paper 1838. https://doi.org/10.3133/wsp1838.

McDonald, E.V., Sweeney, M.R., Busacca, A.J., 2012. Glacial outburst floods and loess sedimentation documented during Oxygen Isotope Stage 4 on the Columbia Plateau, Washington State. Quat. Sci. Rev. 45, 18-30. https://doi.org/10.1016/j.quascirev.2012.03.016

McDonald, E. V., Busacca, A.J., 1992. Late Quaternary stratigraphy of loess in the Channeled Scabland and Palouse regions of Washington state. Quat. Res. 38, 141-156. https://doi.org/10.1016/00335894(92)90052-K

McDonald, E. V., Busacca, A.J., 1988. Record of pre-late Wiscons $n$ g. int floods in the Channeled Scabland interpreted from loess deposits. Geology 16, 778-, 21 . https://doi.org/10.1130/00917613(1988)016<0728:ROPLWG>2.3.CO;2

Medley, E., 2012. Ancient Cataclysmic Floods in th: Paunic Northwest: Ancestors to the Missoula Floods. Portland State University. http://a` ,rg/10.15760/etd.581

Meinzer, O.E., 1918. The glacial history ' 1 he Columbia River in the Big Bend Region. Washingt. Acad. Sci. J. 8, 411-412.

Meyer, S.E., 1999. Depositional his 'ry of pre-late and late Wisconsin outburst flood deposits in northern Washington and I $\mathrm{r}$ ahc An ılysis of flood paths and provenance. Washington State University, Pullman.

Miller, D.M., 2016. The Provo shoreline of Lake Bonneville. Dev. Earth Surf. Process. 20, 127-144. https://doi.org/10.1016/B978-0-444-63590-7.00007-X

Miller, D.M., Oviatt, C.G., McGeehin, J.P., 2013. Stratigraphy and chronology of Provo shoreline deposits and lake-level implications, late Pleistocene Lake Bonneville, eastern Great Basin, USA. Boreas 42, 342-361. doi:10.1111/j.1502-3885.2012.00297.x

Minervini, J.M., O’Connor, J.E., Wells, R.E., 2003. Maps Showing Inundation Depths, Ice-Rafted 
Erratics, and Sedimentary Facies of Late Pleistocene Missoula Floods in the Williamette Valley,

Oregon. U.S. Geol. Surv. Open-File Rep. 03-408. https://pubs.usgs.gov/of/2003/of03-408/.

Miyamoto, H., Itoh, K., Komatsu, G., Baker, V.R., Dohm, J.M., Tosaka, H., Sasaki, S., 2006. Numerical simulations of large-scale cataclysmic floodwater: A simple depth-averaged model and an illustrative application. Geomorphology 76, 179-192. https://doi.org/10.1016/J.GEOMORPH.2005.11.002

Miyamoto, H., Komatsu, G., Baker, V.R., Dohm, J.M., Ito, K., Tosaka, H., ग007. Cataclysmic Scabland flooding: Insights from a simple depth-averaged numerical mode. ${ }^{{ }^{2}}$. viron. Model. Softw. 22, 1400-1408. https://doi.org/10.1016/j.envsoft.2006.07.006

Moody, U.L., 1978. Microstratigraphy, paleoecology, and teph schronology of the Lind Coulee site, central Washington. Washington State University ${ }^{\Gamma}$ h. $\left.{ }^{\prime}\right)$ thesis.

Moody, U.L., 1987. Late Quaternary stratigrap..: of the Channeled Scabland and adjacent areas. University of Idaho Ph.D. thesis.

Mullineaux, D.R., Wilcox, R.E., Ebaı gh, 'V.F., Fryxell, R., 1978. Age of the Last Major Scabland Flood of the Columbia Plateau in Fası 'rn Washington. Quat. Res. 10, 171-180

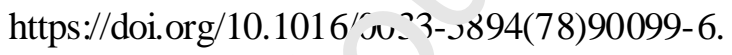

Newcomb, R.C., 1969. Effer $t$ of tectonic structure on the occurrence of ground water in the basalt of the Columbia River Group of The Dalles area, Oregon and Washington. U.S. Geol. Surv. Prof. Pap. 383-C,. https://doi.org/10.3133/pp383C

Normark, W.R., Reid, J.A., 2003. Extensive Deposits on the Pacific Plate from Late Pleistocene North American Glacial Lake Outbursts. J. Geol. 111, 617-637. https://doi.org/10.1086/378334

O’Connor, J.E., 2016. The Bonneville Flood—A Veritable Débâcle. Dev. Earth Surf. Process. 20, 105126. https://doi.org/10.1016/B978-0-444-63590-7.00006-8 
O’Connor, J.E., 1993. Hydrology, Hydraulics, and Geomorphology of the Bonneville Flood, Geological Society of America Special Paper 274. Boulder. https://doi.org/10.1130/SPE274-p1

O’Connor, J.E., Baker, V.R., 1992. Magnitudes and implications of peak discharges from glacial Lake Missoula. Bull. Geol. Soc. Am. 104, 267-279. https://doi.org/10.1130/00167606(1992)104<0267:MAIOPD>2.3.CO;2

O’Connor, J.E., Burns, S.F., 2009. Cataclysms and controversy-Aspects of the geomorphology of the Columbia River Gorge, in: Volcanoes to Vineyards: Geologic Field i.ips through the Dynamic Landscape of the Pacific Northwest. Geological Society of Amer ` '37-251. https://doi.org/10.1130/2009.fld015(12)

O’Connor, J.E., Clague, J.J., Walder, J.S., Manville, V., Beebe、 R.A., 2013. 9.25 Outburst Floods. Treatise Geomorphol. 475-510. https://doi.org/10. 1'J1t/B978-0-12-374739-6.00251-7

O’Connor, J.E., Sarna-Wojcicki, A., Wozniak, `` ¿., Polette, D.J., Fleck, R.J., 2001. Origin, Extent, and Thickness of Quaternary Geologic Units in the Willamette Valley, Oregon. U.S. Geol. Surv. Prof.

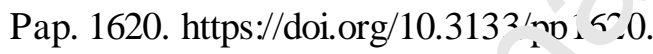

O’Connor, J.E., Waitt, R.B., 199_ b. vond the Channeled Scabland; a field trip to Missoula flood features in the Columb a, Vainma, and Walla Walla valleys of Washington and Oregon; Part 3; Field trip, days two anı ${ }^{1}$ three. Oregon Geol, Oregon Geology 57, 99-115. ISSN: 0164-3304.

Othberg, K.L., Kauffman, J.D., and Gillerman, V.S. and Garwood, D.L., 2012. Geologic Map of the Twin Falls 30 x 60 Minute Quadrangle, Idaho. Idaho Geological Survey. Geologic Map 49.

Oviatt, C.G., 2015. Chronology of Lake Bonneville, 30,000 to 10,000 yr B.P. Quat. Sci. Rev. 110, 166171. https://doi.org/10.1016/J.QUASCIREV.2014.12.016

Oviatt, C.G., Jewell, P.W., 2016. The Bonneville Shoreline: Reconsidering Gilbert's Interpretation. Dev. Earth Surf. Process. 20, 88-104. https://doi.org/10.1016/B978-0-444-63590-7.00005-6 
Oviatt, C.G., Shroder, J.F., 2016. Lake Bonneville: A Scientific Update, 1st ed. Elsevier. ISBN: 9780444635907.

Pardee, J.T., 1942. Unusual Currents in Glacial Lake Missoula, Montana. Bull. Geol. Soc. Am. 53, 15691600. https:/doi.org/10.1130/GSAB-53-1569

Pardee, J.T., 1918. Geology and mineral deposits of the Colville Indian Reservation, Washington. U.S. Geol. Surv. Bull. 186. https://doi.org/10.3133/b677

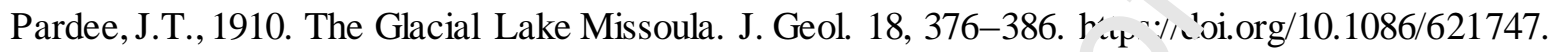

Parker, S., 1844. Journal of an exploring tour beyond the Rocky $\mathrm{Y}$ int ins : under the direction of the A. B. C. F. M. containing a description of the geography, eon gy, climate, production of the country, and the numbers, manners, and customs of the natives. Witı a map of Oregon Territory ( $4^{\text {th }}$ ed.). , Andrus, Woodruff, \& Gauntlett, Ithaca, N.Y. Kitps:ıic.cn.loc.gov/17015014

Patton, P.C., Baker, V.R., 1978b. New evidence 1 - pre-Wisconsin flooding in the channeled scabland of eastern Washington. Geology 6,567-.-71. https $/ /$ doi.org/10.1130/00917613(1978)6<567:NEFPFI $>2.0(\mathrm{O} ; 2$

Patton, P.C., Baker, V.R., 1978a. C igin of The Cheney-Palouse Scabland Tract, in: Baker, V.R., Nummedal, D. (Ers.), The Channeled Scabland. National Aeronautics and Space Administration Planetary Geology Pro, ram, Washington, D.C., 117-130.

Pederson, J.L., Janecke, S.U., Reheis, M.C., Kaufman, D.S., Oaks, R.Q., 2016. The Bear River's History and Diversion: Constraints, Unsolved Problems, and Implications for the Lake Bonneville Record. Dev. Earth Surf. Process. 20, 28-59. https://doi.org/10.1016/B978-0-444-63590-7.00002-0

Perron, J.T., Venditti, J.G., 2016. Megafloods downsized. Nature 538, 174-175. https://doi.org/10.1038/538174a

Peters, J.L., Brennand, T.A., 2020. Palaeogeographical reconstruction and hydrology of glacial Lake 
Purcell during MIS 2 and its potential impact on the Channeled Scabland, USA. Boreas https://doi.org/10.1111/bor.12434

Peterson, C.D., Minor, R., Peterson, G.L., Gates, E.B., 2011. Pre-and post-Missoula flood geomorphology of the Pre-Holocene ancestralColumbia River Valley in the Portland forearc basin, Oregon and Washington, USA. Geomorphology 129, 276-293. https://doi.org/10.1016/J.GEOMORPH.2011.02.022

Pluhar, C.J., Bjornstad, B.N., Reidel, S.P., Coe, R.S., 2006. Magnetostrauy:aphic evidence from the Cold Creek bar for onset of ice-age cataclysmic floods in eastern Wacting on during the early Pleistocene. Quat. Res. 65, 123-135. https//doi.org/10.101•/j.учıеs.2005.06.011

Porter, S.C., 1978. Glacier Peak tephra in the North Cascade k. 'ge, Washington: Stratigraphy, distribution, and relationship to late-glacial event. Q1 at. Res. 10, 30-41. https://doi.org/10.1016/0033-5894(78)90'/11- I

Praetorius, S.K., Condron, A., Mix, A.C., W'a'zak, M.H., McKay, J.L., Du, J., 2020. The role of northeast Pacific meltwater even+ in to glacial climate change. Science Advances 6. https://doi.org/10.1126/sciadv. 'ay'L̇15

Prytulak, J., Vervort, J.D., ra.'k, 1., Yu, C, 2006. Astoria Fan sediments, DSDP site 174, Cascadia Basin: Hf-Nd-Pb con ${ }^{~}$ raints on provenance and outburst flooding. Chem. Geol. 233, 276-292. https://doi.org/10.1016/j.chemgeo.2006.03.009

Rathburn, S.L., 1993. Pleistocene cataclysmic flooding along the Big Lost River, east central Idaho. Geomorphology 8, 305-319. https://doi.org/10.1016/0169-555X(93)90026-X

Richmond, G.M., Fryxell, R., Neff, G.E., Weis, P.L., 1965. The Cordilleran ice sheet of the northern Rocky Mountains, and related Quaternary history of the Columbia Plateau, in: Wright, H.E., Frey, D.G. (Eds.), The Quaternary of the U.S. Princeton University Press, 231-242. ISBN: 
9780691624426.

Riedel, J.L., 2017, Deglaciaton of the North Cascade Range, Washington and British Columbia, from the last glacial maximum to the Holocene. Cuadernos de Investigación Geográfica 43, 467-496. https://doi.org/10.1016/0169-555X(95)00053-5

Reimer, P., and 29 others, 2013. IntCal13 and Marine 13 radiocarbon age calibration curves 0-50,000 years calBP. Radiocarbon 55, 1869-1887. https://doi.org/10.2458/azu_js_rc.55.16947

Rigby, J.G., 1982. The sedimentology, mineralogy, and depositional er.vinn..ent of a sequence of Quaternary catastrophic flood-derived lacustrine turbidites nf ar s cokane, Washington. University of Idaho, Moscow.

Russell, I.C., 1893. Geologic Reconnoissance in Central Wushing.on. U.S. Geol. Surv. Bull. 108.. https://doi.org/10.3133/b108.

Schmidt, K.L, Kauffman, J.D., Stewart, D.E., Gaı 'ood, D.L, Othberg, K.L., Lewis, R.S., 2009. Geologic Map of the Grave Point Q ia ' ${ }^{\top}$ aı.gle, Idaho County, Idaho, and Wallowa County, Oregon. Idaho Geological Survey Digital W८ h Maps DWM-111, scale 1:24,000. https://www.idahogeology.c.o/p.h/Digital_Data/Digital_Web_Maps/Lucile_DWM-126-m.pdf

Scott W.E., Pierce, K.L B. adbı cy, J.P., Forester, R.M., 1982. Revised Quaternary stratigraphy and chronology in the Ame ican Falls area, southeastern Idaho, in: Bonnichsen, B., Breckenridge, R.M. (Eds.), Cenozoic geology of Idaho. Idaho Bureau of Mines and Geology Bulletin 26, 581-595.

Shaw, J., Munro-Stasiuk, M., Sawyer, B., Beaney, C., Lesemann, J.-E., Musacchio, A., Rains, B., Young, R.R., 2000. The Channeled Scabland: Back to Bretz?: Comment and Reply. Geology 28, 577. https://doi.org/10.1130/0091-7613(2000) 28<577:TCSBTB>2.0.CO;2

Shaw, J., Munro-Stasiuk, M., Sawyer, B., Beaney, C., Lesemann, J.-E., Musacchio, A., Rains, B., Young, R.R., 1999. The Channeled Scabland: Back to Bretz? Geology 27, 605-608. 
https://doi.org/10.1130/0091-7613(1999)027

Smith, G.A., 1993. Missoula flood dynamics and magnitudes inferred from sedimentology of slack-water deposits on the Columbia Plateau, Washington. Bull. Geol. Soc. Am. 105, 77-100. https://doi.org/10.1130/0016-7606(1993) 105<0077:MFDAMI>2.3.CO;2

Smith, L.N., 2017. Repeated sedimentation and exposure of glacial Lake Missoula sediments: A lakelevel history at Garden Gulch, Montana, USA. Quat. Sci. Rev. 155, 114-126. https://doi.org/10.1016/J.QUASCIREV.2016.11.018

Smith, L.N., 2006. Stratigraphic evidence for multiple drainings of gla ial Lake Missoula along the Clark Fork River, Montana, USA. Quat. Res. 66, 311-322. httnc•/ハ่i.org/10.1016/j.yqres.2006.05.009

Smith, L.N., 2004. Late Pleistocene stratigraphy and imnlicutions for deglaciation and subglacial processes of the Flathead Lobe of the Cordiller n lu sheet, Flathead Valley, Montana, USA. Sediment. Geol. 165, 295-332. https $/ /$ dor. ${ }^{*} s / 10.1016 / j$. sedgeo.2003.11.013

Smith, L.N., Hanson, M.A., 2014. Sedim` it `ry iecord of glacial Lake Missoula a long the Clark Fork River from deep to shallow posi ions in the former lakes: St. Regis to near Drummond, Montana, in: Shaw, C.A., Tikoff, B. (Eds I, Lvploring the Northern Rocky Mountains. Geological Society of America, 51-63. https'/u i.ug/10.1130/9780813700373

Smith, L.N., Sohbati, R., Bu laert, J.-P., Lian, O.B., Murray, A., Jain, M., 2018. Timing of lake-level changes for a deep last-glacial Lake Missoula: optical dating of the Garden Gulch area, Montana, USA. Quaternary Science Reviews, 183, 23-35. https://doi.org/10.1016/j.quascirev.2018.01.009

Smyers, N.B., Breckenridge, R.M., 2003. Glacial Lake Missoula, Clark Fork ice dam, and the floods outburst area: Northern Idaho and western Montana, in: Swanson, T.W. (Ed.), GSA Field Guide 4: Western Cordillera and Adjacent Areas. Geological Society of America, Boulder, 1-15. https://doi.org/10.1130/0-8137-0004-3.1 
Spencer, P. K., 1989. A small mammal fauna from the Touchet Beds of Walla Walla County, Washington-Support for the multiple flood hypothesis. Northwest Science 63, 167-174.

Spencer, P.K., Jaffee, M.A., 2002. Pre-Late Wisconsin glacial outburst floods in southeastern Washington - the indirect record. Wash. Geol. 30, 9-16.

Spencer, P.K., and Knapp, A.N., 2010. New stratigraphic markers in the late Pleistocene Palouse loess: Novel fossil gastropods, absolute age constraints and nonaeolian facies. Sedimentology 57, 41-52. https://doi.org/10.1111/j.1365-3091.2009.01085.x

Stearns, H.T., 1962. Evidence of Lake Bonneville flood along Sna'e k ver below King Hill, Idaho. Geological Society of America Bulletin 73, 385-387. httrnc: 7606(1962)73[385:EOLBFA]2.0.CO;2.

Steele, W.K., 1991. Paleomagnetic Evidence for Rer eatui Glacial Lake Missoula Floods from Sediments of the Sanpoil River Valley, Northeasterı " ashington. Quat. Res. 35, 197-207. https://doi.org/10.1016/0033-5894(91)ฯ 767-F

Stuiver, M., Reimer, P.J., and Reimer R. V ., 2020, CALIB 7.1 [WWW program] at http://calib.org, accessed 2020-2-7.

Swanson, T.W., and Caffec M.1., 2001. Determination of ${ }^{36} \mathrm{Cl}$ production rates derived from the welldated deglaciation surf ces of Whidbey and Fidalgo Islands, Washington. Quat. Res. 56, 366-382. https://doi.org/10.1006/qres.2001.2278

Sweeney, M.R., Gaylord, D.R., Busacca, A.J., 2007. The evolution of eureka flat: a dust producing engine of the Palouse loess, USA. Quaternary International 162,163, 76-96. https://doi.org/10.1016/j.quaint.2006.10.034

Symons, T.W., 1882. Report of an examination of the upper Columbia river and the territory in its vicinity in September and October, 1881, to determine its navigability, and adaptability to steamboat 
transportation.: Made by direction of the commanding general of the Department of the Columbia, U. S.. 47th Cong., 1st sess. Senate. Ex. Doc. 186. Government Printing Office, Washington.

Thorson, R. M., 1989. Glacio-isostatic response of the Puget Sound area, Washington. Geological Society of America Bulletin, 101, 1163-1174. https://doi.org/10.1130/00167606(1989)101<1163:GIROTP>2.3.CO;2

Trimble, D.E., 1963. Geology of Portland, Oregon, and adjacent areas. U.S. Geol. Surv. Bull. 1119. https://doi.org/10.3133/b1119

Trimble, D.E., Carr, W.J., 1961. The Michaud delta and Bonnevill Kı er near Pocatello, Idaho. U.S. Geol. Surv. Prof. Paper 424-B, B164-B166. https://doi.rro/^` 3133/pp424B

Vanaman, K. M., O’Connor, J. E. and Riggs, N., 2006. Plei,toceıə history of Lake Millican, central Oregon [abs.]. Geological Society of America 'bsuacts with Programs 38(7), 71.

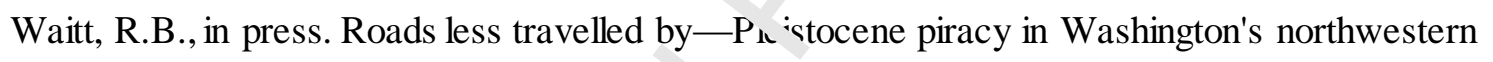
Channeled Scabland.

Waitt, R.B., 2017. Pleistocene glacirı, lakes, and floods in north-central Washington State, in: Haugerud, R.A., and Kelsey, H.M. (Eds., From the Puget Lowland to East of the Cascade Range: Geologic Excursions in the Dac fic $\perp$ orthwest. Geological Society of America Field Guide 49, 175-205. https://doi.org/10.1130/ .017.0049(08)

Waitt, R.B., 2016. Megafloods and Clovis cache at Wenatchee, Washington. Quat. Res. 85, 430-444. https://doi.org/10.1016/i.yqres.2016.02.007

Waitt, R.B., 1994. Scores of gigantic, successively smaller Lake Missoula floods through Channeled scabland and Columbia valley, in: Swanson, D.A., Haugerud, R.A. (Eds.), Geological field trips in the Pacific Northwest, Geological Society of America Annual Meeting Field Trip Guidebook 1, University of Washington, Seattle, K1-K88. 
Waitt, R.B., 1987. Erosional landscape and surficial deposits, in: Tabor, R.W., Frizzell, V.A.J., Waitt, R.B., Swanson, D.A., Byerly, G.R., Booth, D.B., Hetherington, M.J., Zartman, R.E. (Eds.), Geologic Map of the Chelan 3-Minute by 60-Minute Quadrangle, Washington. U.S. Geol. Surv. Misc. Inv. Series Map I-1661. https://doi.org/10.3133/i1661.

Waitt, R.B. 1985b. Reply to Comment on "Periodic Periodic jökulhlaups from Pleistocene glacial Lake Missoula - New evidence from varved sediment in northern Idaho and Washington." Quat. Res. 24, 357-360. https://doi.org/10.1016/0033-5894(85)90058-4

Waitt, R.B., 1985a. Case for periodic, colossal jökulhlaups from Pleictc ara glacial Lake Missoula. Bull. Geol. Soc. Am. 96, 1271-1286. https://doi.org/10.1130/00: i7606(1985)96<1271:CFPCJF>2.0.CO;2

Waitt, R.B., 1984. Periodic jökulhlaups from Pleistore gl cial Lake Missoula-New evidence from varved sediment in northern Idaho and V ash agton. Quat. Res. 22, 46-58. https://doi.org/10.1016/0033-5894(84,? $7005-X$

Waitt, R.B., 1982. Surficial geology, ir. Tín’r, R.W., Waitt, R., Frizzell, Jr., V.A., Swanson, D.A., Byerly, G.R., Bentley, R.D. ('ds.), Geologic Map of the Wenatchee 1:100,000 Quadrangle, Central Washington. U.S. Geol. Su v. Miscellaneous Investigations Map I-1311. https://pubs.usgs.go, 'in.....'11311/

Waitt, R.B., 1980. About forty last-glacial Lake Missoula jökulhlaups through southern Washington. J. Geol. 88, 653-679. https://doi.org/10.1086/628553.

Waitt, R.B., 1977a. Missoula flood sans Okanogan lobe.Geol. Soc. Am. Abstracts with Prog. 9, 770.

Waitt, R.B., 1977b. Guidebook to Quaternary geology of the Columbia, Peshastin, and upper Yakima valleys, west-central Washington: U. S. Geol. Surv. Open-File Rept. 77-753.

Waitt, R.B., Breckenridge, R.M., Kiver, E.P., Stradling, D.F., 2016. Late Wisconsin Cordilleran icesheet 
and colossal floods in northeast Washington and north Idaho, in: Cheney, E.S. (Ed.), The Geology of Washington and Beyond from Laurentia Laurentia to Cascadia. University of Washington Press, Seattle, 233-256. ISBN 978-0295995274.

Waitt, R.B., Long, W.A., Stanton, K.M, 2019. Erratics and other evidence of late Wisconsin Missoula outburst floods in lower Wenatchee and adjacent Columbia valleys, Washington. Northwest Science 92, 318-337. https://doi.org/10.3955/046.092.0503

Waitt, R.B., O’Connor, J.E., Harpel, C.J. (2000). Varying routings of repe ‘ `ed colossal jökulhlaups through the channeled scabland of Washington, USA [abs.]. Ork $\mathbf{u}^{+{ }^{+}}$nun Rept. OS-2000/036, Reykjav'ik, Extremes of the Extremes Conference, 27.

Waitt, R.B., Thorson, R.M., 1983. The Cordilleran ice sheet in vashington, Idaho, and Montana, in: Wright, H.E., Porter, S.C. (Eds.), Late-Quaternaı in ironments of the United States. University of Minnesota Press, Minneapolis, 53-70. IF 3N 778-u816669547.

Walder, J.S., Costa, J.E., 1996. Outburst flooi- from glacier-dammed lakes: The effect of mode of lake drainage on flood magnitude. Ea ${ }^{-4}$ S ir'. Process. Landforms 21, 701-723. https://doi.org/10.1002/(SICI) 996-7837(199608)21:8<701::AID-ESP615>3.0.CO;2-2

Washington Department of va. Irai Resources, Division of Geology and Earth Resources, 2016. The Cheney-Palouse tract ^ ${ }^{f}$ Washington's Channeld Scalands. https://www.dnr.wa.gov/publications/ger_presentations_coe_cheney_palouse_scablands.pdf?vqt8q (accessed Nov. 7, 2019)

Waters, A.C., 1933. Terraces and coulees along the Columbia River near Lake Che lan, Washington. Bull. Geol. Soc. Am. 44, 783-820. https://doi.org/10.1130/GSAB-44-783

Welch, E.G., Brattebo, S.K., Gibbons, H.L., Plotnikoff, R.W., 2015. A dramatic recovery of Lake Spokane water quality following wastewater phosphorus reduction. Lake and Reservoir 
Management 31 157-165. https://doi.org/10.1080/10402381.2015.1040566.

Wells, R.E., Haugerud, R.A., Niem, A.R., Niem, W.A., Ma, L., Evarts, R.C., O'Connor, J.E., Madin, I.P., Sherrod, D.R., Beeson, M.H., Tolan, T.L., Wheeler, K.L., Hanson, W.B., and Sawlan, M.G., in press. Geologic map of the greater Portland metropolitan area and surrounding region, Oregon and Washington. U.S. Geol. Surv. Sci. Inv. Map 3443.

Weis, P.L., 1968. Geologic map of the Greenacres quadrangle, Washington and Idaho. U.S. Geol. Surv. Quadrang. Map 734, 4. https://doi.org/10.3133/gq734

Weis, P.L., Richmond, G.M., 1965. Maximum extent of late Pleist se $\mathbf{L}_{\mathbf{2}}$, cordilleran glaciation in northeastern Washington and northern Idaho. U.S. Geol $\mathrm{C}_{\mathrm{II}}$ - Prof. Pap. 525-C, C128-C132. https://doi.org/doi.org/10.3133/pp525C

Woods, P.F., Berenbrock, C.E., 1994. Bathymetric "* ap vi Coeur D'Alene Lake, Idaho. U.S. Geol. Surv. Water-Resources Invest. Rep. 94-4119. hı., ://doi.org/10.3133/wri944119

Zuffa, G.G., Normark, W.R., Serra, F., B u neı, C.A., 2000. Turbidite Megabeds in an Oceanic Rift Valley Recording Jokulhlaups n La $\bullet$ Pleistocene Glacial Lakes of the Western United States. J. Geol. 108, 253-274. https:/'ºl. rg/10.1086/314404.

Figure 1. Overview map of U.S. Pacific Northwest megaflood landscape. Bonneville flood inundation modified from O'Connor (1993); Missoula flood inundation courtesy of Daniel Coe, Washington Geological Survey; 
maximum extent of Cordilleran ice sheet and adjacent glaciers based on Waitt and Thorsen (1983), Booth (1986), Clague (1989), Locke (1995), Carrara et al. (1996), Smith (2004), Riedel (2017), and unpublished mapping by Ralph Haugerud, U.S. Geological Survey. Extent of Bonneville flood downstream of Lewiston is within Missoula flood extent.

Figure 2. Profile of the Bonneville flood. Modified from O'Connor (1993, p. 11). Kilometer 0 equivalent to Snake River Mile 140.

Figure 3. Erosion by the Bonneville flood. (a) Aerial view east and upstream in the Portneuf River valley, floored by flood-eroded basalt flow. Photograph by Jim E. O'Connor. (b) Ground vit " of fluted and polished Portneuf Basalt near the scabland in (a). Shovel handle $0.5 \mathrm{~m}$. Pho' _cap... by Jim E. O'Connor. (c) Aerial view west and downstream from near Twin Falls, showing scab: 'nd and cataracts of the Devils Corral area carved by flow from the Eden Channel reentering the Snake Jivf: Canyon near Snake River Mile 617. Photograph by Bruce Bjornstad.

Figure 4. Deposits of the Bonneville flood. (a) Viev ac vns 'ream of immense boulder bar partly filling $1.5 \mathrm{~km}$ wide canyon downstream of the Swan Falls con. 'riction near Snake River Mile 457. (b) Close view of bedload on the bar in (a). Many clasts 'a $a .1$ g diameters exceeding $10 \mathrm{~m}$. (c) View north (downstream) in Hells Canyon near Snake River Mile $2 \iota^{\top}$ snowing immense point bar (with large Ponderosa Pines along river edge) and flood-swept ville, slope to nearly $200 \mathrm{~m}$ above. (d) Sand and fine gravel deposited from suspended load in an edN : ha, - st of Hagerman, Idaho. Pick is $0.7 \mathrm{~m}$ long. (e) Horizontally bedded Missoula Flood deposı. on cop of foreset bedded Bonneville Flood gravel in the Tammany Creek valley near Lewiston, Idaho, Snake River Mile 146. Here about 20 Missoula flood beds were left by that number of floods backing up the Snake River (Waitt, 1985a). The foresets in the Bonneville Flood gravel dip up Tammany Creek valley, indicating up-valley flow as the bar formed. Photographs by Jim E. O'Connor

Figure 5. Map of Channeled Scabland showing approximate last-glacial-maximum extent of Cordilleran Ice Sheet, major flood pathways, and approximate Missoula flooding extent. Glacial Lake Columbia depicted at maximum plausible $730 \mathrm{~m}$ elevation; glacial Lake Spokane at $600 \mathrm{~m}$.

Figure 6. Hypothesized Missoula-flood scenarios involving interactions with glacial Lake Columbia and the major flood pathways. Modified from Waitt (2016) and Balbas et al. (2017). Timing approximate and summarizes 
information presented in text. Not shown are possible interactions involving the Columbia lobe blocking the Spokane River and resulting glacial Lake Spokane. (a) Key geographic elements. A and A' show endpoints of profile of Figure 8. (b) Glacial Lake Missoula forms and first Missoula flood(s) pass down Spokane River and Columbia River valleys. (c) Okanogan lobe blocks Columbia Valley, impounding glacial Lake Columbia and shunts at least four Missoula floods south into Moses Coulee (Waitt, 1985a, 2016, in press). (d) Maximum Okanogan lobe ice extent, blocking entrance to Moses Coulee and possibly Grand Coulee, and raising glacial Lake Columbia to $715-730 \mathrm{~m} .$. (e) Retreated Okanogan lobe still blocks Columbia River, maintaining glacial Lake Columbia, but now lowered and stabilized by > Gra. $d$ Coulee outlet at 510-550 m level (map shows $520 \mathrm{~m}$ ). (f) Possible last-glacial incision of upper Z. nu zoulee threshold to modern threshold elevation of $\mathbf{4 7 0} \mathrm{m}$ lowers glacial Lake Columbia. Gla 기 Lake Columbia persists for at least another 200-400 years after the last Missoula flood (Atwatt: 1c 87 , p. 185-187) before possibly cataclysmically breaching its ice dam, sending a flood $d r w$ the Columbia Valley downstream of the Okanogan River confluence.

Figure 7. Glacial Lake Missoula features. (a) View no . hwest toward Missoula and Clark Fork River Valley from near the summit of $1570 \mathrm{~m}$ Mount Sen'... ᄀl, s.iowing glacial Lake Missoula shorelines etched as high as 1295 m on flanks of Mount Jumbo. Ph + ograph by Brennan D. O'Connor. (b) Ninemile stratigraphic section exposed along eastbound lancs 0. ' -90 , where multiple varved sequences separated by sand and silt beds signal dozens of draininge -f g. “al Lake Missoula (Alt and Chambers, 1970; Chambers, 1971, 1984; Waitt, 1980, 1985a, Smith, 2U``; nanson et al., 2012). The top of the section is at $959 \mathrm{~m}$. Photograph by Jim E. O’Connor. (c) Grass-covered Stout's bar, one of many high eddy bars described by Pardee (1942, p. 15891593) filling tributary valleys and gulches flanking the Clark Fork and Flathead River valleys, which became major flow conduits during lake drainage. The top of the deposit is at $1000 \mathrm{~m}, 230 \mathrm{~m}$ above modern river level; flow was from right to left. Photograph by Jim E. O’Connor.

Figure 8. Profile of key topographic, glacial, and flood features along $600 \mathrm{~km}$ of the Missoula flood route between Wenatchee, Washington, and the lower Clark Fork River valley, Idaho and far western Montana. Endpoints shown as $A$ and $A^{\prime}$ on Figure 5. Modern digital elevation profile, including modern reservoir surfaces, extracted from U.S. Geological Survey National Map 3D Elevation Program. Approximate 
historical river and valley profile derived from bathymetric and historical map information. Glacier and terrace profiles estimated from multiple sources listed in figure 1, supplemented by unpublished observations by O'Connor, Waitt, and Cannon. Estimated equilibrated isostatic response to maximum ice and lake loading (Figure $6 \mathrm{~d}$ ) is shown as deflection of the historical river and valley profile. Divide elevations are for selected low areas south of Spokane and Columbia valleys leading to Channeled Scabland tracts and coulees cut into southward sloping Columbia Plateau (as depicted in Figure 6a). Maximum flood-stage evidence from data in Table 3. Key lake levels and stratigraphic section locations and extents from sources cited in text. Glacial Missoula stratigraphic sectione ar east of the profile. The Mission Valley site is the Landslide Bend section of Levish (1993).

Figure 9. GoogleEarth image of a part of the Cheney-Palouse tract sí, wing plexus of scabland eroded into the basalt of the Columbia River Basalt Group separated by strt. ml; ied "islands" of uneroded loess uplands. Area of figure shown in Figure 5.

Figure 10. View north of upper Grand Coulee. Stea ، 10 at '. ock mid-coulee in the obscure distance. Banks Lake, hemmed in by low dams built at both ends of $t_{1}$. coulee now floods the irregular coulee bottom to 479 $\mathrm{m}, \sim 10 \mathrm{~m}$ above the historical 470-m t'., shcid at the south end of the lake. Glacial Lake Columbia sediments flanking Banks Lake incl Ide the Paynes Gulch section described by Atwater (1987, p. 192-195), as high as $486 \mathrm{~m}$, and probabl:' gı . Jed (but isostatically uplifted) to the $470-\mathrm{m}$ outlet elevation (Atwater, 1987, p. 188). Photograph hv L “ ce Bjornstad.

Figure 11. Immense fragmeı. or vasalt entablature eroded from Grand Coulee and transported to the Ephrata fan where lower Grand Coulee opens into Quincy Basin. Photograph by Jim E. O'Connor.

Figure 12. Oblique aerial view up Moses Coulee showing a portion of the Three Devils scabland complex. Bretz (1923a, p. 600; 1930 , p. 394-395) inferred these channels eroded by upstream cataract recession, as suggested by cat aracts at the head of several channels. Photograph by Bruce Bjornstad.

Figure 13. Last-glacial flood and outwash features in the Brays Landing area mapped onto hillshade digital elevation model derived from 1-m resolution lidar. Immense, bouldery, current-dune covered Missoula flood bar in point-bar position extends six $\mathbf{k m}$ downstream from eroded granite outcrops and climbs to 260 $\mathrm{m}$ above historical river level. This bar was deposited by Missoula flood(s) preceding blockage of the 
Columbia River by the Okanogan lobe. Inset against the bar complex is the mostly planar, downstream sloping cobble-gravel terrace graded to the maximum extent of a down-Columbia finger of the Okanogan lobe that terminated about $7 \mathrm{~km}$ upstream from the right figure edge. Inset against the outwash terrace is another boulder-armored flood bar, its surface mostly disturbed by housing, but still preserves a few obvious giant current dunes. This lower bar probably owes to the outburst of glacial Lake Columbia at about $\mathbf{1 4 . 5}$ ka. Associated flooding may have channeled the outwash terrace above. Figure outline shown on Figure 5. Lidar obtained from the Washington Lidar Portal (https://lidarportal.dnr.wa.gov).

Figure 14. Nearly 40 beds of Missoula flood slackwater deposits exposed in $2 n-m$. teep Burlingame Canyon within the Walla Walla River valley. This section has been analyzer : ' ‘jurnstad (1980), Waitt (1980), Moody (1987), and Clague et al. (2003), and was the key site su, nortıng Waitt's (1980) hypothesis that each bed was laid down by individual floods decades apart, hu' indicating dozens of Missoula floods. Photograph by Bruce Bjornstad.

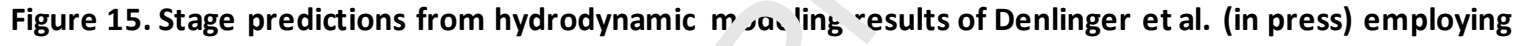
GeoClaw model (Berger et al., 2011). All modeı . 'ns fully couple drainage of glacial Lake Missoula from its maximum 1295-m level and downstrer “. ‘loc ling due to instantaneous and complete ice-dam removal. Model topography derived from 3/, m 'igıtal elevation model adjusted for ice-margin positions derived from Waitt and Thorson (198? I, r servoir inundation, and Holocene fill of the Columbia River valley below Columbia River Mile River 19८:-.ter Baker et al. (2010) downstream of River Mile 120 and supplemented by drillers logs]. Mode, - ᄏlculations implement twenty-minute model time steps. Ice-rafted erratics mark approximate maximum stages at depicted locations (Table 3). Three basic scenarios are modeled for each location: (1) Columbia Valley open to Missoula floods prior to blockage by the Okanogan ice lobe, as shown in Figure 6b; (2) Columbia Valley by blocked by Okanogan lobe but entrance to Moses Coulee open (Figure 6c); and (3) Okanogan lobe blocking Columbia Valley and entrance to Moses Coulee (d). For each of these three situations, model trials assume that the Grand Coulee threshold is either at the modern 470-m elevation or at a higher, unincised or ice-blocked $680 \mathrm{~m}$, a plausible estimate of the pre-incision elevation of the coulee entrance (Waitt, in press). (a) Spokane Valley near Spokane (47.6890, -117.1090), about 75 km downstream from ice dam. Maximum inundation is for Missoula flooding coincident with a high-level 
680-m glacial Lake Columbia. (b) Columbia River at the head of Grand Coulee (47.9406, -118.9483). Highest stages attained when Columbia River valley downstream is blocked by the Okanogan lobe. No results shown for maximum Okanogan lobe ice extent (Figure 6d) blocking Columbia Valley, Moses Coulee, and Grand Coulee because site is within presumed ice margin, but this scenario would produce highest local flood stages as indicated by Spokane-area results shown in part a. The two runs for the Columbia-Riveropen scenario produce the lowest local flood stages but also show the influence of a fully incised upper Grand Coulee diverting substantial flow, enough to reduce local maximum stage by nearly $40 \mathrm{~m}$. (c) Columbia River near Wenatchee $(47.4526,-120.3167)$. Highest flood stares . osult from unblocked Columbia Valley scenarios, allowing down-Columbia passage of $M^{\prime}$ __ ' 'llu , roods. A Grand Coulee outlet elevation of $\mathbf{4 7 0} \mathrm{m}$ diverts enough flow to reduce stages in the Venatchee area by $\mathbf{2 7} \mathrm{m}$. Yet even when Grand Coulee diverts no water, maximum calculated stages rafted erratics. The low, 470-m Grand Coulee threshr id 1: 0 markedly reduces Moses Coulee flooding, thereby eliminating backflooding to Wenatch $\approx \mathrm{e}$ rec. compared to stages $\mathbf{4 0} \mathrm{m}$ higher when Moses Coulee entrance is open, but the Grand Coulee divide is high at $680 \mathrm{~m}$. (d) Columbia River in Pasco Basin (46.1937, -119.0414). Maximum and most rapid ; in 'da.ion of Pasco Basin predicted for Missoula floods into highlevel glacial Lake Columbia. Highes. $\mathrm{m}$. Jeled floods levels of $338 \mathrm{~m}$ fall short of local field evidence of maximum stages by 20-25 m. (e) -olumbia River near Portland (45.6498, -122.756). Similar to Pasco Basin, highest and most rapid f|r--jit, sssociated with high-level glacial Lake Columbia. Maximum predicted flood st ages of $112 \mathrm{~m}$ a. ?uı $10 \mathrm{~m}$ lower than highest nearby erratics.

Figure 16. Deposits left by last-glacial, probably post-Missoula, outburst flood in the Columbia valley which we infer derived from cataclysmic emptying of ice-dammed Lake Columbia. (a) Rounded bar of bouldery gravel downstream of Methow River confluence with Columbia near River Mile 523,15 km downstream from icedam blockage area at the Okanogan River confluence. Terrestrial cosmogenic nuclide analyses of three bouldersat this site give results of $13.0 \pm 1.1 \mathrm{ka}, 13.9 \pm 1.1 \mathrm{ka}$, and 15.3 \pm 1.3 ka (Balbas et al., 2017, Table DR2). Scatter among individual boulder ages possibly owes to variable transport and exposure histories of measured boulders perhaps moved by earlier floods or by the overriding Okanogan ice lobe. Photograph by Jim E. O'Connor. (b) Upstream directed aerial view by Bruce Bjornstad of rippled West Bar from near 
Columbia River Mile 440, inferred deposited by an outburst of glacial Lake Columbia. Bar surface stands 60 m above Columbia River pool level. Inset into West Bar is another flood bar, possibly left by an outburst from glacial Lake Kootenay (Waitt, 2016).

Figure 17. Thick sequences of loess and paleosols containing strongly formed calcic horizons, capping poorly sorted but stratified and locally foreset bedded basalt cobble gravel. Such deposits indicate flood episodes prior to the last glacial period. Photographs by Jim E. O'Connor. (a) Old Maid Coulee site $(46.6045$, 118.8599) where Bjornstad et al. (2001, p. 698) reported flood gravel capped by reversed-polarity soil and >350 ka calcic horizon. (b) Marengo bar site within Cheney-Palouse scahlanı tract $(47.0126,-118.2134)$, also reported by Bjornstad (2001, p. 698) as a flood gravel overlair : ; r - crsely magnetized loess and an 800-ka calcic horizon. Hammer $40 \mathrm{~cm}$ long.

Table 1. Columbia Basin megaflood-related lakes and tran ier.t impoundment stages; depths, areas, and volumes.

Table 2. Columbia Basin megaflood discharge estima، 's.

Table 3. Evidence of maximum Missoula flor a tag s, selected from multiple sources and new observations (as noted). All sites were reevaluated Isir, modern imagery and topographic maps, result ing in many elevation and location adjustrner, < from original sources. Elevations of positive evidence of floods, such as eroded rock, crossed divin-c. ¿ ice-rafted erratics were attributed to the highest elevation contour below the feature, exa it wnere nearby benchmarks or checked elevations provided more precise information. Similarly, elevations of features inferred not flooded, such as divides not crossed, were attributed to the lowest elevation contour above the feature. Where original evidence, part icularly erratics, could not be evaluated remotely, elevation and location information are noted "as reported." ....29 
Figure 1

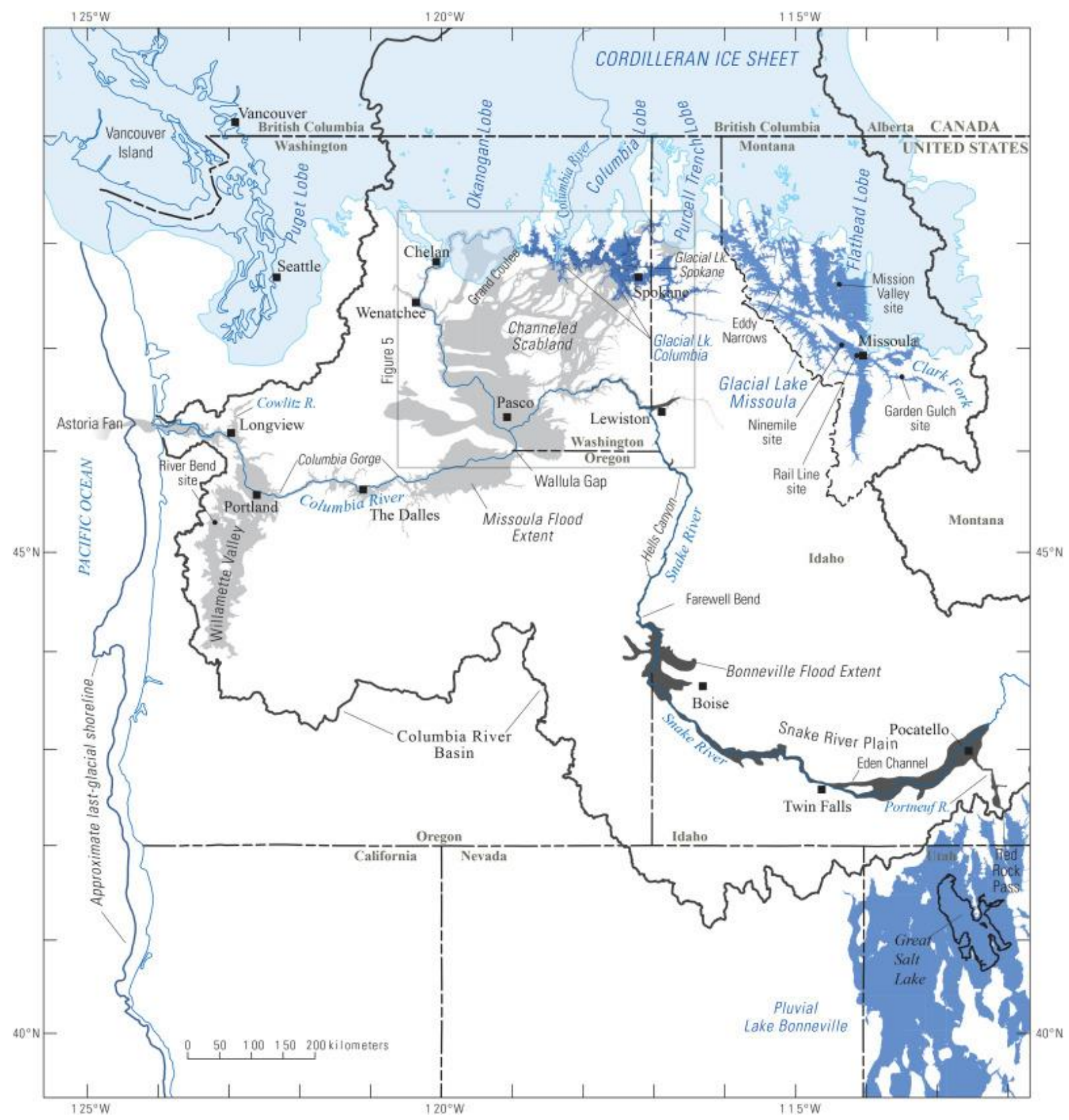




\section{Figure 2}

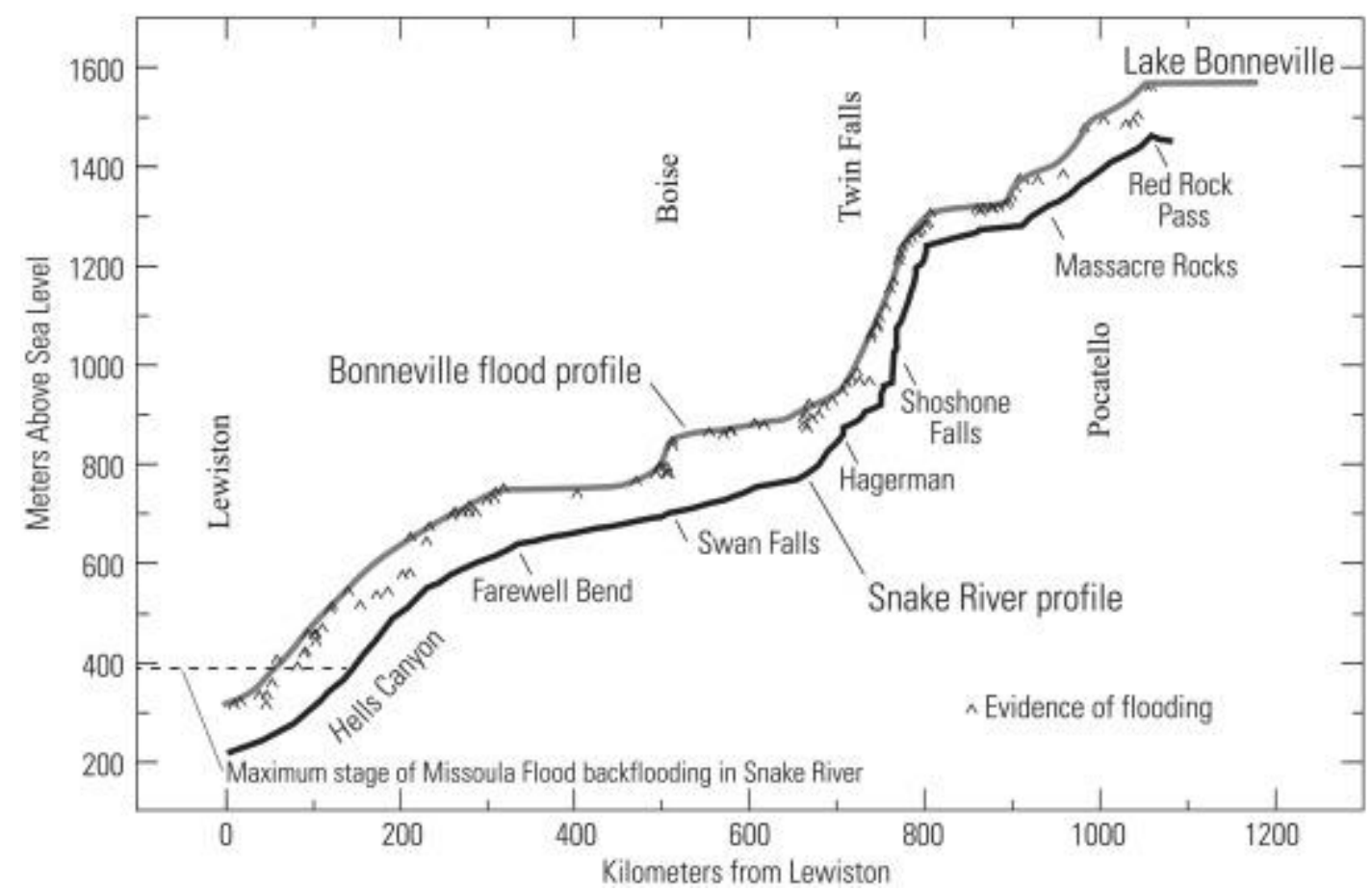


Figure 3
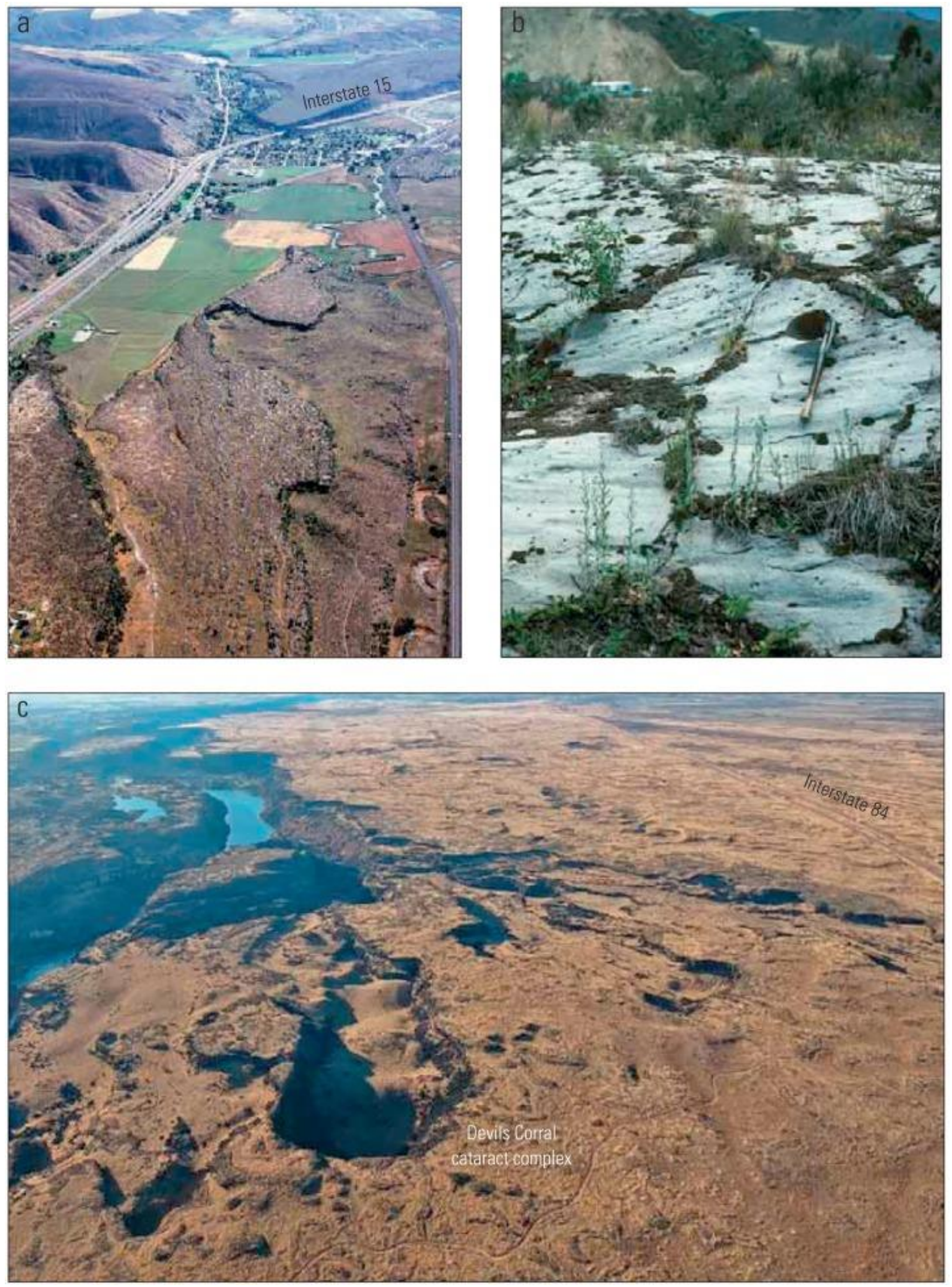
Figure 4
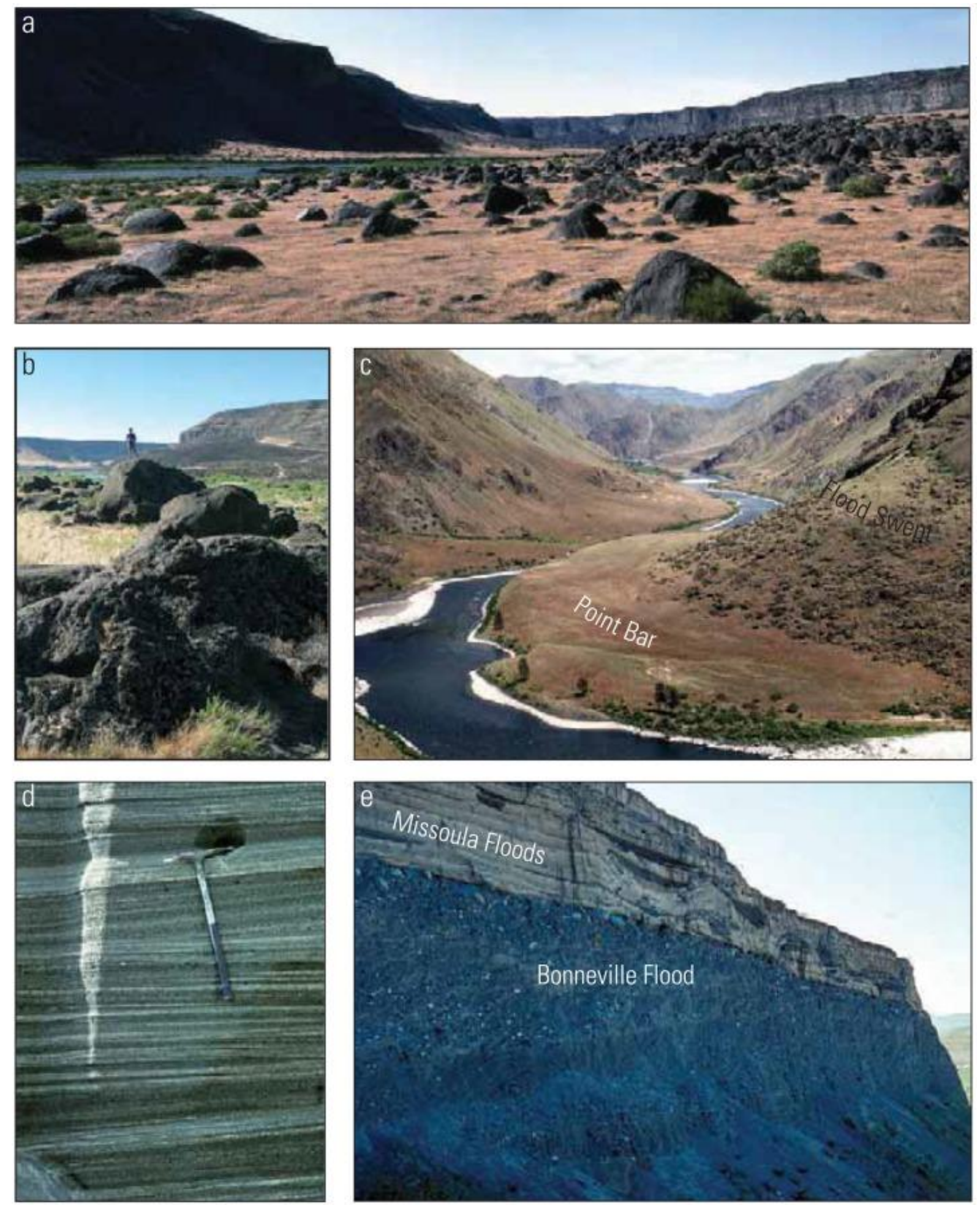
Figure 5

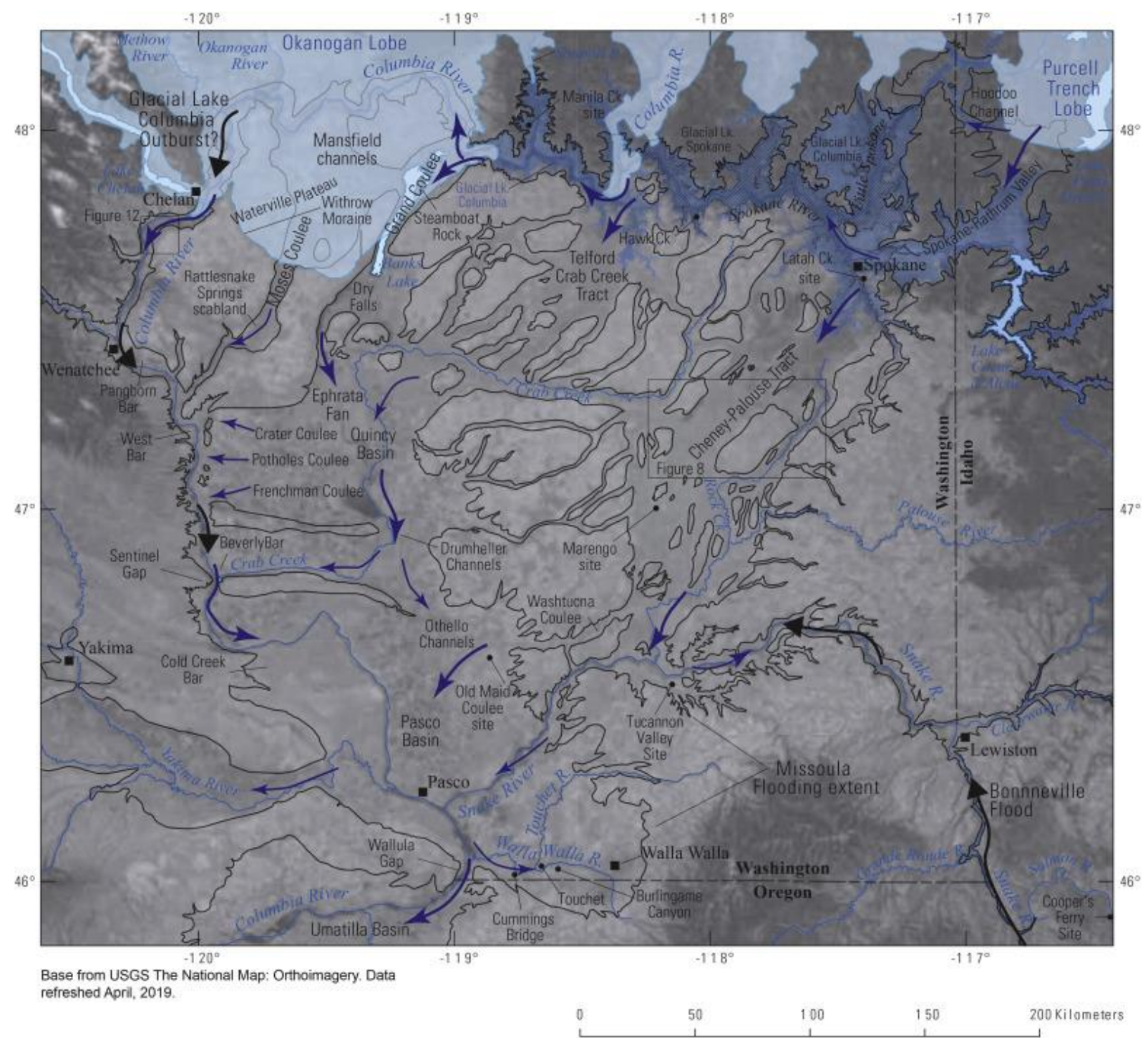


Figure 6
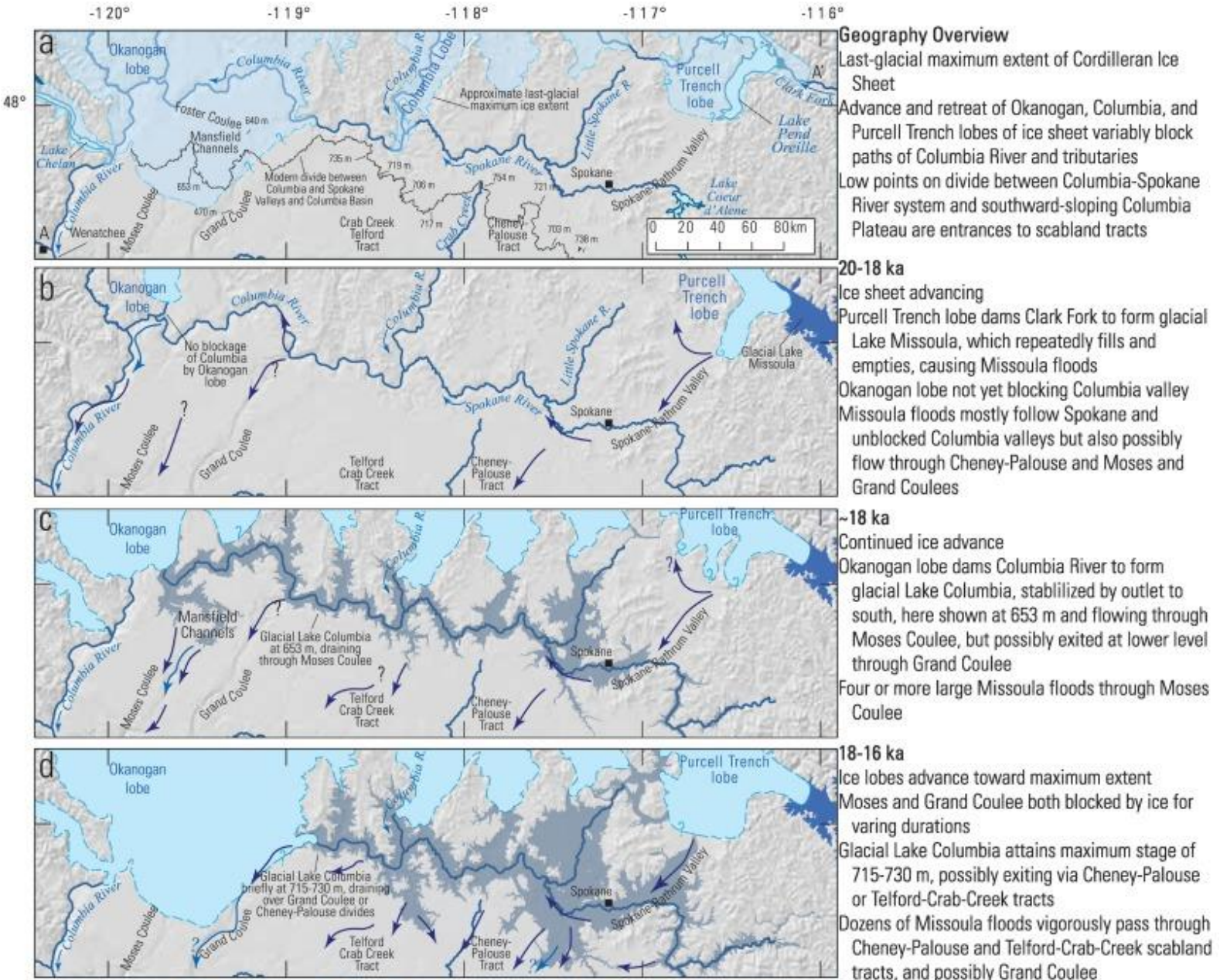

18-16 ka

Ice lobes advance toward maximum extent

Moses and Grand Coulee both blocked by ice for varing durations

Glacial Lake Columbia attains maximum stage of $715-730 \mathrm{~m}$, possibly exiting via Cheney-Palouse or Telford-Crab-Creek tracts

Dozens of Missoula floods vigorously pass through Cheney-Palouse and Telford-Crab-Creek scabland tracts, and possibly Grand Coulee

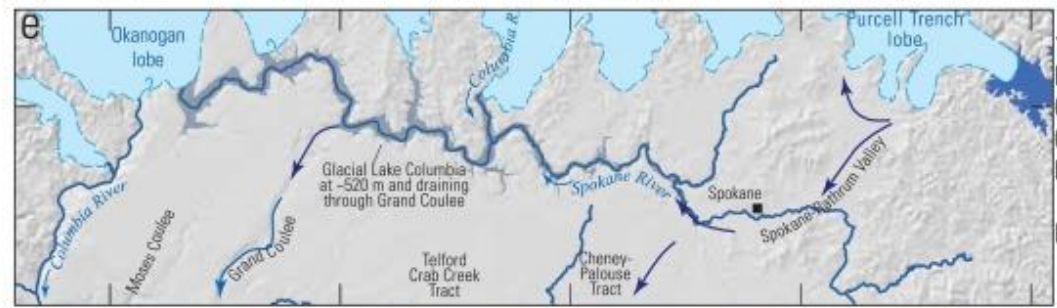

\section{6-15 ka}

Ice-sheet in retreat

Okanogan lobe still dams Columbia River Glacial Lake Columbia drains through Grand Coulee Dozens of Missoula floods through and possibly incising upper Grand Coulee

Floods also conveyed by Cheney-Palouse and possibly Telford-Crab-Creek tracts

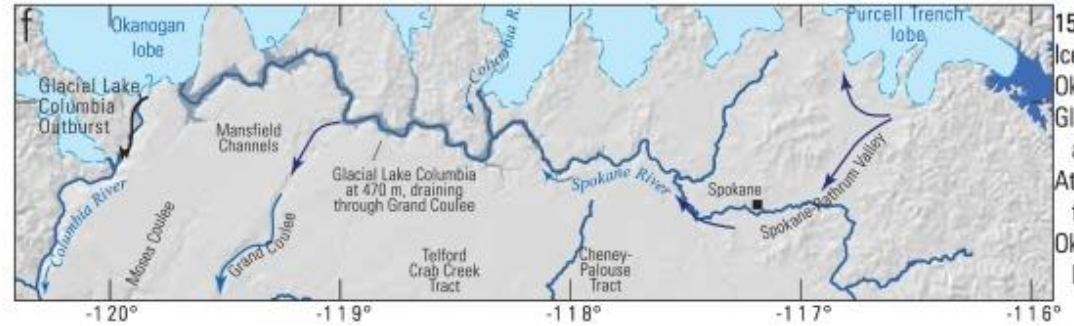

\section{5-14 ka}

Ice-sheet in retreat

Okanogan lobe still dams Columbia River

Glacial Lake Columbia drains through Grand Coulee at $470 \mathrm{~m}$ elevation

At least 13 final Missoula Floods possibly confined to Grand Coulee route

Okanogan lobe breaches and flood from glacial Lake Columbia follows Columbia River valley 
Figure 7
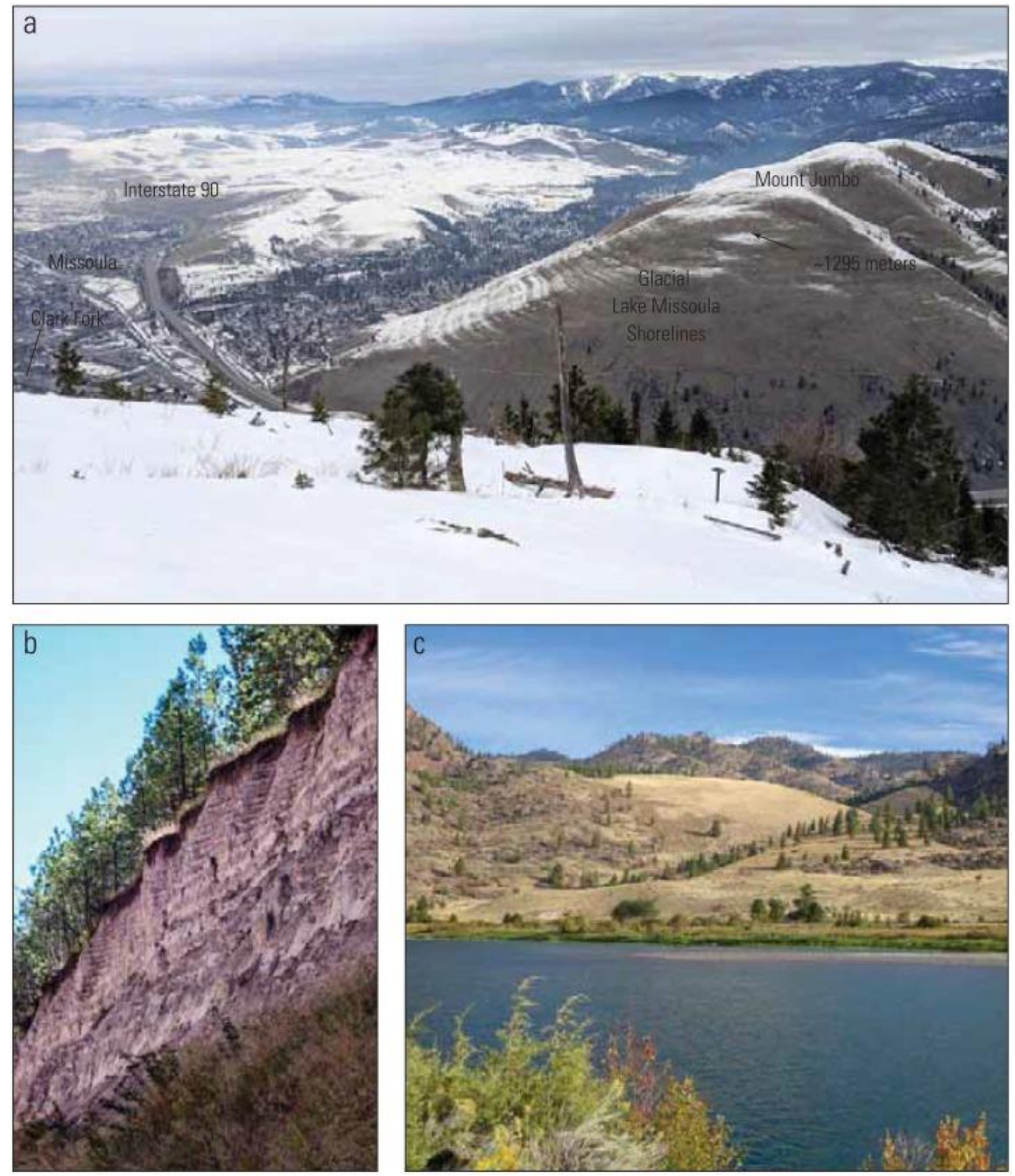
Figure 8

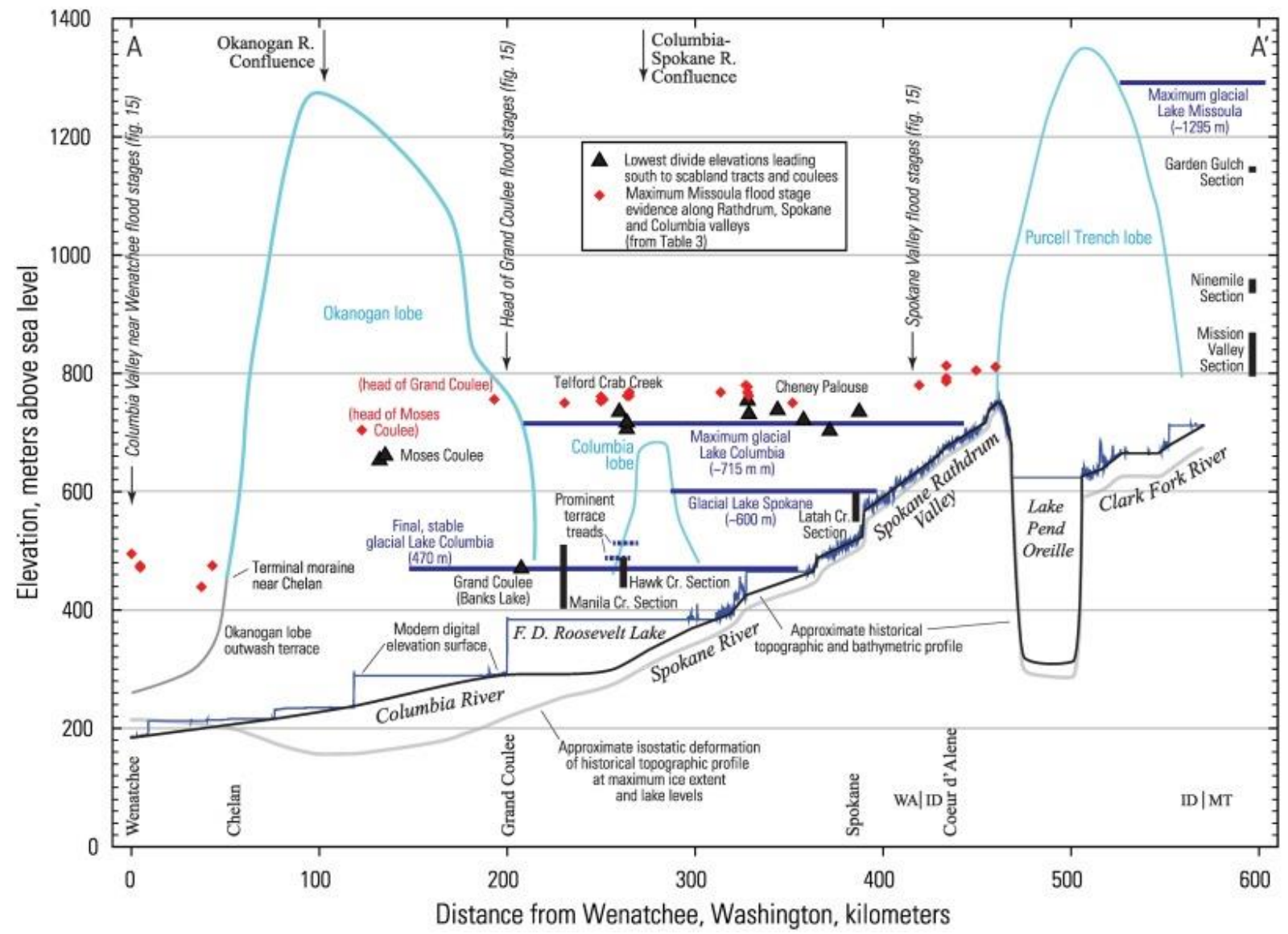

Figure 9

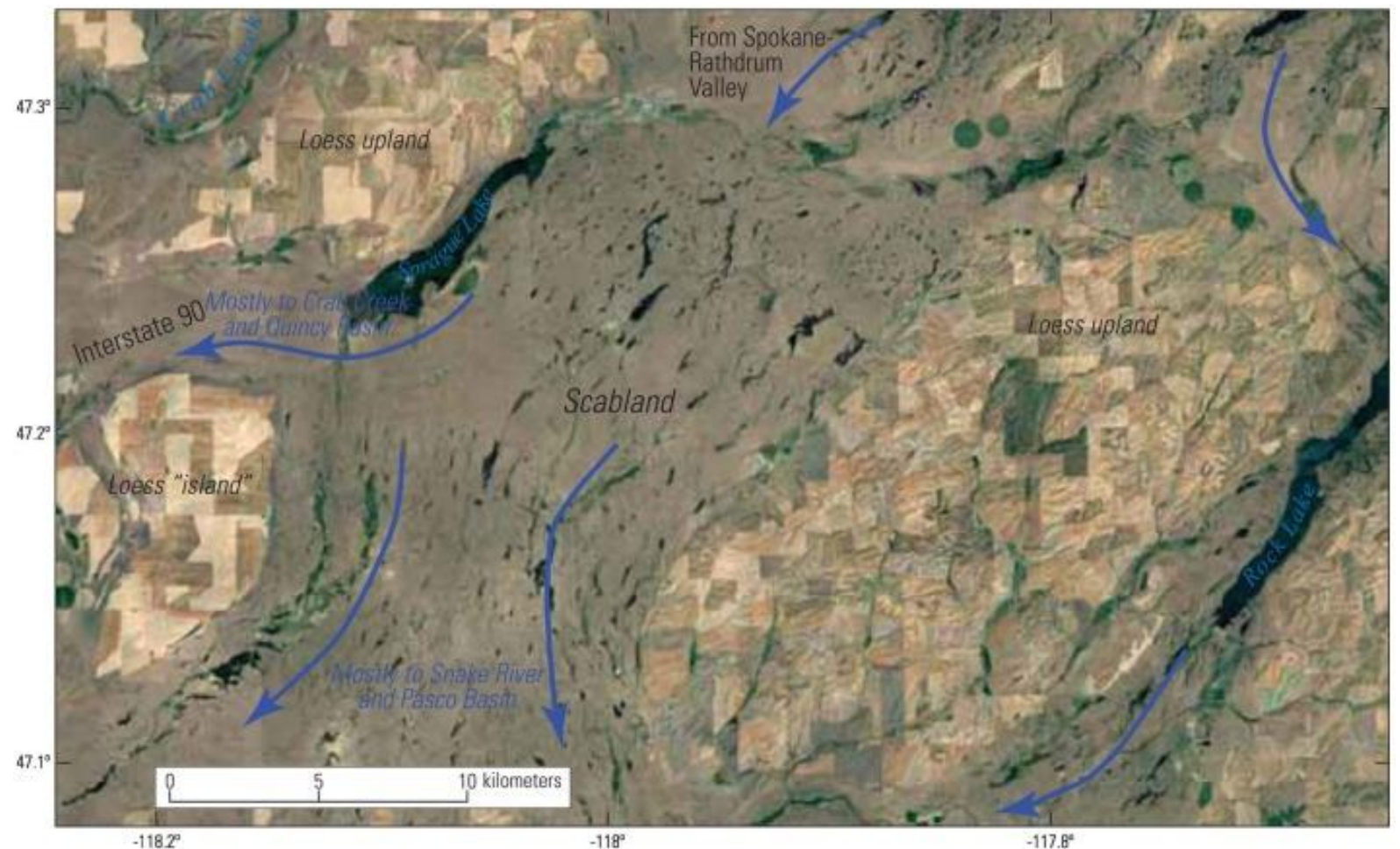


Figure 10

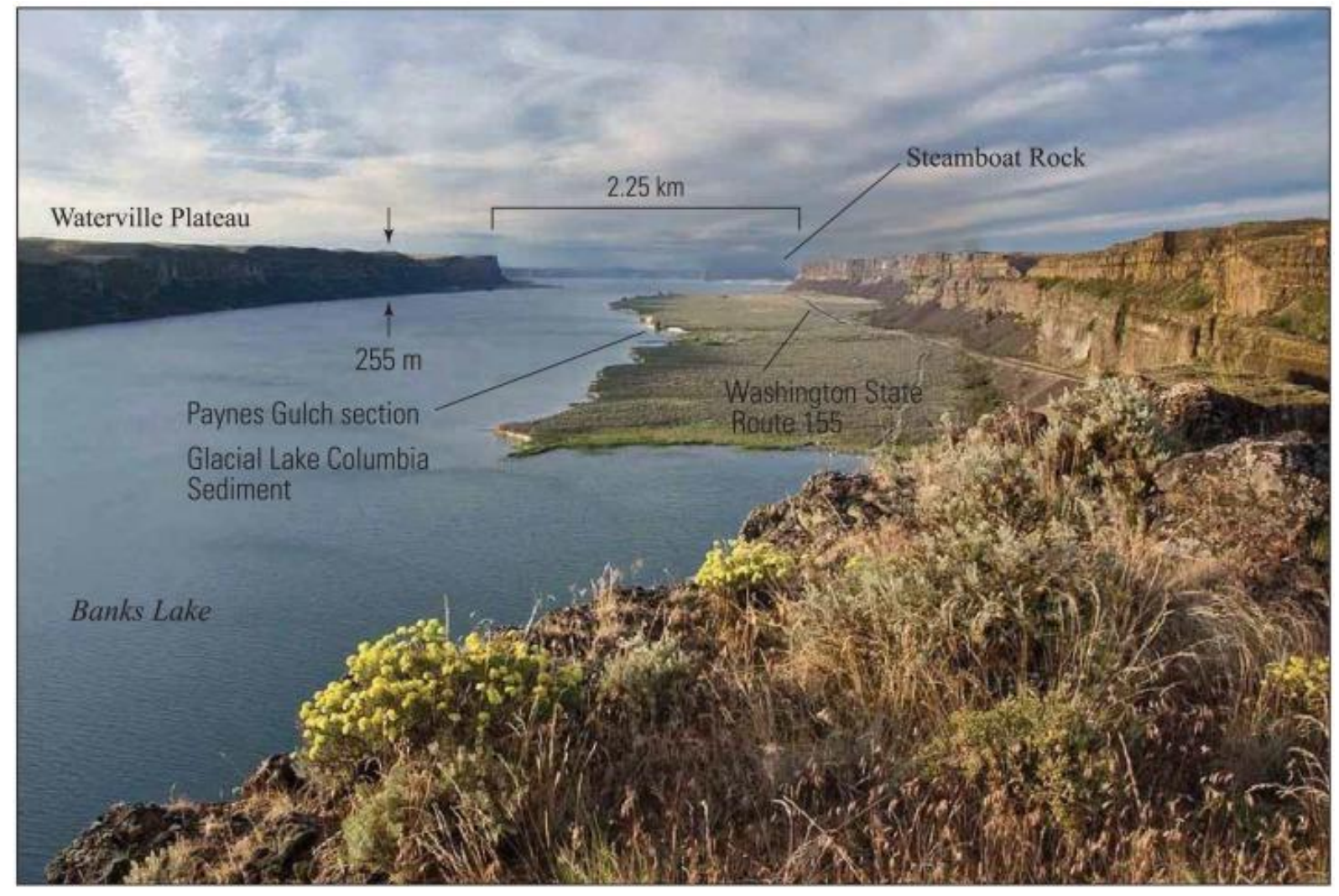

Figure 11

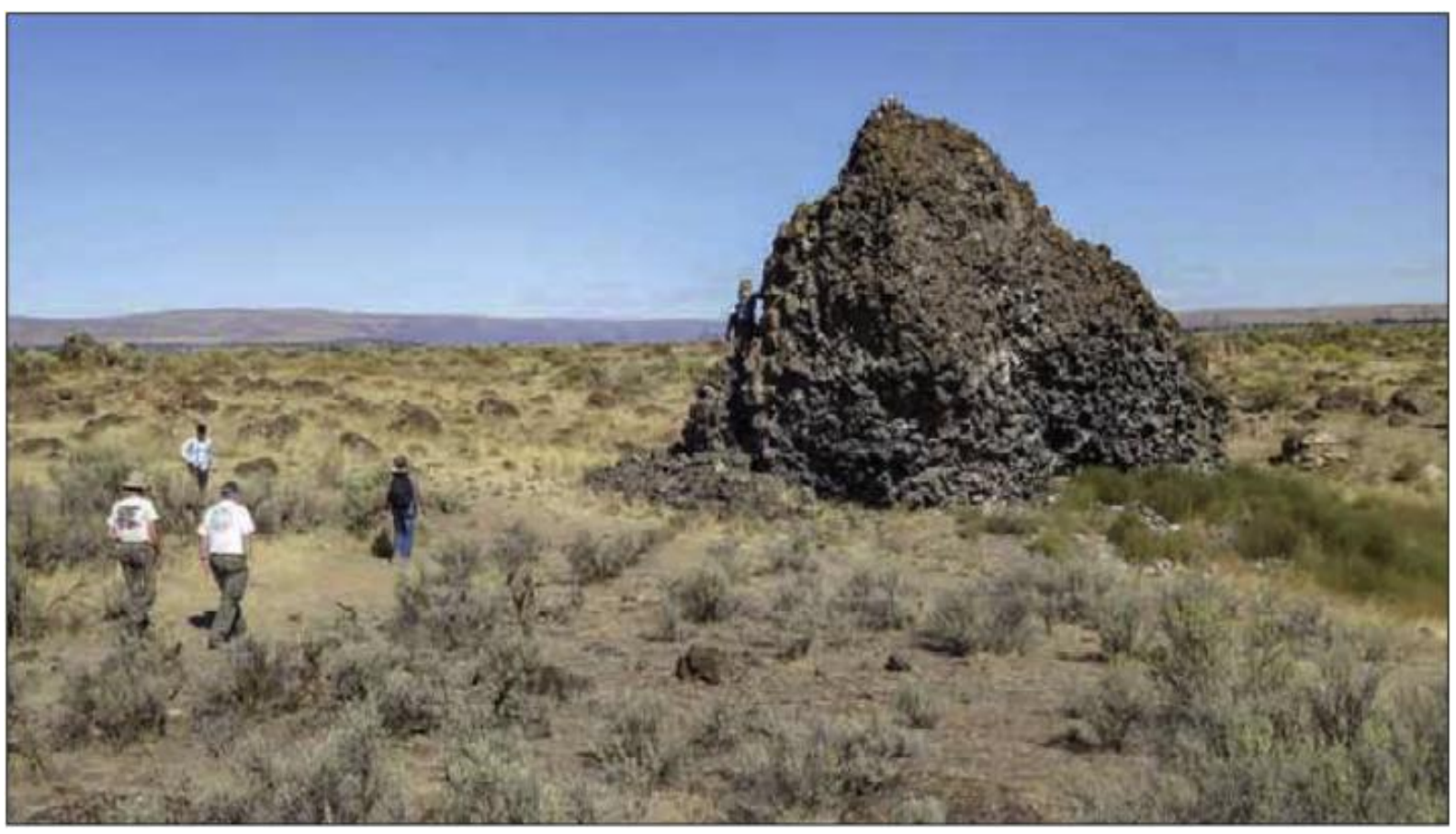




\section{Figure 12}

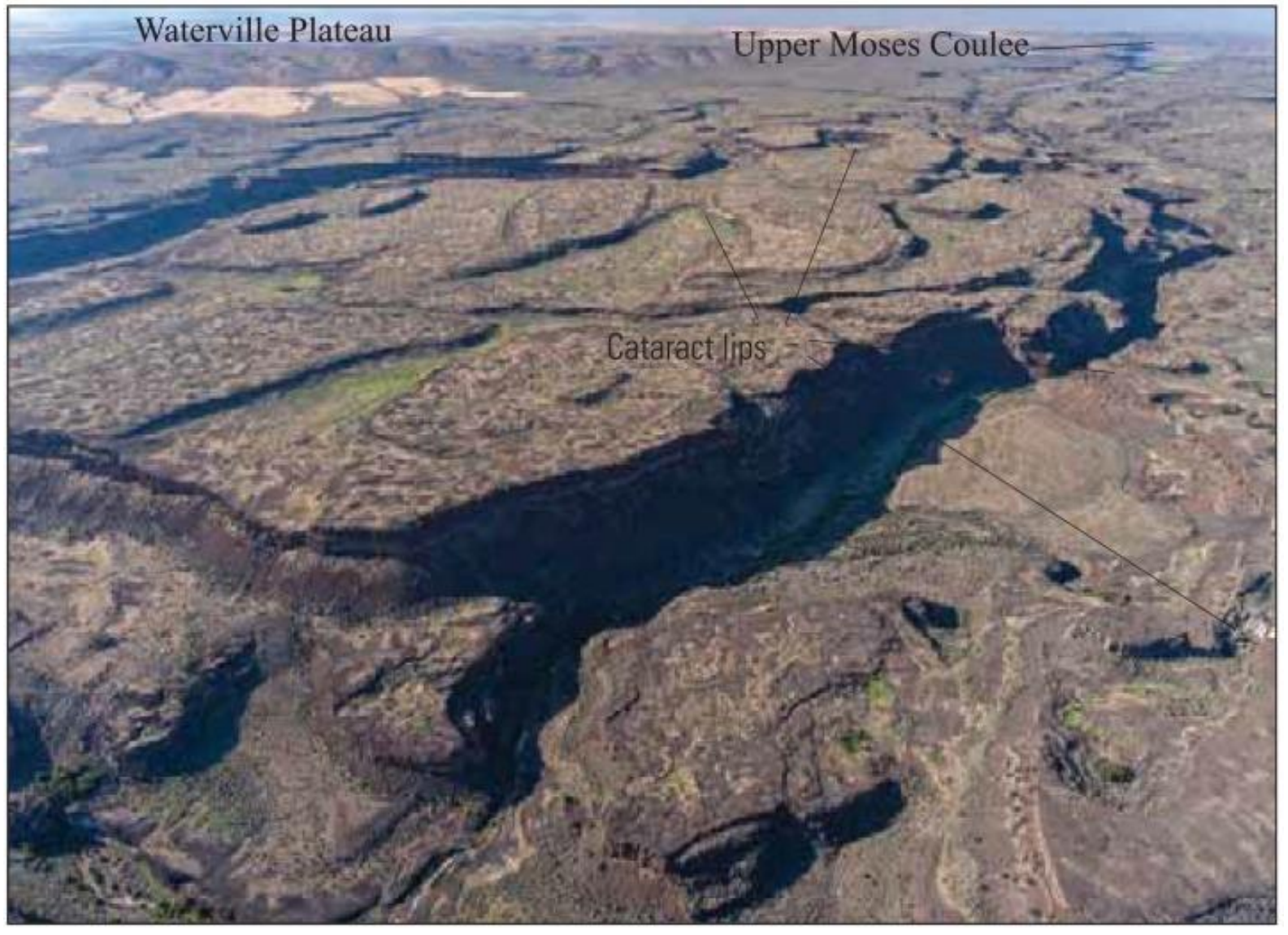


Figure 13

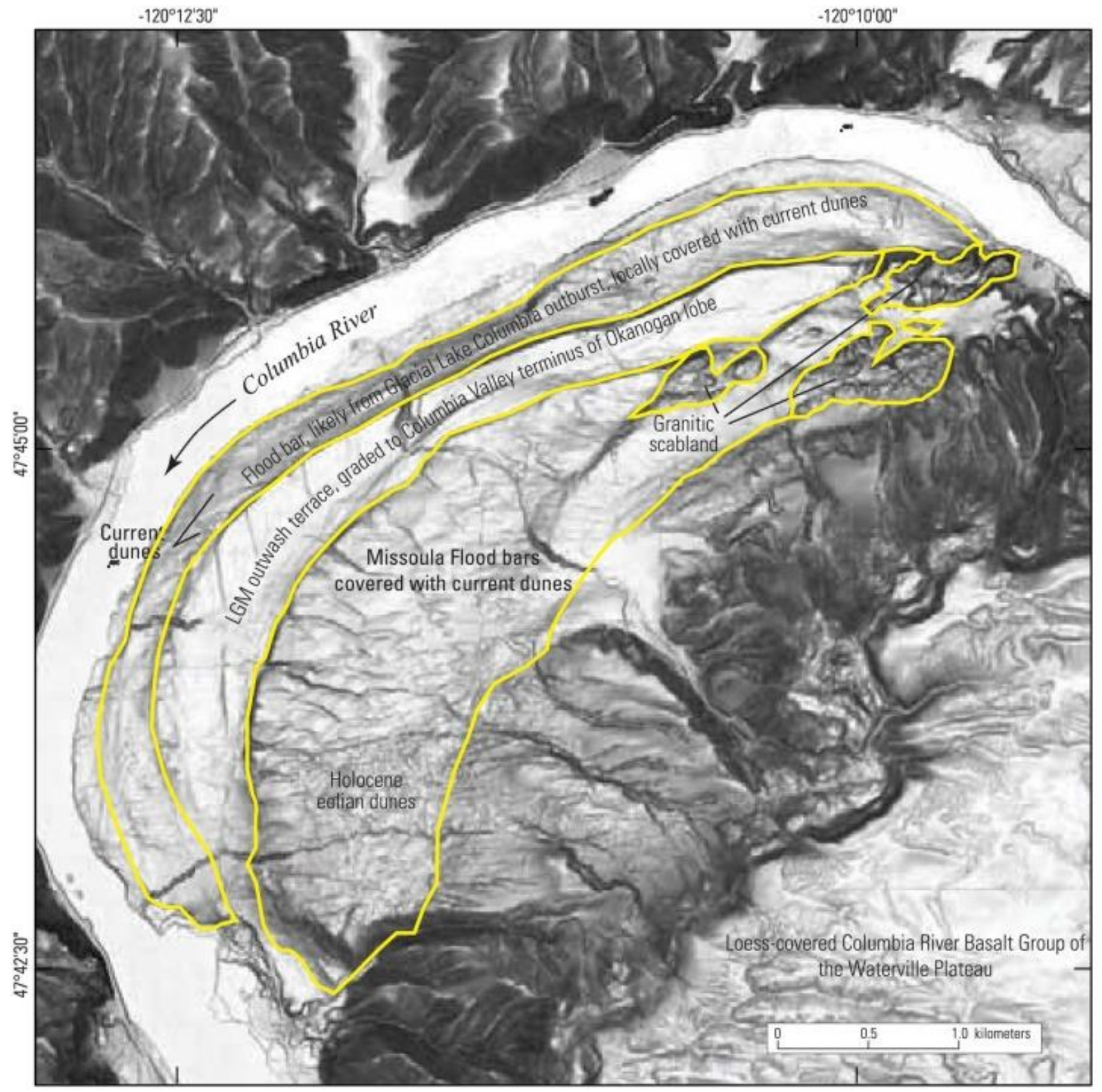


Figure 14

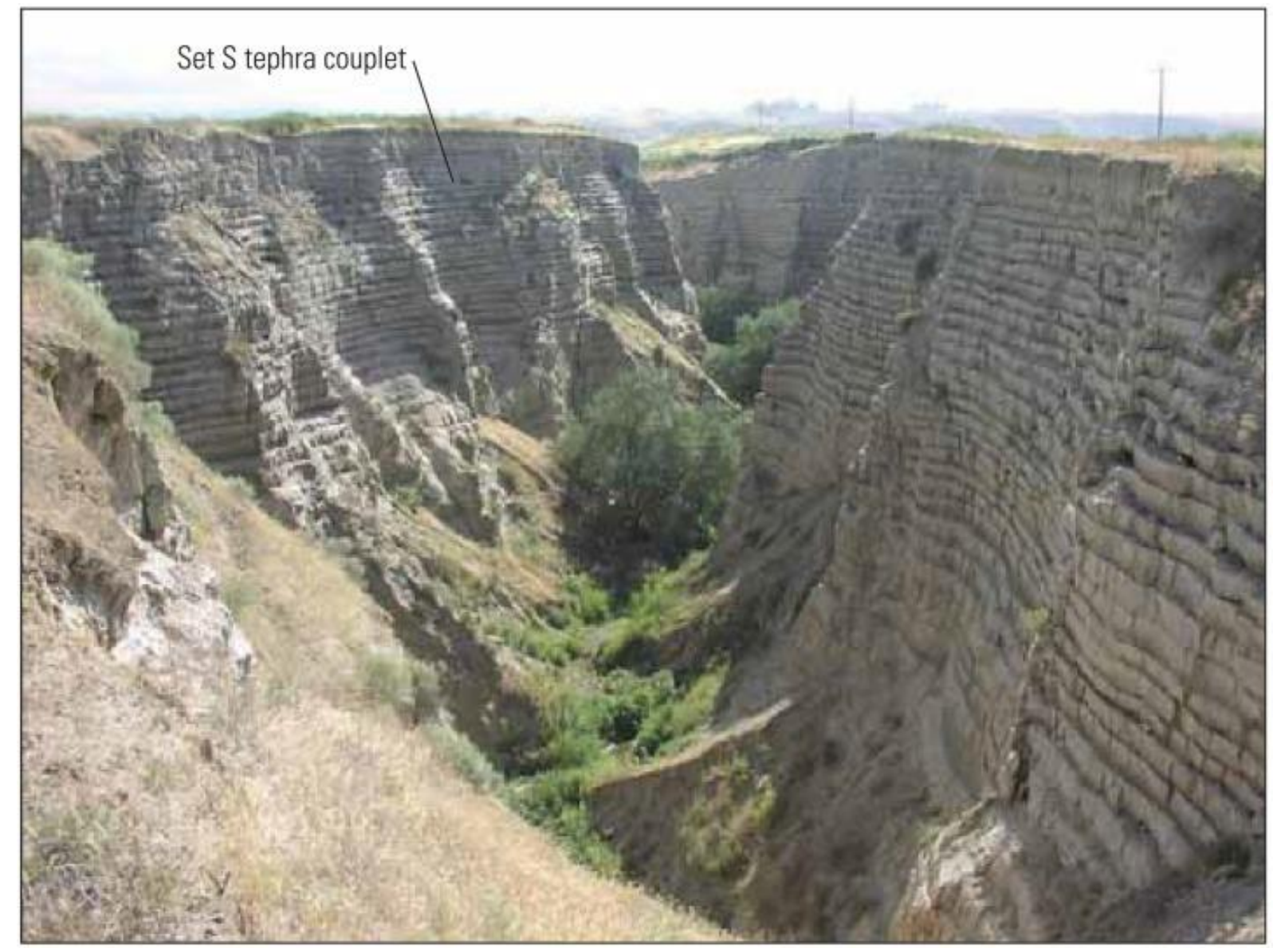




\section{Figure 15}

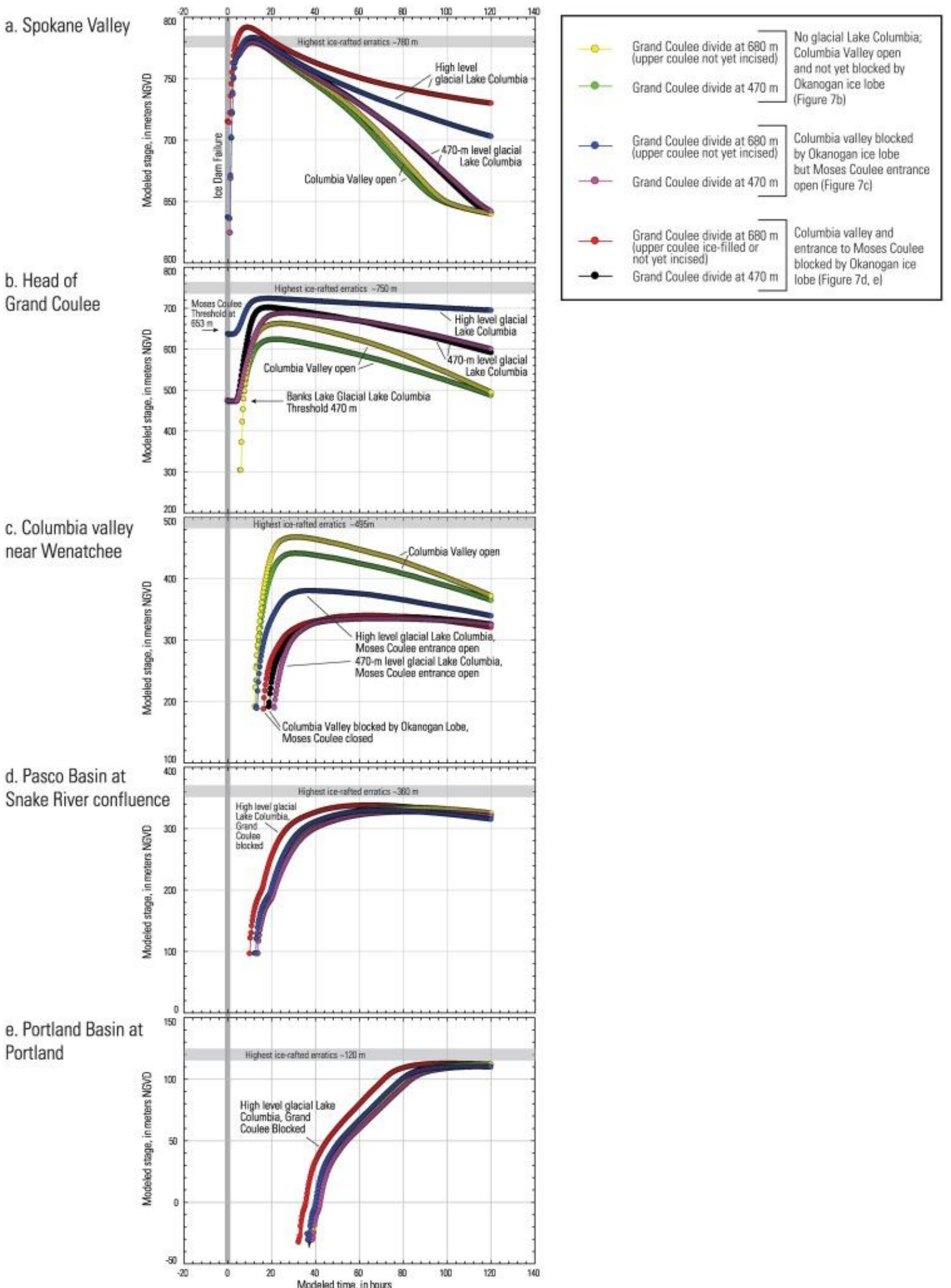




\section{Figure 16}
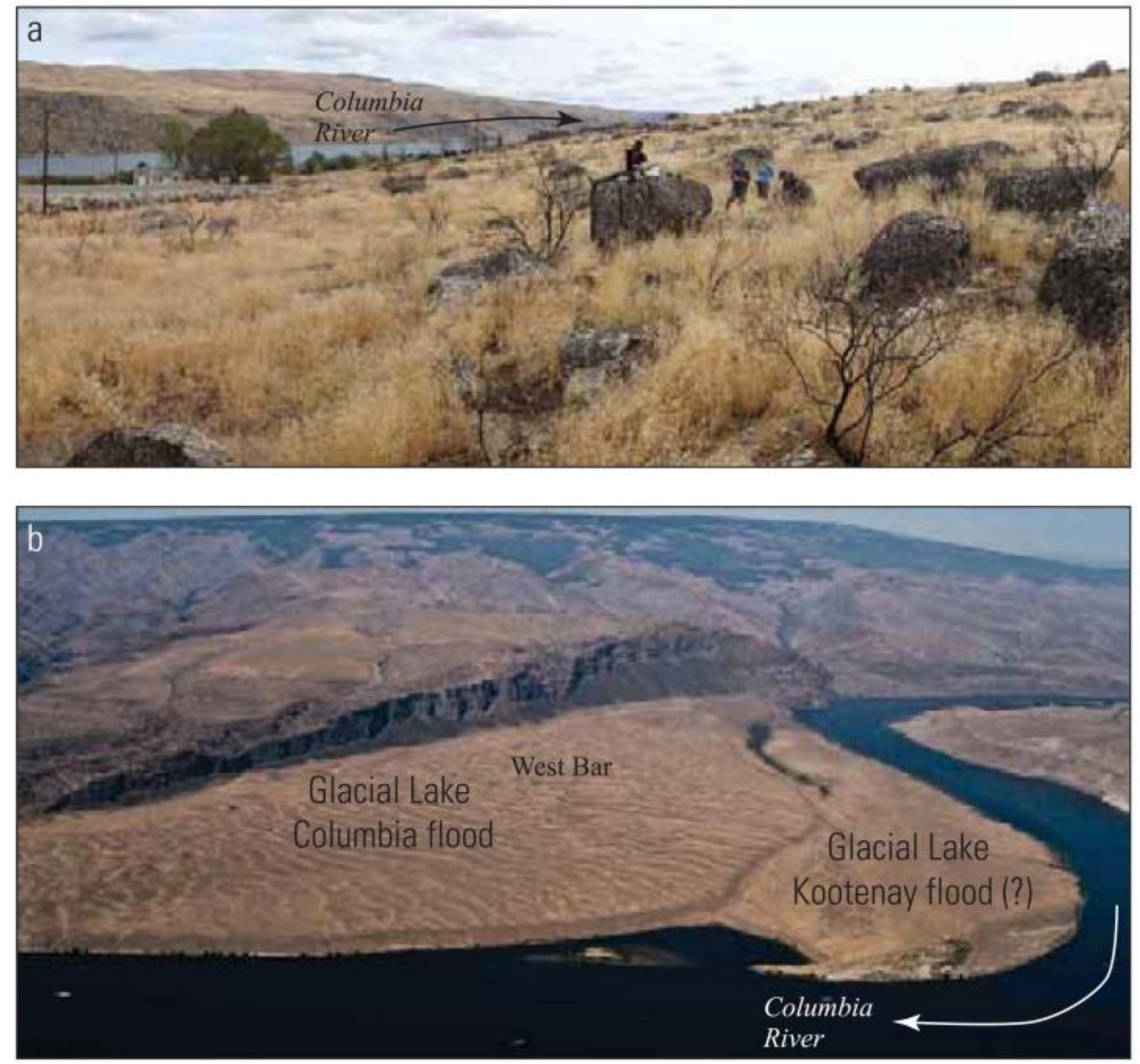


\section{Figure 17}
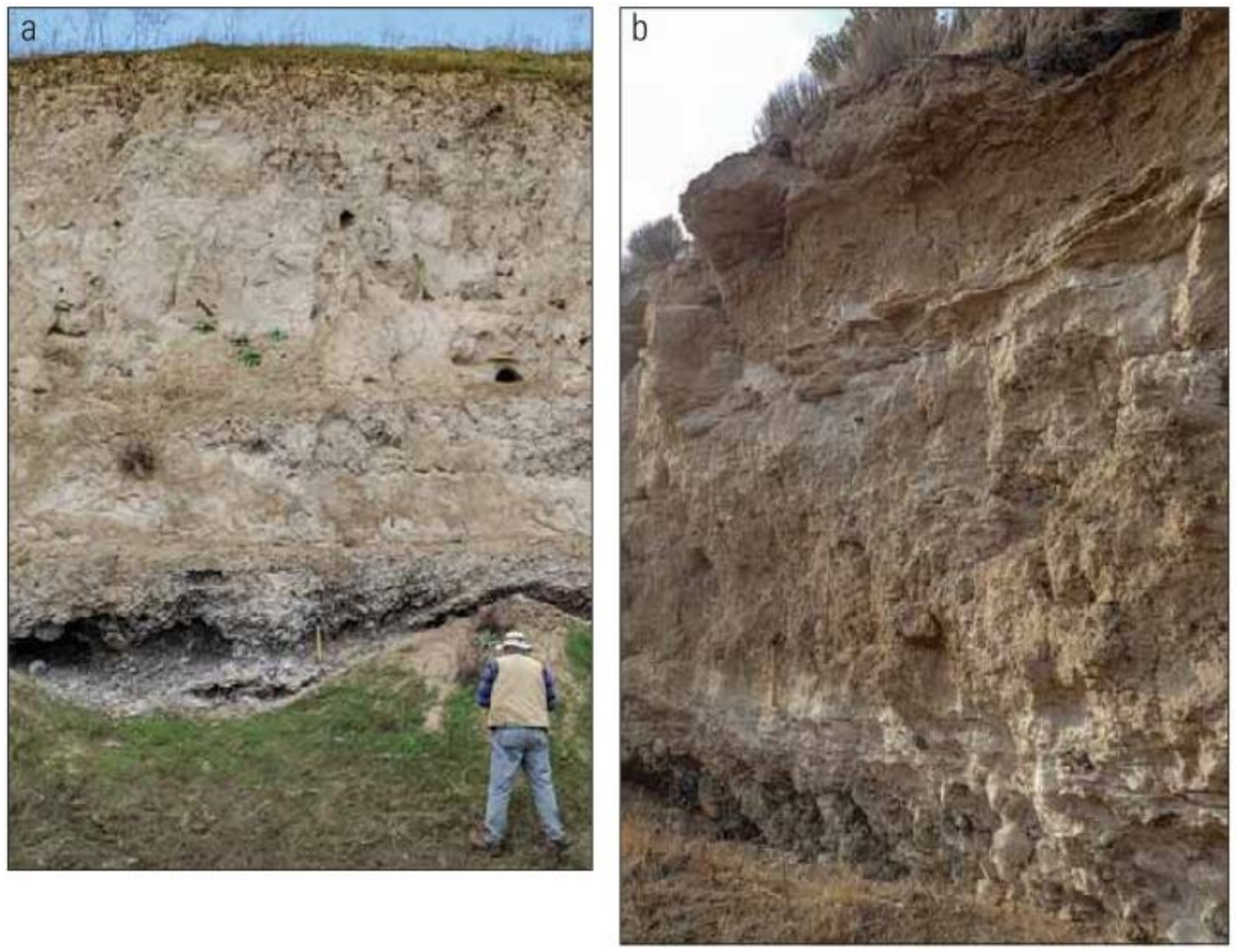